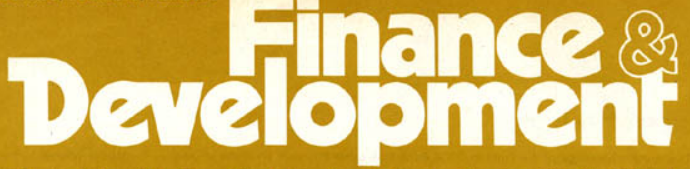

A quarterly publication of the International Monetary Fund and the World Bank

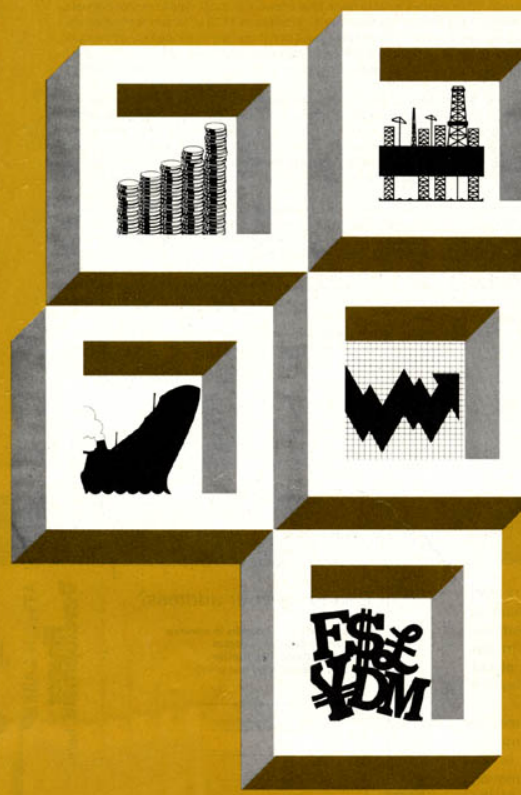

In this issue:

Bank-Fund annual meetings

Managing oil incomeIran, Saudi Arabia, Norway

External debt of developing countries

LDCs' access to capital markets IMF Trust Fund

Exchange rates and world trade The Bank: a financial appraisal Incomes policy and development 


\section{From the Editor}

The Annual Meetings of the Fund and the Bank took place this year amid the impressive hospitality offered by the Philippine Government and many of the people of Manila. Accounts of the proceedings there, by Mr. John Kay of the Fund and $\mathrm{Mr}$. $\mathrm{H}$-Joost Polak of the Bank, are included in this issue.

While, no doubt, as various commentators have remarked, the meetings left many issues both of development and of monetary management unresolved, constantly changing economic conditions in the world make such an outcome in broad terms inevitable, and likely always so to remain. What matters is not to reach final answers, but to find policies that alleviate continually changing points of friction or distress. The shock of the severe rise in prices in 1973 of certain raw materials. including oil, cast a long shadow over all economies. It is important to understand that there may be serious adjustments to be made even in those economies fortunate enough to be plentifully endowed with some raw material (oil in the cases of Iran, Saudi Arabia, and Norway). Their problems are examined in the articles by Messrs. Jakubiak and Dajani, and by Mr. Handler.

Such shocks may recur in the years to come, in one form or another. They have to be met, in a world of international finance, by gifts and loans, financed by surplus (and received by deficit) economies. But on what terms and conditions are these deliberately induced flows of purchasing power to take place? At what point do loans become so large as to impose a further unbearable hardship on the recipient country because of its obligation to repay? Such issues are fully discussed in the contributions of Messrs. Sturc, Klein, and Ahmad. There are various insights developed in these articles, which will perhaps make some of our readers more hopeful that the flow-of-capital problem-the transfer-of-resources problem-is not insoluble.

Mr. Rotberg has provided the second part of his study of the World Bank's finances, a subject especially topical in view of the related issue of capital increase for the Bank. Mr. Nowzad raises some questions about the effects of a fluctuating exchange rate system on world trade, and Mr. Bhatt considers the role of incomes policy in development planning.

The range of subjects covered in this issue is itself witness to the complexity of the problems that the world's institutions have to cope with, and bears out the point that there are not likely to be simple solutions. The marks of success are that economic growth continues, that maldistribution of wealth diminishes, that production as a whole increases, or that pollution is here and there brought under control, and it is from signs such as these that we get to know whether or not our international institutions are working in fruitful directions.

The editors intend to publish extracts of available statistics from time to time to emphasize such progress as is measurable. Several examples may be found in this issue based on current research in both the Bank and the Fund.

We would like to thank all readers who completed and returned the readership survey questionnaires sent to them recently. The survey will assist us in our future work. Only a small sample of our readers were polled for this survey but the response has been gratifying.

In the near future ALL READERS may be asked to provide some basic information about their professional interest in Finance \& Development. This information is essential for the management of the magazine and we would appreciate your prompt cooperation when you receive such a request.

\section{Changing your address?}

Please notify us 2 months in advance in order to keep your copies arriving without interruption. My new address is (please print):

\begin{tabular}{l}
$\overline{\text { Name }}$ \\
\hline Address \\
$\overline{\text { City }}$ \\
Country \\
Place in envelope, \\
stamp, and mail to: \\
Finance \& Development \\
International Monetary Fund BIdg. \\
Washington, D.C., 20431, U.S.A.
\end{tabular}




\section{Developingent}

Editor

Ian Bowen

Deputy Editor

Shuja Nawaz Joslin Landell-Mills

Editorial Assistant

Marjorie H. Antonoff

Art Editor

Richard W. Stoddard
Assistant to the Editor
Consulting Editor L. Rubén Azócar

Advisors to the Editor Dinesh Bahl

Barend $A$. de Vries Norman K. Humphreys John A. King

Carlos E. Sansón Eugene R. Schlesinger Charles F. Schwartz U Tun Wai

David Williams
Finance \& Development is published quarterly in English, French, and Spanish by the International Monetary Fund and the International Bank for Reconstruction and Development, Washington, D.C. 20431, U.S.A

A German language edition is published by the International Monetary Fund and the International Bank for Reconstruction and Development in collaboration with HWWA-Institut für Wirtschafts forschung-Hamburg, and produced by Verlag Weltarchiv $\mathrm{GmbH}$.

Readers wishing to receive the German edition should write directly to Finanzierung \& Entwicklung HWWA-Institut, 2 Hamburg 36, Neuer Jungfernstieg 21, Germany

A selection of articles from each issue is published in Arabic and issued as a supplement to Al-lqtissadi. c/o Al-Ahram, Cairo, Egypt. Individual copies of this selection are also available on application to The Editor, Finance \& Development, International Monetary Fund Building. Washington, D.C. 20431, U.S.A

A selection of the contents of Finance \& Deve/. opment is published annually in Rio de Janeiro, Brazil, in cooperation with the United Nations Information Center, in Portuguese.

Controlled circulation postage is paid at Washington, D.C. and Lancaster, Pa., U.S.A

New readers who wish to receive Finance $\&$ Development regularly may make an application through an appropriate institution, or individually, to be added to the mailing list. Individuals should briefly state the reasons for their request. Please indicate which language edition is wanted-only one edition will be sent. Applications should be mailed to Finance \& Development, International M onetary Fund Building, Washington, D.C.. 20431, U.S.A.

Opinions expressed in articles and other material are those of the writer or writers: they are not statements of Fund or Bank policy.

The contents of Finance \& Development may be quoted or reproduced without further permission. Due acknowledgment is requested.

Finance \& Development is available on microfilm from University Microfilms, P.O. Box 1346. Ann Arbor, Michigan 48106, U.S.A and on microfiche (English only) from Microphoto Division, Bell and Howell Company, Old Mansfield Road, Wooster, Ohio 44691. U.S.A.
Volume 13 / Number 4/December 1976

\section{Bank activity}

Bank and IDA projects in Kenya, Cameroon, and Malaysia; cost of

\title{
Fund activity
}

More gold auctions; Interim Committee meeting: Fund history 1966-71 prepared: developments in the world economy, a selection

\section{The problems of monetary management}

\author{
John A. Kay
}

$A^{\prime}$ report on the Fund Annual Meeting

\section{Challenging human poverty}

$H$-Joost Polak

A report on the Bank Annual Meeting

\section{Oil income and financial policies in Iran and Saudi}

\section{Arabia}

Henry E. Jakubiak and M. Taher Dajani

Managing increased oil sector revenues in two developing economies

\section{Oil revenues - their implications for an industrial economy}

Heinz Handler

How Norway is coping with the flow of North Sea oil money

The external debt situation of developing countries

Thomas M. Klein

An assessment based on the Bank's World Debt Tables

\section{The developing countries and access to capital markets}

M.M. Ahmad

An analysis, and suggestions for making such access easier

\section{The Trust Fund}

Ernest Sturc

Balance of payments assistance for LDCs financed by profits of the

Fund's gold sales-an explanation

Fluctuating exchange rates and world trade

Bahram Nowzad

The need for greater coordination of the reform effort in these two

related areas

\section{The World Bank-a financial appraisal: II}

Eugene H. Rotberg

Lending policies, creditworthiness of borrowers, project appraisal,

\section{Incomes policy and development planning}

\section{V.V. Bhatt}

An analysis of their relationship, and the role of incomes policy in the 


\section{World Bank and IDA lend $\$ 45$ million to Kenya}

The World Bank and its affiliate, the International Development Association (IDA), will support three projects in Kenya-one for rural access roads, another for integrated rural development, and $a$ third for wildlife and tourism.

A \$4 million loan and a \$4 million IDA credit will assist the Government of Kenya in implementing the first phase of the rural access roads program. The program aims at the construction of 15,000 kilometers of rural access roads in eight years. Its main objectives include stimulating increased cash crop and livestock production and bringing more farmers into the market economy by providing the necessary allweather access to markets. The project will provide rural employment by using labor-intensive construction methods and will improve access to social facilities and services as well as increase local participation.

The Bank loan is for a term of $\mathbf{2 5}$ years with 5 years of grace and interest at $\mathbf{8 . 8 5}$ per cent per annum. The IDA credit is on standard IDA terms-for 50 years, including 10 years of grace, interest-free but carrying a service charge of $3 / 4$ of 1 per cent to cover IDA's administrative costs.

An integrated agricultural development project will constitute the first phase of an integrated agricultural development program for the development of smallholder agriculture in Kenya. It will promote the establishment of whole farm systems through the provision of tools, seeds, fertilizers, and other farm implements. It will also strengthen extension services and institutions to meet the needs and support required for a wide range of crop and livestock activities in four of Kenya's provinces.

The project is expected to encourage the production of maize, beans, cotton, potatoes, passion fruit, oilseeds, meat, and milk by about 70,000 small farmers operating some 56,000 holdings. It represents the first major effort in Kenya to benefit smal! farmers. It will revitalize the institutions supplying services to those farmers and focus attention directly on their problems.

This project is to receive a $\$ 10$ million Bank loan on Third Window terms, namely, for 25 years, including 7 years of grace, and carrying interest at 4.85 per cent per annum. An additional 4 per cent will be paid to the Bank by the Interest Subsidy
Fund, representing the difference between the Bank's standard rate and the charge to the borrower. The IDA credit is also for $\$ 10$ million. The Arab Bank for African Development is cofinancing the project with a loan of $\$ 5$ million for 25 years, including 5 years of grace, at 4 per cent interest per annum.

The third project aims to support the Kenyan Government in implementing its policies on the conservation of wildlife resources and development of tourist

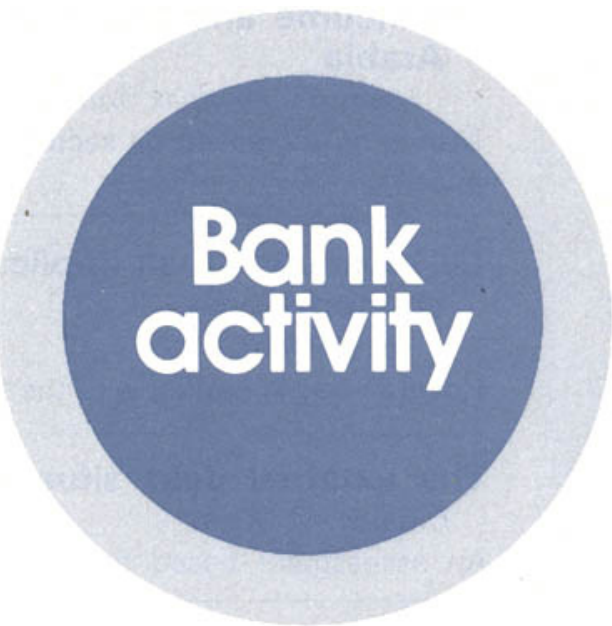

Kenya: some basic data

Total land area

(thousand square $\mathrm{km}$ )

582.6

Most recent estimate

GNP per capita (US\$)

Population

(mid-year, millions)

Total population growth rate (per cent)

Total labor force (thousands)

Labor force in agriculture (per cent)

$\begin{array}{rrr}1970 & \begin{array}{c}\text { Most recent } \\ \text { estimate }\end{array} \\ 140.0 & & 220.0 \\ 11.2 & & 13.3 \\ 3.1 & & 3.5\end{array}$

$5,100.0^{a} \quad 5,400.0^{b}$

$90.0^{\mathrm{a}} \quad 86.0^{\mathrm{b}}$

a/ Labor force age: $15-59$ years. b/ 1971 .

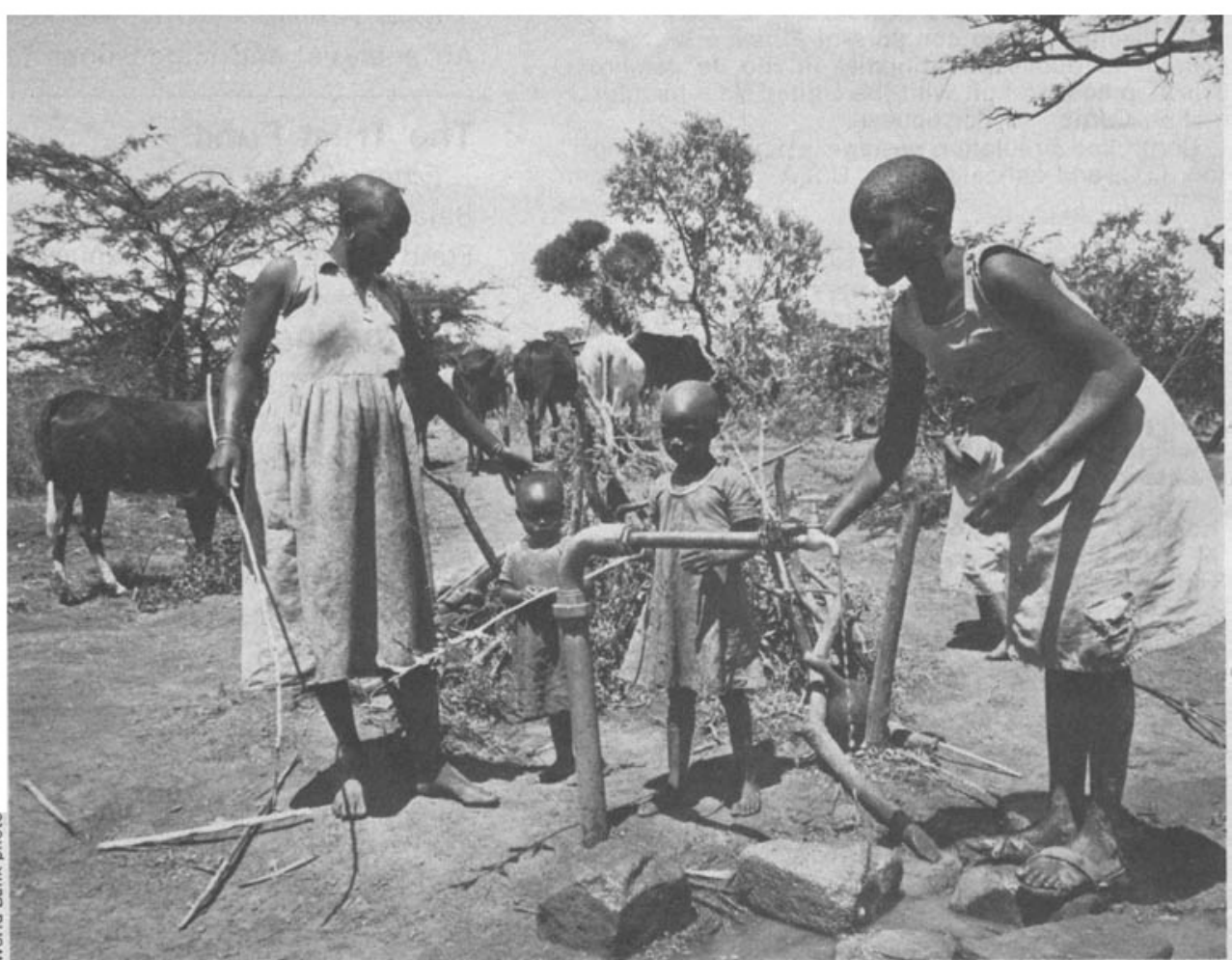


attractions. It will improve tourist facilities in several important parks and reserves throughout the country. The project will also help finance a Wildlife and Fisheries Training Institute, buses for the Wildlife Clubs of Kenya, and support for antipoaching activities. One objective of this project is to increase the impact of tourism on the overall development of the economy with specific emphasis on rural incomes. It will support more thorough planning and wildlife development and provide training facilities in wildlife conservation and management.

The Bank will support this project with a $\$ 17$ million loan on Third Window terms.
IDA credits during first quarter of fiscal 1977

(Ended September 30, 1976)

\begin{tabular}{|c|c|c|}
\hline Country & Purpose & $\begin{array}{l}\text { Amount } \\
\text { ons of U.S. dollars) }\end{array}$ \\
\hline Cameroon & Ports & $10.0^{\mathrm{a}}$ \\
\hline Chad & Irrigation & 8.0 \\
\hline Kenya (2) & Agriculture, rural roads & $14.0^{b}$ \\
\hline Nepal (2) & Irrigation, technical assistance & 12.0 \\
\hline Rwanda (2) & Development finance company, Cínchona & 5.8 \\
\hline Tanzania (2) & Fisheries, tobacco processing & 17.0 \\
\hline Tunisia & Population (supplementary) & 4.8 \\
\hline Upper Volta & Highways & 20.0 \\
\hline Zaïre & Cotton & 8.0 \\
\hline Total & & 99.6 \\
\hline
\end{tabular}

\section{Second Cameroon port project gets aid; Chad, Central African Republic to benefit too}

The first Douala Port Project, which received an International Development Association (IDA) credit of $\$ 1.5$ million in 1971, was satisfactorily completed in 1974; now both the World Bank and IDA will support the Second Douala Port Project in Cameroon by providing a loan and a credit totaling $\mathbf{\$ 2 5}$ million.

The $\$ 15$ million Bank loan is for a term of 20 years including $4 \frac{1}{2}$ years of grace and interest at $\mathbf{8 . 9}$ per cent per annum. The proceeds of the $\$ 10$ million IDA credit will be relent to the National Ports Authority on terms and conditions similar to those of the Bank loan.

Douala is Cameroon's major economic center. Its location on the Gulf of Guinea makes it a vital gateway for the country's exports and imports as well as for those of its landlocked neighbors, Chad and the Central African Republic. The main elements comprising the Second Douala Port Project are: (1) upstream port development, including cold storage and market facilities, a new dockyard, a floating dry dock, and new fishing berths; (2) downstream port development, including an area for handling logs, three moorings for log-carrying vessels, a berth for containers and general cargo, and a transit shed; (3)dredging of the entrance channel; (4) road and rail access and other port improvements; and (5) consulting services for supervision of construction.

In addition to increasing the timber export potential and the development of the forestry sector in Cameroon, the project is expected to increase Douala's import and export capacity. Provision of both fresh and frozen fish, an important part of the Cameroonian diet, will be improved through the development of fishing berths. Avoidance of port congestion, reduction in delays to shipping caused by the limited channel depth, and the introduction of specialized log carriers

\begin{tabular}{|c|c|c|}
\hline \multicolumn{3}{|c|}{ Cameroon: some basic data } \\
\hline \multirow[t]{2}{*}{$\begin{array}{l}\text { Total land area } \\
\text { (thousand square } \mathrm{km} \text { ) }\end{array}$} & \multicolumn{2}{|r|}{475.4} \\
\hline & 1970 & $\begin{array}{l}\text { Most recent } \\
\text { estimate }\end{array}$ \\
\hline GNP per capita (US\$) & 230.0 & 330.0 \\
\hline $\begin{array}{l}\text { Population } \\
\text { (mid-year, millions) }\end{array}$ & 5.8 & 6.5 \\
\hline Population density: & & \\
\hline Per square km & 12.0 & 14.0 \\
\hline $\begin{array}{l}\text { Per square km agricul- } \\
\text { tural land }\end{array}$ & 37.0 & $\ldots$ \\
\hline $\begin{array}{l}\text { Total population growth } \\
\text { rate (per cent) }\end{array}$ & 2.0 & 2.0 \\
\hline indicates data not available. & & \\
\hline
\end{tabular}

now unable to use the port are among the benefits of this project.

The African Development Bank, the Arab Bank for Economic Development in Africa, the Kreditanstalt für Wiederaufbau, the European Economic Community, and the Canadian and French aid agencies will participate in the financing of the project with loans and grants amounting to about $\$ 71$ million.
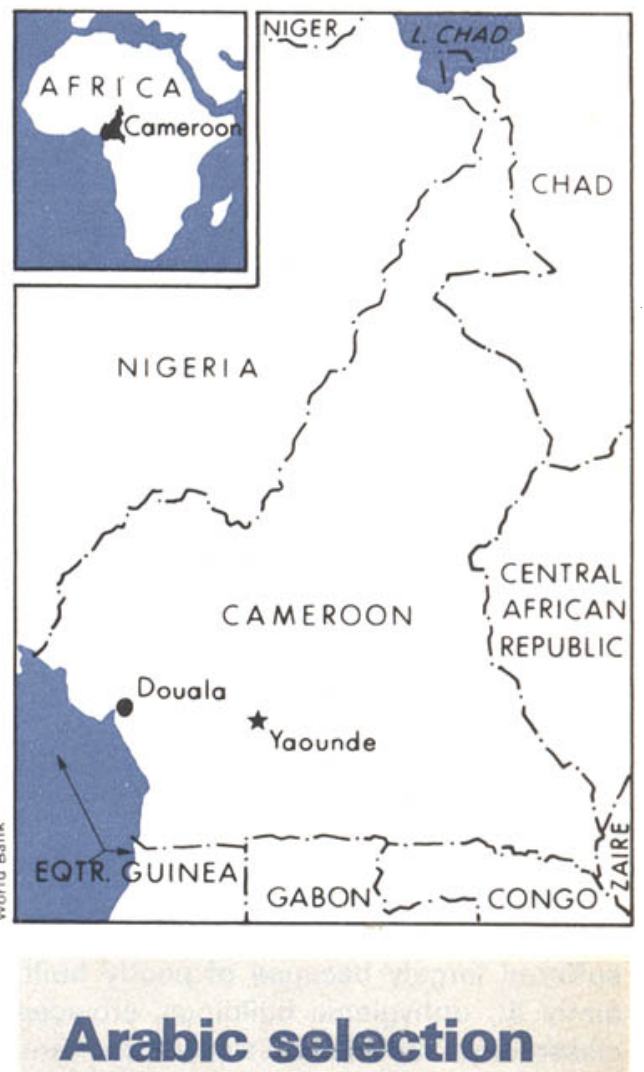

A digest-size selection of articles from Finance \& Development is now available in Arabic. Readers who wish to receive the Arabic selection should send their current address label and include their address in Arabic. New readers may also send their requests to

The Editor

Finance \& Development

International Monetary Fund Building Washington, D.C. 20431 


\section{Primary and vocational education aid for Malaysia}

Malaysia's primary school education and industrial manpower training capacity will be expanded and improved with the help of a World Bank loan of $\$ 35$ million for an education project.

The Bank loan is for 17 years, including $31 / 2$ years of grace, with interest at 8.9 per cent per annum.

This fourth Bank loan for Malaysian education will support the Government's five-year primary school construction program in seven of the country's poorest states: Kedah, Kelantan, Pahang, Perak, Sabah, Sarawak, and Trengganu. More equal distribution of educational opportunity is expected to result from the program.

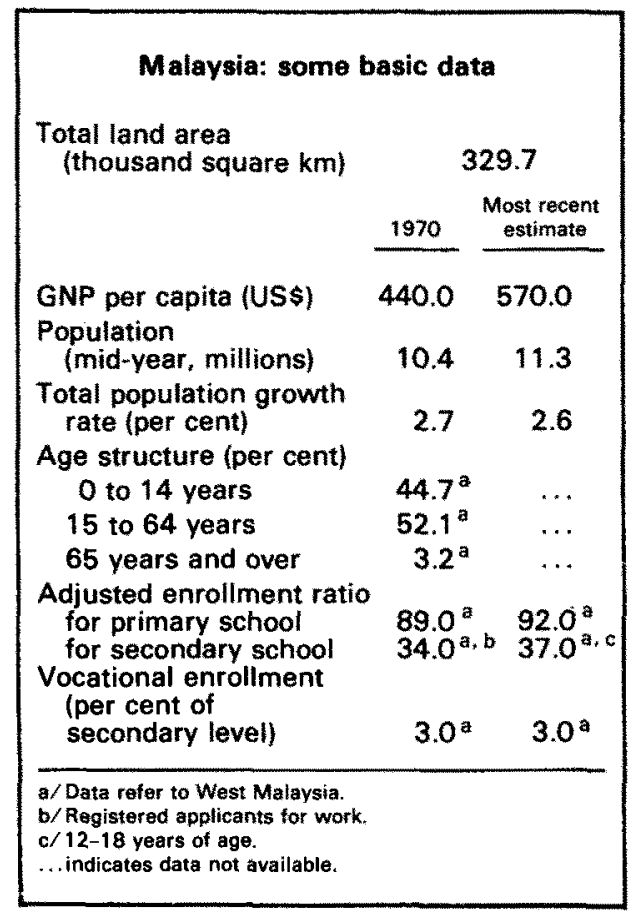

Primary education in these states has suffered largely because of poorly built, dimly lit, unhygienic buildings, crowded classrooms, and a lack of trained teachers. The project will benefit about 240,000 young people annually through the construction and equipment of 150 new primary schools and the expansion or replacement of about 700 primary schools. Primary school instruction will be improved through four education resource centers to be established for in-service training of teachers. At Miri, Sarawak, a teacher training college will be established also.

The capacity of vocational training institutions is insufficient to meet industry's demand for skilled manpower. Under the project, three new industrial training institutes will be established in

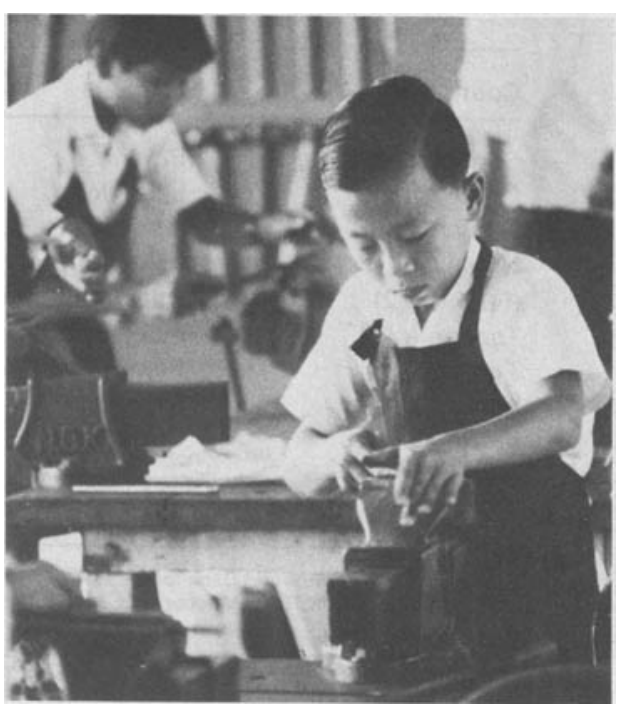

food processing technology, and timber industry mechanics. About 2,000 additional skilled workers a year will be trained to meet the country's expanding skilled manpower needs.

The project will provide technical assistance to the Malaysian Government to strengthen planning and implementation mechanisms for better allocation of resources for education among and within states; also for better school construction and selection of school sites. The project is to be completed in 1981 at a total cost of $\$ 124.6$ million.

The following eight financial institutions are participating in the Bank loan to the amount of approximately $\$ 3,650,000$ : Berliner Handels and Frankfurter Bank, Frankfurt, Germany: Inter-Alpha Asia (Hong Kong) Ltd., Singapore; Union Trust

Kuala Trengganu, Johore Bharu, and Kota Knabalu, and extensions will be made to the two existing institutes in Kuala Lumpur and Prai.

The industrial training institutions will offer, in addition to courses on mechanical, electrical, building, and printing trades, new courses such as tool and die-making,
Company, Stamford, Connecticut; The Tokai Bank, Ltd., Tokyo, Japan; National Bank of North America, New York; Manufacturers \& Traders Trust Co., Buffalo, New York; Industrial National Bank of Rhode Island, Providence, Rhode Island; and Marine Midland Bank, New York, New York.

World Bank loans approved during first quarter of fiscal 1977 (Ended September 30, 1976)

\begin{tabular}{llc}
\hline Country & Purpose & $\begin{array}{c}\text { Amount } \\
\text { (1n millions of U.S. dollars) }\end{array}$ \\
\hline Argentina & Power & 115.0 \\
Bahamas & Water supply & 10.0 \\
Bolivia (2) & Water supply, small mine credit & 23.5 \\
Brazil (2) & Water supply, agric. export industries & 123.0 \\
Cameroon & Ports & $15.0^{\mathrm{a}}$ \\
Dominican Republic (2) & Roads, population & $10.0 \mathrm{~b}$ \\
Guatemala & Reconstruction & $26.5^{\mathrm{c}}$ \\
India & Telecommunications & 80.0 \\
Indonesia & Transmigration & 30.0 \\
Kenya & Rural roads, agric. development, tourism & $31.0^{\mathrm{d}}$ \\
Korea (2) & Area development, agricultural credit & 49.0 \\
Liberia & Development finance company & 7.0 \\
Malaysia & Education & 35.0 \\
Mexico & Heavy industry & 95.0 \\
Pakistan & Development finance company & 25.0 \\
Senegal & Development finance company & 4.2 \\
Syria & Livestock & $17.5^{\circ}$ \\
Tanzania (2) & Forestry, power & $37.0 \mathrm{f}$ \\
Thailand & Development finance company & 25.0 \\
Turkey & Tourism & 26.0 \\
Zambia & Program & 30.0 \\
& & 814.7 \\
Total & & \\
\hline
\end{tabular}

a) With a $\$ 10$ million $10 \mathrm{~A}$ credit

b/Third Window loans.

c/Includes a $\$ 20$ million Third Window loan.

d/ Includes two Third Window loans (\$27 million); and with two IDA credits (\$14 million)

e/Includes a $\$ 12.5$ million Third Window loan.

$f /$ Includes a $\$ 30$ million Third Window loan. 


\section{Two more gold auctions are held}

The third gold auction by the Fund, as the trustee of the Trust Fund, was held on September 15,1976 , and 780,000 ounces of fine gold-the total amount for which bids were invited-were awarded to successful bidders at bid prices ranging from $\$ 108.76$ to $\$ 114.00$ an ounce. The average price of successful bids was $\$ 109.40$ an ounce. This was one of a series of auctions implementing the decision of the Interim Committee that a total of 25 million ounces of gold from the Fund's holdings is to be sold over a four-year period. The first auction was held on June 2, 1976, and the second on July 14, 1976.

Bids were received for a total quantity of $3,662,400$ ounces in the third auction. Of this quantity, 878,800 ounces were bid at $\$ 108.76$ or higher. One bidder offered $\$ 108.76$ for 106,400 ounces but this bid was met only in part. The gold is to be delivered at the Federal Reserve Bank of New York, U.S.A.

After payment has been made by the Trust Fund for the gold at the equivalent of SDR 35 a fine ounce, the award of 780,000 ounces at the third auction will yield a net sum of approximately $\$ 54$ million for the benefit of developing countries. The total amount available from the first three gold auctions is about $\$ 184$ million.

The terms and conditions of the gold auction state that no bid may be submitted by the government or monetary authorities of a member of the Fund or by an agent acting on behalf of these authorities, at a price inconsistent with the Articles of Agreement of the Fund. The Bank for International Settlements may submit bids. Each bidder is regarded as bidding on its own behalf if it submits a bid in its own name and for its own account and acquires ownership of gold as a result of a bid.

In the first gold auction, the prices offered by successful bidders ranged from $\$ 126.00$ to $\$ 134.00$ an ounce and averaged $\$ 126.98$ an ounce. In the second auction, held on July 14, the Fund awarded 780,000 ounces of gold to successful bidders at a common price of $\$ 122.05$ an ounce; bids submitted by successful bidders had ranged from $\$ 122.05$ to $\$ 126.50$ an ounce.

The major portion of the profits from the auctions-after payment for the gold at the equivalent of SDR 35 an ounce-will be available to finance loans by the Trust Fund on concessionary terms to eligible developing countries.
The Trust Fund was established in May 1976 (see "The Trust Fund," by Ernest Sturc, page 30 in this issue) to provide special balance of payments assistance to developing members with the profits from the sale of the Fund's gold, and with any financing that may be available from voluntary contributions or from loans.

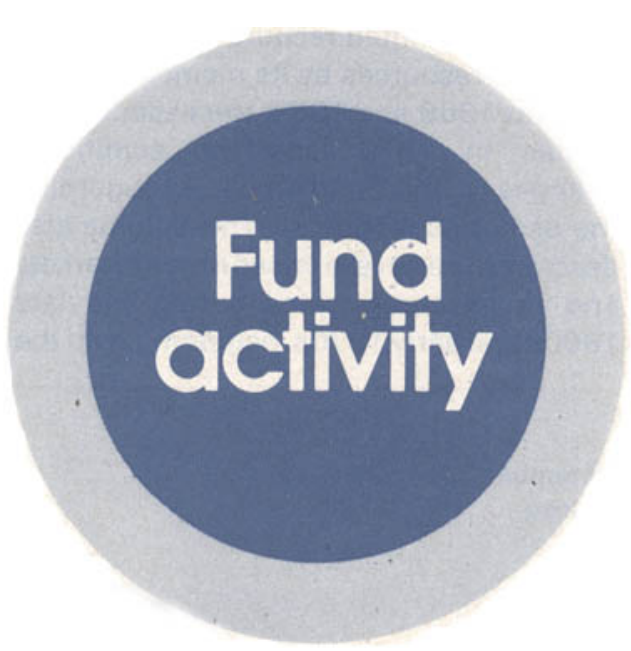

\section{...Four auctions net $\mathbf{\$ 2 4 5}$ million for Trust Fund}

The International Monetary Fund held its fourth gold auction as trustee for the Trust Fund on Wednesday, October 27. 1976. The Fund awarded 779,200 ounces of fine gold- 800 ounces less than the total amount for which bids were invitedto successful bidders at bid prices ranging from $\$ 116.80$ to $\$ 119.05$ an ounce, with an average price of $\$ 117.71$. The final 800 ounces could not be awarded because the amount was less than the minimum award of approximately 1,200 ounces provided for under the terms and conditions of the auction. Altogether, in the fourth auction, bids were received for a total of 4,214,400 ounces. As in previous auctions, the gold is to be delivered at the Federal Reserve Bank of New York.

Net of payment by the Trust Fund for the gold at the equivalent of SDR 35 per fine ounce, the award of 779,200 ounces will yield approximately $\$ 60.2$ million for the benefit of developing countries, bringing the total amount available from the four auctions held so far to about $\$ 245$ million.
Fund holdings of selected currencies as at September 30, 1976 (In millions of SDRs)

Austrian schillings

Belgian francs

Brazilian cruzeiros

Canadian dollars

Ecuadoran sucres

French francs

Deutsche mark

Guatemalan quetzales

Irish pounds

Japanese yen

Kuwaiti dinars

Luxembourg francs

Malta pounds

Netherlands guilders

Norwegian kroner

Qatar riyals

Swedish kronor

U.A.E. dirhams

U.S. dollars

Venezuelan bolívares
Per cent

Amount of quota

21.7

43.3

297.8

591.6

15.4

697.2

134.7

24.0

59.1

60.1

8.3

12.0

2.2

173.9

103.6

3.6

159.0

0.9

$3,284.3$

18.2
8

7

68

54

47

46

8

67

49

5

13

60

14

25

43

18

49

6

49

\section{Interim Committee emphasizes surveillance and management of monetary system}

The Interim Committee of the Board of Governors on the International Monetary System held its sixth meeting in Manila on October 2, during which it reached agreement on the need for the adjustment of member countries' external positions, the obligation of the Fund to exercise firm surveillance over the exchange rate policies of members, and the importance of keeping all aspects of international liquidity under review. The Committee also reviewed the financial activities and the liquidity of the Fund.

At a press conference following the meeting, the Committee's Chairman, Mr. Willy De Clercq, the Belgian Finance Minister, commented that in its previous meetings the Committee had focused especially, but not exclusively, on the task of drafting the Proposed Second Amendment to the Fund's Articles. He said the Committee can now address itself more to the task of the expert surveillance of the management and adaptation of the monetary system.

Mr. De Clercq said that the members of the ministerial level Interim Committee had agreed that economic recovery was under way, but expressed their concern about the high levels of unemployment and the high rates of inflation in many countries. 
This conclusion was underscored by the Committee in its communiqué. With respect to the international adjustment process, the Committee reported it had reached the following conclusions.

(a) In view of the recovery in the world economy, the Committee believed that the adjustment of external payments positions, which should be symmetrical between deficit and surplus countries, is now both urgent and opportune. (b) To this end, deficit countries should arrange their domestic policies so as to restrain domestic demand and permit the shift of resources to the external sector. (c) Industrial countries in strong payments positions should ensure continued adequate expansion in domestic demand, within the limits set by effective anti-inflationary policies. (d) Exchange rates should be allowed to play their proper role in the adjustment process. (e) In the context of the use of the Fund's resources, adjustment by deficit countries can be promoted by a larger use of the credit tranches and the extended Fund facility.

\section{Fund history 1966-71 due for release}

A two-volume history covering the work and evolution of the Fund during the six years 1966 through 1971 is due to appear early in 1977. The history, entitled The International Monetary Fund, 1966-1971: The System Under Stress, was written by Margaret Garritsen de Vries, the Fund's Historian.

The first volume traces in detail the negotiations leading to the creation of a new reserve asset, starting with the earliest discussions about international liquidity and culminating in the establishment of special drawing rights. It recounts the unprecedented recourse to the Fund's financial resources by its members, especially in 1968 and 1969; the expansion of quotas in 1970; and the significant changes in the Fund's policies regarding the use of its resources. This volume also describes the severe crises in gold markets and in exchange rates during the late 1960 s and early 1970 s, beginning with the

Selected data as at September 30, 1976

(In millions of SDRs)

Gold Account

Bars

$5,287.6$

SDRs in General Account

562.4

\begin{tabular}{lccc}
\hline Stand-by arrangements & $\begin{array}{c}\text { Amount } \\
\text { agreed }\end{array}$ & $\begin{array}{c}\text { Amount } \\
\text { purchased }\end{array}$ & $\begin{array}{c}\text { Undrawn } \\
\text { balance }\end{array}$ \\
\hline Argentina & 260.0 & 159.5 & 100.5 \\
Burundi & 6.5 & - & 6.5 \\
Costa Rica & 11.6 & - & 11.6 \\
Grenada & 0.225 & 0.225 & - \\
Guyana & 7.25 & 7.25 & - \\
Haiti & 6.88 & - & 6.88 \\
Liberia & 5.0 & - & 5.0 \\
Nepal & 4.495 & 4.495 & - \\
Panama & 9.0 & - & 9.0 \\
Romania & 95.0 & 95.0 & - \\
South Africa & 152.0 & 75.0 & 77.0 \\
United Kingdom & 700.0 & 700.0 & - \\
Uruguay & 25.0 & - & 25.0 \\
Western Samoa & 0.5 & 0.5 & - \\
Zaïre & 40.96 & - & 40.96 \\
Zambia & 62.0 & 8.5 & 53.5 \\
\hline \multicolumn{1}{c}{ Subtotal } & $1,386.41$ & 1.050 .47 & 335.94
\end{tabular}

Extended arrangements

\begin{tabular}{lrrrr} 
Kenya & 50.1 & 7.7 & 42.4 \\
$\begin{array}{l}\text { Philippines } \\
\text { Total }\end{array}$ & $90.0^{2}$ & 90.0 & - \\
\cline { 2 - 2 } & $1,526.51$ & & 1.148 .17 & 378.34
\end{tabular}

'Second phase through June 30, 1977 of a three-year arrangement totaling SDR 67.2 million

${ }^{2}$ First phase through December 31, 1976 of a three-year arrangement totaling SDR 217 million. devaluation of sterling in November 1967 and ending with the Smithsonian agreement of December 1971. A final section explains how the Fund has evolved as an international institution and describes some of its new activities.

The second volume makes available for the first time seven draft outlines for reserve-creating schemes prepared in the Fund. These are part of the process by which SDRs were established. This volume also reproduces the most important documents that the Fund published from 1966 until the end of 1971.

\begin{tabular}{|c|c|}
\hline \multicolumn{2}{|c|}{$\begin{array}{c}\text { Summary of transactions, } \\
\text { January 1-September } 30,1976 \\
\text { (In millions of SDRs) }\end{array}$} \\
\hline Total purchases & 6.179 .4 \\
\hline Gold tranche purchases & 875.5 \\
\hline Credit tranche purchases & $1,255.1$ \\
\hline Extended facility purchases & 90.0 \\
\hline $\begin{array}{l}\text { Compensatory financing } \\
\text { purchases }\end{array}$ & $1,815.5$ \\
\hline Oil facility purchases & $2,143.4$ \\
\hline Total repurchases & $1,109.1$ \\
\hline \multicolumn{2}{|l|}{ Net drawings } \\
\hline September 30,1974 & $4,402.7$ \\
\hline September 30,1975 & $8,513.3$ \\
\hline September 30, 1976 & $14,370.6$ \\
\hline
\end{tabular}

Note: Details may not add to totals due to rounding

This new history of the Fund is based on official records and documents, particularly minutes of the meetings of the Executive Board. However, material covering the Fund staff's analyses, the Managing Director's actions, and international economic and monetary events and discussions that influenced the Fund's actions in the years 1966-71 is also presented in these two volumes.

The publication of these two volumes is a sequel to the three-volume history of the Fund published in 1969, which covered the first twenty years of the Fund's existence-1945-65.

The author, Mrs. de Vries, was among the first members of the staff of the Fund, having joined the Research Department in 1946. She has held various positions on the staff, including Chief of the Far Eastern Division from 1957 to 1959 . From 1963 to 1973 she served as a Consultant to the Fund, and has been Historian since May 1973. She is a co-author of the earlier volumes of the Fund's history.

continued on page 44 


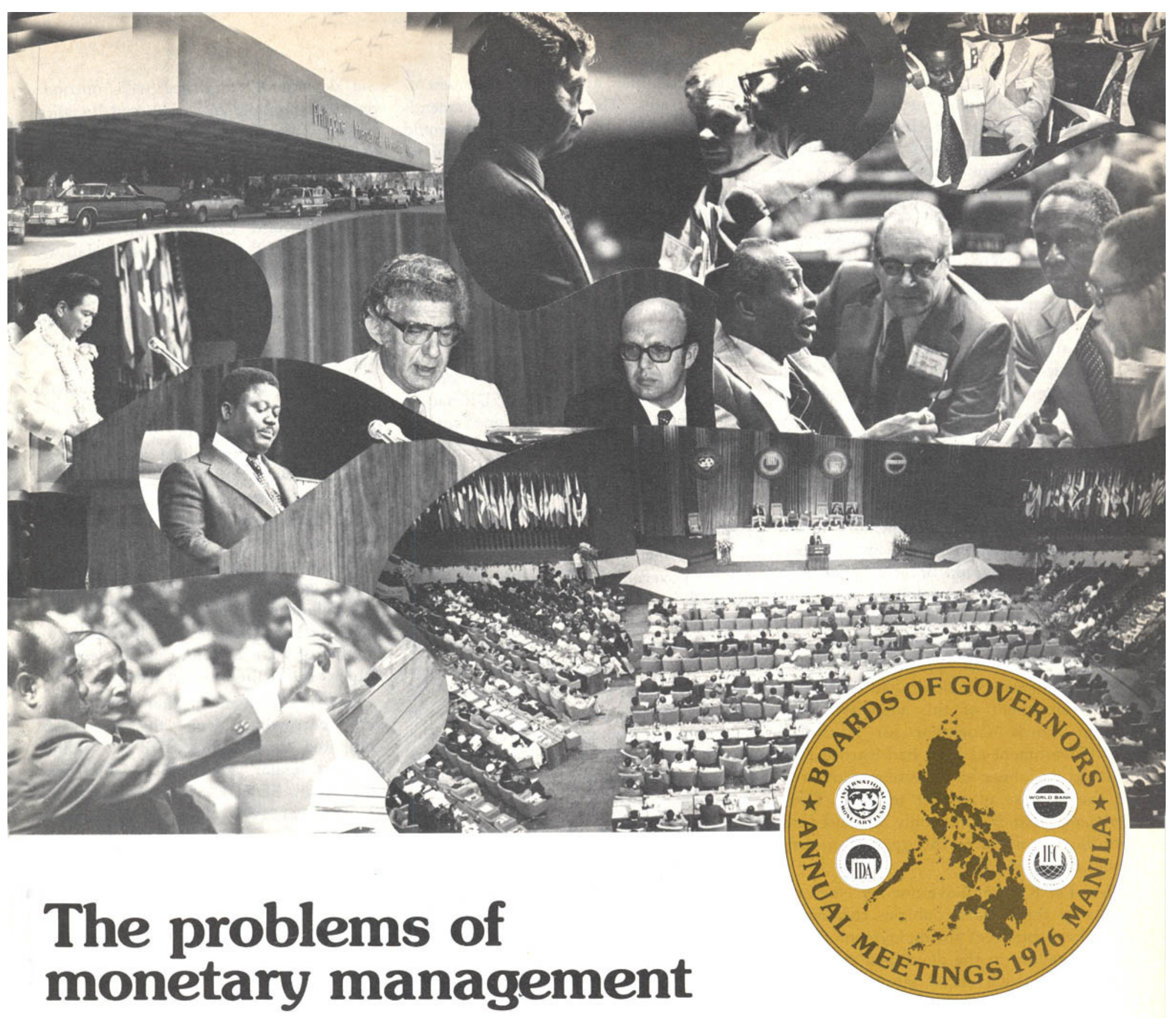

\section{This year's Annual Meeting of the Fund, while not dramatic in itself, discussed the intellectual background to a great deal of work still to be done. This article reports on the issues raised and the problems discussed.}

\section{John A. Kay}

As the Thirty-First Annual Meetings of the Boards of Governors of the Fund and the Bank were opened by Mr. Mohammed Imady, Governor for the Syrian Arab Republic, in the Philippine International Convention Center on October 4, 1976, hurricane weather was succeeded by clearing skies over Mar,ia Bay. This might serve as a metaphor for the economic climate described by many of the speakers, especially from the developed countries.
Mr. Johannes Witteveen, Managing Director of the Fund, suggested that as the weather changed, so Fund members should change their policies; now that economic recovery was under way, it was necessary to ensure that the resulting growth could be sustained. Mr. William Simon, Governor for the United States, supported the Managing Director's analysis. He outlined four tasks in improving the international economic system: to restore stability in members' economies; to make the reformed monetary system work; to tackle development with more courage and understanding; and to strive for an open and free order for world trade and investment.

Few speakers quarreled with Mr. Simon's approach, but there was some hesitation in translating it into action.

For instance, Mr. George Hosten, Governor for Grenada, brought "forcibly" to the attention of the Governors that almost all small developing island economies were still suffering from a weakening of demand in their principal markets, a sharp deterioration in their terms of trade, and a consequent rise in their combined deficits.

Mr. Witteveen had proposed that the developed countries should ensure that their attempted pace of development did 
not lead to a resurgence of inflation, and that they should open their markets more widely and add to development aid. On this point Mr. Felix Bandaranaike, Governor for Sri Lanka, remarked that the developing countries for more than a decade had called for dismantling the trade barriers that affected their exports. But barriers were now mainly quantitative and difficult to dismantle. If developed countries pursued demand management policies to control domestic inflation, while at the same time denying export access to developing countries, which were compelled to adjust by means of exchange rate changes, it was virtually certain that world economic activity would slow down, he said. Mr. Bandaranaike added that it was imperative that there should be a commitment from the developed countries to implement measures of import liberalization immediately. Only thereafter could orderly adjustment measures by the developing countries hope to succeed.

Yet there was little disagreement that attempts to fight unemployment by expansionary domestic policies had failed. A strong exponent of this view was $\mathrm{Mr}$. Phillip Lynch, Governor for Australia. His Government at least had learned that it could no longer buy less unemployment at the expense of higher inflation. Governments had become only too used to printing money over the years, but they could not print jobs.

Mr. Per Kleppe, Governor for Norway, said that the Nordic countries considered that the 5 per cent unemployment figure still prevailing in the developed countries implied so much social strain and economic waste that it should be a first priority of all members' endeavors to achieve a sustained recovery until unemployment had been reduced to more tolerable levels.

\section{The role of the SDR}

The Governors-and there were some 50 speakers in all-also devoted considerable time to the ways in which the Fund could help members. As Mr. Willy De Clercq, Governor for Belgium and Chairman of the Interim Committee put it, following the events of the past yearthe completion of negotiations on the Articles of Agreement, the decision on the quota increase, the establishment of the Trust Fund, the creation of the Subsidy Account, the liberalization of the compensatory financing facility, and the temporary expansion of access to the Fund's resources-the time had come for a new process of reflection in two areas: inter- national liquidity and the management of floating rates. The forthcoming amendment to the Fund's Articles, which would make the special drawing right (SDR) more flexible, was a step in the right direction-the SDR was originally created to ensure a responsible growth in liquidity; but the effective yield of the SDR was still lower than that of dollars invested in the money market. An increase in the vield was therefore essential if it was to become a true reserve asset.

Mr. Bernal Jiménez M., Governor for Costa Rica, remarked that the SDR had in fact been losing ground and now constituted only 4 per cent of total international reserves. Consequently, a portion of any new international liquidity that was created should take the form of SDRs. The second amendment of the Articles would make it easier to use SDRs, but since the policies governing their allocation had not changed, new SDRs could only be allocated if it was agreed that there was a medium-term shortage of global liquidity. That was a short-sighted view, he considered, because it ignored the need of the developing countries for reserves. Moreover, the two main restrictions on the use of SDRs remained. Consequently, the changes made were less important than those not made.

A request for a second allocation of SDRs, small in proportion to total world liquidity but large in relation to the present issue, was a theme taken up by many speakers whose constituencies included countries in the Group of 24. (The Intergovernmental Group of 24 on International Monetary Affairs is an emanation of the Group of 77 set up under the Declaration of Lima, 1971.) Not only would such an allocation endow the SDR with some credibility, it would provide

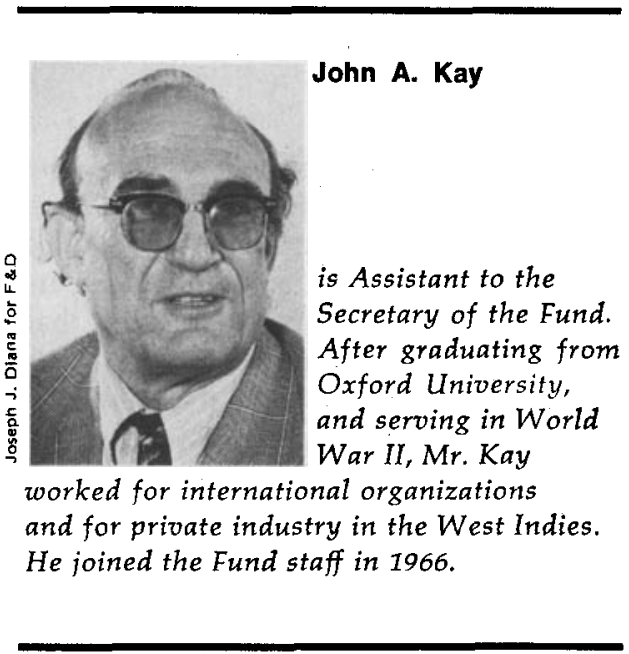

the developing countries with unconditional as opposed to conditional liquidity, while giving the Fund more control over the system as a whole.

\section{International borrowing}

Mr. Bernard Clappier, Governor for France, remarked that it was relatively easy to obtain international bank loans, and that any growth in that type of lending could well lead to a relaxation of the monetary and budgetary discipline that was now needed more than ever.

Madame Marie-Christiane Gbokou, Governor for the Central African Republic, responded that while some countries had been able to adjust their current payments by reducing their already small foreign exchange resources most of them had had recourse to external borrowing, often available only on onerous terms in private financial markets. Africa's external public debt, she said, had risen from $\$ 9.2$ billion in 1967 to $\$ 28.5$ billion in 1974, and the debt service burden for a number of African countries now equaled 20 per cent of their export receipts.

As more than one speaker noted, members' borrowings from the Fund had amounted to a record SDR 4.7 billion during calendar year 1975 and had been more than SDR 4.9 billion during the first half of 1976 alone. This increased rate of lending had caused the Executive Directors to look into the question of the adequacy of the Fund's liquidity for the future. Although some speakers felt that the Fund's liquidity was adequate for the immediate future, Mr. Jiménez, for instance, remarked that the Fund's liquidity position could prevent it from meeting fully the foreseeable financial needs of the member countries, especially as an industrialized country had recently applied for a large drawing. (The Alternate Governor for the United Kingdom confirmed during the meeting that his country would draw the resources available to it under the Fund's credit tranche policies.) In the circumstances, speakers agreed that there might be no alternative to activating the General Arrangements to Borrow. (See David Williams, "Increasing the resources of the Fund: borrowing," Finance $\mathcal{E}$ Development, September 1976.)

Mr. Donald S. Macdonald, Governor for Canada, felt that more countries should as a matter of urgency make their currencies freely usable for Fund transactions. (When the amended Articles come into effect, all members' currencies will be usable in accordance with the policies of the Fund.) 
There was fairly general support for the statement in the communique of the Interim Committee issued on Saturday, October 2, 1976, that with the improvement in world conditions, drawings from the Fund would as a general rule take place in the Fund's regular credit tranches and through the extended Fund facility. (This latter provides financing for longer than the Fund's usual three- to five-year period and is intended for member countries making structural changes in their economies.) Madame Gbokou, and others, asked that the facility be reviewed in order to bring about an easing of the conditionality attached to it.

Mr. N'Faly Sangaré, Governor for Guinea, considered that even the other new facilities - the compensatory financing and the buffer stock facilities-had such stringent conditions attached to them that most of the countries for which they were originally intended were obliged to do withcut them.

On the other hand, Mr. Karl Otto Poehl, Governor for the Federal Republic of Germany, remarked that the regular facilities of the Fund had been used amazingly little. Only six members had drawn in the second credit tranche, where conditionality really begins. In his view conditionality was a helpful guide to better economic performance, a useful instrument for improving the investment process, and a support to the credit standing of a country.

\section{Surveillance}

One of the subjects to which many Governors were clearly devoting considerable thought was how the Fund would carry out its enlarged powers of surveillance of members' exchange rate practices once the new Article IV came into force. One of the major changes to be brought about by the new Article would be that the cases of individual countries would be discussed at the political level, namely, in the Interim Committee. As Mr. Macdonald put it, "there may well be need to discuss specific situations from time to time, and this is why Canada supports strongly the surveillance responsibilities vested in the Interim Committee of the Fund." Mr. Mohamed Zaki Shafei, Governor for Egypt, considered the new Article IV to be of profound importance because it would give members the freedom to choose their own regimes. Nevertheless, the ultimate goal-also provided for under the new Article IV-ought to be progress toward a more stable monetary system, which might be one based on a system of stable but adjustable par values. Mr. Clappier insisted that the Fund could only fullfill its obligations if it exercised "firm" surveillance equally over surplus countries and deficit countries alike. He reminded Governors that, behind the exchange rate undertakings, every member had accepted a commitment to direct its economic and financial policies toward fostering orderly economic growth with reasonable price stability.

Mr. C. Subramaniam, Governor for India, remarked, however, that it would be extremely difficult to work out a truly

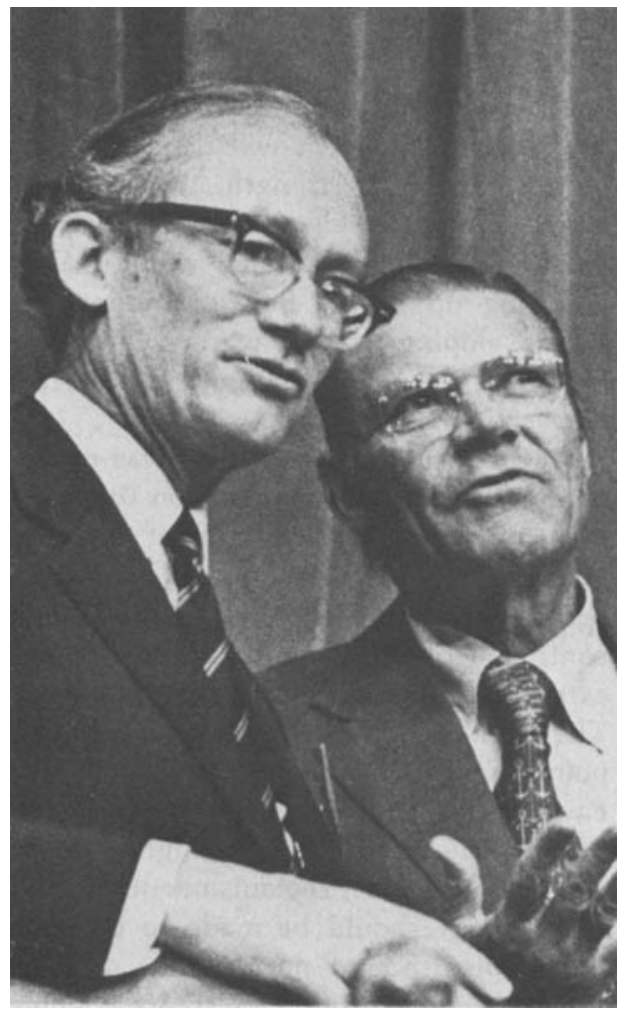

Mr. Witteveen and Mr. McNamara

objective system. There was a risk, he thought, that the developing countries would be placed under great pressure to adjust their exchange rates to correct balance of payments disequilibria, even at the cost of their impoverishment. Finally, Mr. Gaetano Stammati, Governor for Italy, believed that the Fund should use its powers of surveillance to ensure that the adjustment process operated in a symmetrical fashion without undue pressure on those that needed recourse to Fund resources.

\section{Exchange rates}

On the role of exchange rates themselves, Madame Gbokou considered that the risks inherent in a system of floating exchange rates were very costly to the concept of an orderly international monetary system. She considered the developed countries were better prepared to absorb the risks of erratic exchange fluctuations than were the developing countries with their limited room for maneuver. Mr. Simon, in contrast, devoted a passage to asking his listeners to imagine the disasters that would have befallen the world in recent years under a par value system. Mr. Poehl felt that floating rates were not the cause but the result of instability, and he subscribed to the communique of the Interim Committee that said that "exchange rates should be allowed to play their proper role in the adjustment process." Mr. Xenophon Zolotas, Governor for Greece, considered that as long as high rates of inflation persisted, no international monetary superstructure would be viable, and that the present nonsystem was likely to continue indefinitely. And Mr. Bandaranaike explained that in the case of developing countries, whose economies were relatively more rigid than those of the industrialized world, exchange rate changes took considerably longer to promote investment in new production capacity of the right kind-a case of the lag which Mr. Simon had described as a politician's nightmare.

The Fund being above all a financial agency, questions of aid as such were little discussed. One interesting view on aid was, however, put forward by $\mathrm{Mr}$. Julius Chan, Governor for Papua New Guinea; he said that he was concerned about any developments that might create an incentive for the accumulation of excessive domestic or foreign debt as a way out of short-term difficulties. If aid was provided more readily to countries with external debt or balance of payments problems, it was possible that the efforts of other poor countries to implement sensible policies would be undermined.

In his concluding remarks at the Annual Meeting, Mr. Witteveen stressed the primary significance of the general consensus reached on the need for greater emphasis on the adjustment of imbalances, as distinct from financing alone. Despite the concern of the primary producing countries that import expansion of the industrial countries would proceed more slowly if cautious policies prevailed, he sensed that they had concurred that it would be in their own interest if the industrial countries were "to conquer inflation." As a result of the discussions during the week in Manila, the Fund would need to intensify its work on problems of international liquidity, and high priority would be given to the Seventh General Review of Quotas, in which many Governors had suggested that there should be substantial increases. 


\section{Challenging human poverty}

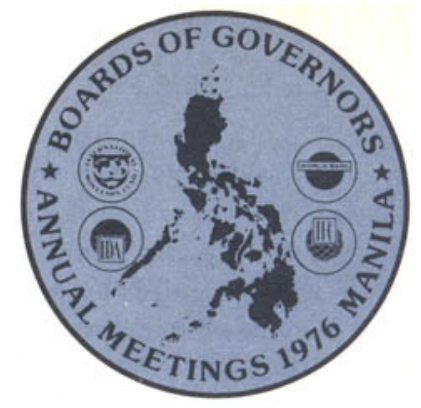

\section{A report on the Annual Meeting of the World Bank, held in Manila, the Philippines, October 4-8, 1976.}

\section{H-Joost Polak}

The tension of an international community caught between recession and inflation dominated the Thirty-First Annual Meeting of the World Bank Board of Governors.

Resources-the money needed to accelerate, or even continue, developmentwere the focal point of the Governors' speeches from the mahogany podium in front of the gleaming Romblon marble dais of Manila's brand-new Philippine International Convention Center.

"All other questions regarding the Bank's future-though many are important in themselves-are ancillary to this one basic issue: will the Bank, the International Development Association, and the International Finance Corporation be given the means needed to achieve the ends we all desire," said Dr. Mohammed Imady, Fund Governor for the Syrian Arab Republic, in his opening address as Chairman of the joint Bank and Fund meetings.

Developing country Governors, joined by some from the industrial world, issued a strong call for an expansion of Bank, IDA, and IFC operations to maintain their momentum as what Chairman Imady termed "the catalyst of development."

They spoke with urgency of the need to. refill Bank and IDA coffers to break the constraints threatening the continued growth of the sister institutions' contributions to development. A General Increase in the Bank's capital, a Fifth IDA Replenishment greater in real terms than its predecessor, and an easing of the Bank's recently hardened loan terms and operational ceiling led their agenda for the Group's future.

On this last question, other nations cautioned prudence, pointing to the specter of inflation and urging more cautious operational growth to guard the Bank's long-term financial soundness.
"We must not sacrifice the prospects of future growth, which will depend on the Bank's financial strength, by mistaken policies in the field of interest rates and lending terms, policies that would lead to a drying up of the flow of money into the developing world," warned Sir Douglas Wass, the United Kingdom's Alternate Governor.

At the meeting's close there was neither unanimity nor confrontation on the major items on the agenda. What evolved, according to Mr. McNamara, was "clear agreement that the World Bank should continue to be a major source of the external financial assistance required." The Bank President detailed the four points on which a general consensus had emerged: (1) that there must be a substantial replenishment of IDA, higher in real terms than the last replenishment; (2) that every effort should be made to complete IDA replenishment negotiations so as to avoid any interruption in IDA's commitment authority; (3) that World Bank lending, in real terms, should neither decline nor remain static in the future; and (4) that member governments should proceed expeditiously to ratify the proposed $\$ 480$ million increase in IFC's capital.

The Governors were of one mind that IDA Replenishment was, as Sir Douglas said, "critically urgent." The industrial countries, generally, responded positively to the developing countries' concern that every effort should be made to reach agreement as quickly as possible on a substantial increase in IDA resources. There was also a consensus that some mechanism should be found to provide IDA with commitment authority after June 30, 1977, when the resources available from the Fourth Replenishment would have been fully committed.

Developing country Governors termed a continued and growing flow of IDA assistance, in the words of Mr. M. N.
Huda, Governor for Bangladesh, "a life and death issue." Failure to complete negotiations quickly and mobilize advance contributions to the proposed Fifth $\mathrm{Re}$ plenishment would break "a vital lifeline" for more than a billion poverty-stricken people, Mr. Huda said.

Several Governors hoped that more of the OPEC countries, whose magnanimity in development assistance was "salutary," would play their full part in the replenishment exercise.

\section{A global compact}

The major themes-resources, the terms under which the Bank could make them available for development, and, indeed, the resulting character of the World Bank itself-were sounded early in the meeting.

Behind the reasoned and often technical agenda of trade, aid, debt relief, commodity stabilization, and financial policies the Governors had set themselves stood "the implacable face of human poverty," Philippine President Ferdinand E. Marcos reminded the Governors in his welcoming address.

"This is the real beast we have to subdue," President Marcos told the packed opening session of the Annual Meeting. "Sentiment alone, though it may travel at unusually high velocities, will not suffice," he added. "Proposals must now pass into programs that work. We must step into authentic expansion and growth."

In his strong and emotional opening statement, Mr. McNamara called for a "global compact" through which the existing dialogue between rich and poor nations could be extended to reach agreement on the nature and the magnitude of the resource transfer problem and what steps-domestic and internal-should be taken to confront the "inhuman degradation" hundreds of millions of the absolute poor "are condemned to."

"What is fundamental," he said, "is that the developing nations must make a strong commitment to internal policy reforms; and the developed nations must, in their turn, make a comparable commitment to provide a more adequate amount of development assistance. ..." 
The specific forms of such assistance, he added, were less important than the agreement on "a basic understanding" on the fundamental issues of "the overall magnitude of the trade assistance and capital requirements within a given time frame; and the scope of the internal policy reforms that will assure its cost effectiveness.

"Once these two fundamental issues have been agreed upon, the specific negotiations will have a pragmatic framework in which to proceed."

Recapitalization of the Bank and replenishment of IDA were needed to lift the constraints on the Bank Group's full participation in this effort.

"If steps are not taken-and taken promptly-to relieve the resource constraints facing the Bank," he said, "its record of growing assistance to the developing nations will come to an abrupt halt.

"I do not believe a reduction in the real value of IBRD lending in the next two or three years is an objective desired by any of the Bank's member countries," Mr. McNamara said. "If we allow it to happen, it will be by default, not by design."

The Bank President sketched three "viable" options for increasing the volume of Bank operations in the next two or three years: an "undesirable" further hardening of repayment terms; an increase in commitments above the level sustainable without a further capital increasewith the danger that operations would have to be reduced if no increase were forthcoming; or "to structure the discussions of the Bank's recapitalization in a way which would permit an agreement by next June" on a further capital increase allowing "reasonable growth for the Bank." He urged that a decision on these alternatives be made in the very near future.

\section{Fifth IDA Replenishment}

Mr. McNamara also reported to the Governors that progress on a Fifth IDA Replenishment had been "painfully slow," warning them that "failure to support
IDA will be interpreted-and not unreasonably-as a clear indication that the international community's concern for the poor is little more than empty rhetoric."

Noting that several governments had supported the concept of a $\$ 9$ billion replenishment, and that the Kuwaiti Government had expressed its willingness to quadruple its share in the Association if the traditional OECD donors maintained their historical shares-raised by inflation to an estimated $\$ 7.2$ billion to $\$ 7.5$ billion shares-he said he was "optimistic" that a total replenishment of between $\$ 8-9$ billion "can be successfully negotiated."

He saw, however, "almost no chance that negotiations will be completed in time to permit legislative ratification by June 1977, when IDA's present commitment authority ends."

"There is no practical action available to repair the reduction in IDA commitment authority this year," he said, "but we can and must act to prevent a complete hiatus in IDA operations" through a speedy agreement on "bridging arrangement's."

Developing country Governors, led by Chairman Imady, saw the effects of constraints on Bank and IDA operations as a threat to the Bank's very character.

\section{Harder lending terms}

Continuation of the formula of harder lending terms necessitated by these constraints "could transform the World Bank from the world's leading development

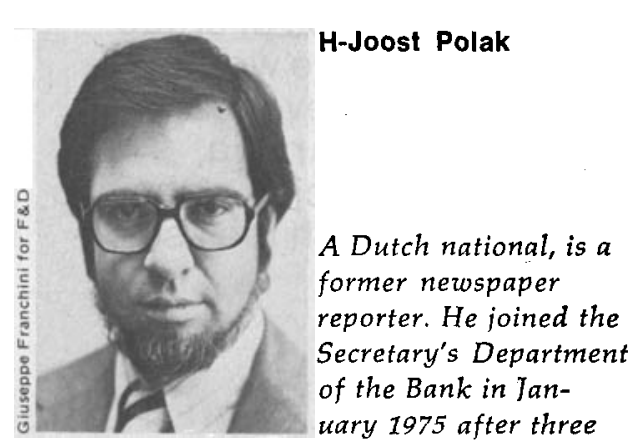

years at the Asian Development Bank. institution into a commercial institution," Chairman Imady stated in an opening address phrase echoed by Governors representing more than a dozen developing nations and the Nordic countries.

While welcoming the $\$ 8.3$ billion Selective Capital Increase proposed by the Executive Directors in March, and urging its approval by the Governors, Chairman Imady and other speakers said the concurrent agreement to freeze Bank operations at $\$ 5.8$ billion a year and harden loan terms had been a "high price." "This price will be paid by the developing countries, the very countries the Bank was created to assist," the Chairman said, urging that the restrictions "be abolished as soon as practicably possible."

The differing viewpoints of the developed and developing countries surfaced most strongly on this issue, with Malaysian Governor Tengku Razaleigh Hamzah terming the policies "insensitive," and the Governor representing the African nations, the Central African Republic's Marie-Christiane Gbokou complaining that the formula for determining Bank lending rates had been "arbitrarily imposed on us."

Several industrial country Governors, on the other hand, noted the Bank's new loan term policies and operational ceilings with approval. "The steps now being implemented . . . are basic to its continued ability to serve the developing countries through its essential role of borrowing funds and relending them on more favorable terms and in larger volume than those countries themselves can secure," said Australia's Treasurer, Phillip Lynch. He added that "prudent financial management," and "the quality of the Bank's work," were of greater importance than "rapid growth," which "is not the essence of the Bank's development role."

A similar viewpoint was expressed in the statement of Mr. Simon, who said he did not believe that the Executive Directors' agreement-in connection with the Selective Capital Increase-to limit Bank commitments to a level that would not continued on page 46
The World Bank Annual Meetings
The report in this issue of Finance \& Development on the Bank Annual Meetings is greatly condensed, touching only upon a small portion of the speeches and proceedings.

A more complete record, Summary Proceedings, is available now in English and will be available in February in French and Spanish free on request from

: Publications Office, The World Bank, 1818 H Street, N.W., Washington, D.C. 20433, U.S.A.

The World Bank, 66, avenue d'léna, 75116 Paris, France 

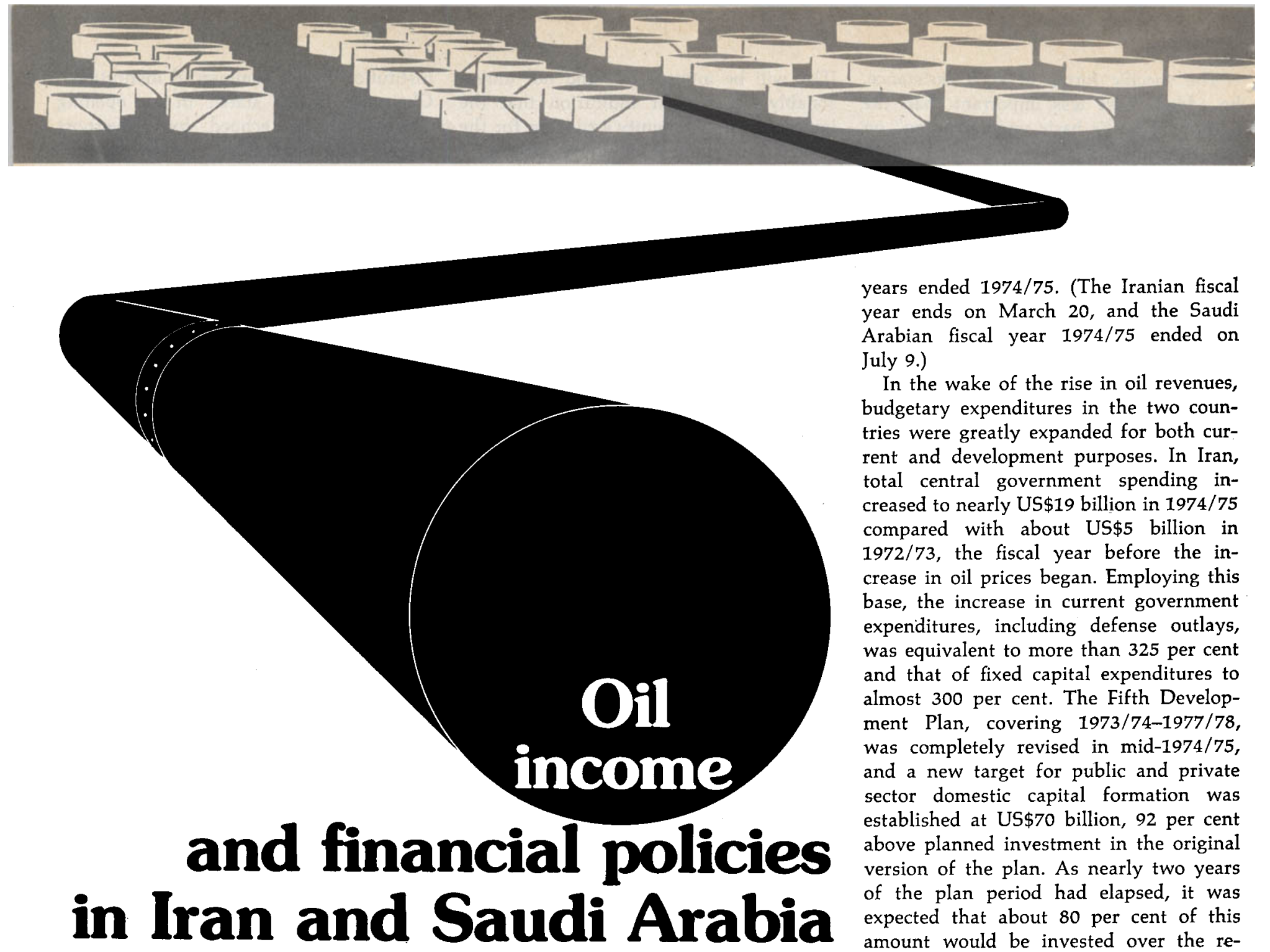

\begin{abstract}
With oil revenues greatly enhanced by the sharp rise of crude petroleum prices, the two largest oil exporters in the world have been faced with the task of absorbing these revenues.

The authors, Fund experts on Iran and Saudi Arabia, respectively, examine the fiscal and monetary policies of the two countries, and outline the problems associated with the use of increased oil revenues.
\end{abstract}

\section{Henry E. Jakubiak and M. Taher Dajani}

For most developing countries, a major consideration in economic planning has been the existence of revenue and foreign exchange constraints, limiting the ability to fund new investment and social projects and to purchase imported goods required for project implementation. Saudi Arabia and Iran, on the other hand, as the two largest oil exporters in the world, have had their fiscal and foreign exchange positions substantially enhanced by the recent sharp increases in crude petroleum prices.

Between October 1973 and January years ended 1974/75. (The Iranian fiscal year ends on March 20, and the Saudi Arabian fiscal year $1974 / 75$ ended on July 9.)

In the wake of the rise in oil revenues, budgetary expenditures in the two countries were greatly expanded for both current and development purposes. In Iran, total central government spending increased to nearly US $\$ 19$ billion in 1974/75 compared with about US $\$ 5$ billion in $1972 / 73$, the fiscal year before the increase in oil prices began. Employing this base, the increase in current government expenditures, including defense outlays, was equivalent to more than 325 per cent and that of fixed capital expenditures to almost 300 per cent. The Fifth Development Plan, covering 1973/74-1977/78, was completely revised in mid-1974/75, and a new target for public and private sector domestic capital formation was established at US\$70 billion, 92 per cent above planned investment in the original version of the plan. As nearly two years of the plan period had elapsed, it was expected that about 80 per cent of this amount would be invested over the remaining three years with the bulk of investment outlays originating from the public sector. Priority in the allocation of investment funds was accorded to petroleum and petrochemicals, basic industries, such as steel and copper, and manufacturing lines employing these inputs. In addition, considerable investment in ports and inland transportation infrastructure was foreseen in order to overcome already evident supply constraints. Among current expenditures, allocations for manpower training were also expanded.

In the case of Saudi Arabia, budgetary outlays were also sharply increased, rising by 260 per cent to US $\$ 9$ billion in the two-year period ended 1974/75. While current expenditures, including foreign aid, rose by nearly 200 per cent, project expenditures expanded fourfold, to almost US $\$ 5$ billion, with much of the expansion recorded in outlays for communications, education and health, municipalities, and defense. As a result of this acceleration in government spending, the target expenditure level under the First Five-Year Development Plan (1970/71-1974/75) was ex- 
ceeded by 67 per cent. In May 1975, Saudi Arabia launched its Second FiveYear Development Plan, covering the period through $1979 / 80$. The plan called for total government expenditures of US\$141 billion, more than seven times the amount spent under the first plan. About two thirds of plan allocations was to cover the cost of projects for the development of infrastructure, agriculture, industry, and education; the industrial program focused on hydrocarbon-based industries, including major plants for gas gathering and treatment, and production of petrochemicals.

The increase in public spending following the surge in oil revenues made a substantial contribution to economic growth in both countries and provided a strong stimulus to economic activity in the private sector. In 1974/75, the real growth rate of Iran's non-oil gross domestic product (GDP) accelerated to 17 per cent and that of Saudi Arabia to 14 per cent. Although the gains in output were considerable, the domestic productive capacities of both economies were strained by the expansion in aggregate demand, and the acceleration in real growth was accompanied by inflationary pressures.

\section{Money, constraints, and prices}

In 1974/75 the supply of money and quasi-money increased by 57 per cent in Iran and by 61 per cent in Saudi Arabia compared with an annual average increase of 32 per cent and 40 per cent, respectively, over the preceding two years. The factors affecting the growth in domestic liquidity may be seen from two points of view. Employing the consolidated accounts of the banking system, the accumulation of net foreign assets by the banks appears as the primary expansionary determinant, offset by any buildup in net public sector deposits resulting from budgetary surpluses. However, since the main factor underlying the rise in net foreign assetsthe receipt of oil revenues by the government-has no immediate monetary effect (being directly counterbalanced by an equivalent rise in government deposits), an alternate and analytically more meaningful approach to monetary analysis for the two oil exporting economies is to redefine the determinants of growth in domestic liquidity by employing the balance of payments and public sector budget identities. The advantage of this procedure is to isolate the effect of budget operations on changes in domestic liquidity, by defining the growth of money and quasimoney essentially as a function of public sector net domestic expenditures (public from the monetary and balance of payments accounts, and are derived primarily as the difference between net external receipts of the public sector and the increase in net public sector deposits with the banking system. For this reason, the estimates of net domestic expenditures presented below are not strictly comparable with data in the central governments' budgetary accounts.)

\begin{tabular}{|c|c|c|c|c|}
\hline \multicolumn{5}{|c|}{$\begin{array}{l}\text { Table } 1 \\
\text { Iran: summary of foreign exchange receipts and payments } \\
\text { (ln billions of U.S. dollars) }\end{array}$} \\
\hline Year ended March 20 & $1972 / 73$ & $1973 / 74$ & $1974 / 75$ & $1975 / 76$ \\
\hline A. Receipts from the oil sector & 2.60 & 4.83 & 18.67 & 19.05 \\
\hline B. Other goods and services (net) & -2.70 & -4.71 & -10.06 & -16.26 \\
\hline Exports, f.o.b. & 0.47 & 0.64 & 0.69 & 0.65 \\
\hline Imports, c.i.f. & -2.99 & -4.96 & -10.64 & -16.04 \\
\hline Private sector & $(-1.57)$ & $(-2.70)$ & $(-5.02)$ & $(-7.62)$ \\
\hline Public sector & $(-1.42)$ & $(-2.26)$ & $(-5.62)$ & $(-8.42)$ \\
\hline Services (net) & -0.18 & -0.39 & -0.11 & -0.87 \\
\hline C. Total $(A+B)$ & -0.10 & 0.12 & 8.61 & 2.79 \\
\hline D. Nonmonetary capital & 0.59 & 0.93 & -1.98 & -3.13 \\
\hline Official loans and credits (net) & 0.52 & 0.76 & -2.20 & -2.88 \\
\hline Private captial (net) ${ }^{1,2}$ & 0.07 & 0.17 & 0.22 & -0.25 \\
\hline E. Errors and omissions (net) & --- & 0.10 & -0.47 & -0.24 \\
\hline $\begin{array}{l}\text { F. Total }(C+D+E) \\
\text { G. Monetary movements }{ }^{2,3}\end{array}$ & 0.49 & 1.15 & 6.16 & -0.58 \\
\hline (increase in assets -) & -0.49 & -1.15 & $-6.16^{4}$ & 0.584 \\
\hline $\begin{array}{l}\text { Source: Bank Markazi Iran. } \\
\text { I Iranian rials were converted into U. } \\
1972 / 73, \text { RIs } 75.786 \text { US } \$ 1 ; 1973 / 74, \\
\text { RIs } 68.214=\text { US } \$ 1 ; 1976 / 77 \text {, RIs } 70.50 \\
2 \text { Includes unclassified capital payments } \\
\text { 3 These data differ from yearly chang } \\
\text { partly to differences in the treatment of c } \\
\text { + Includes lending to the Fund's oil fa } \\
\text {-- indicates data not significant. }\end{array}$ & $\begin{array}{l}\text { Iollars at th } \\
68.00=U \\
\$ 1 \text { (estimate } \\
\text { in net forei } \\
\text { in accountin } \\
y \text { and purch }\end{array}$ & $\begin{array}{l}\text { ollowing a } \\
; 1974 / 75 \text {, } \\
\text { assets as } \\
\text { entries. } \\
e \text { of World }\end{array}$ & $\begin{array}{l}67.547= \\
\text { wrin in mone } \\
k \text { bonds. }\end{array}$ & $\begin{array}{l}\text { hange rates: } \\
\$ 1 ; 1975 / 76 . \\
\text { ry data due }\end{array}$ \\
\hline
\end{tabular}

sector domestic spending less domestic revenues), the increase in private sector borrowing from the banking system, and the latter's balance of payments position. This alternate approach identifies the rapid growth in public sector, and primarily central government, net domestic expenditures in Iran and Saudi Arabia as the main factor accounting for the acceleration in the rate of monetary expansion (see Tables 2 and 4 ). In fact, in both countries the monetary impact of private sector economic activity was contractionary on a net basis as the private sector balance of payments deficit exceeded the growth of credit to that sector. (Because of statistical difficulties, public sector net domestic expenditures are estimated by employing data
The magnitude of public sector net domestic expenditures in 1974/75 in Iran and Saudi Arabia gave rise to levels of aggregate demand incommensurate with supply availabilities from domestic and external sources. Existing domestic production capacities were small relative to the growth in demand; and full capacity utilization in many areas of production was quickly approached. In addition, the expansion of domestic capacity in the short run was constrained by normal gestation lags and physical limitations-both countries, for example, were confronted with acute shortages of skilled manpower. Although interim measures were introduced to expand the supply of skilled labor, including the employment of for-

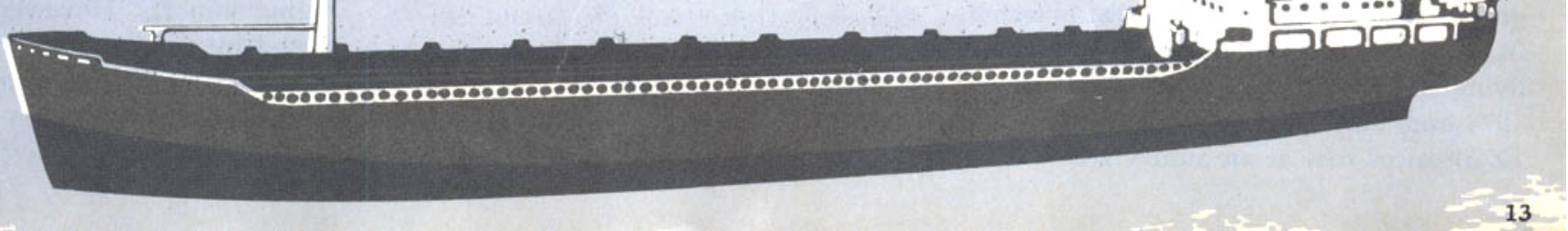


eign technicians and professionals and contracting out projects to foreign firms supplying their own labor, the demand for labor could only partly be met from these sources. The creation of the skilled cadres needed for the completion of the new expenditure plans called for extensive training programs for domestic labor or measures facilitating an expanded entry of foreign workers.

With regard to the external sector, public and private sector imports in both countries expanded rapidly in 1974/75 and alleviated the buildup in domestic demand pressures. Direct public sector foreign exchange outlays for imports, supplemented by official capital outflows, contributed to limiting public sector net domestic expenditures. In Iran, public sector payments abroad for imported goods and services rose from nearly US\$3 billion in $1973 / 74$ to about US $\$ 7$ billion in 1974/75, while government foreign aid, loans, investments, and accelerated debt repayments yielded a net official capital outflow of more than US $\$ 2$ billion. Similarly, in Saudi Arabia, public sector imports of goods and services approximately doubled to US $\$ 3$ billion in $1974 / 75$, and foreign aid rose steeply. However, despite the growth in import expenditures and budget surpluses, the magnitude of public sector net domestic spending was substantial in both countries, and the expansionary impact on domestic liquidity from this source was only partly offset by private sector external payments deficits adjusted for increased private sector borrowing.

Although the authorities in Iran and Saudi Arabia had attempted to realize higher levels of public and private sector imports, this was inhibited by bottlenecks in the ports. Despite an augmentation of effective port capacity, the number of ships waiting at the ports grew substantially, and the average period for offloading rose to between two to four months for goods not accorded special priority, resulting in mounting interest and demurrage costs. Similarly, the virtually fixed short-run supply of inland transportation and warehousing services also inhibited the absorption of imports into the economy. As a result of these factors, the leakage of demand pressures through the current account of the balance of payments was constrained below desired levels.

With physical limitations on supply, the growth of aggregate demand was reflected in rising price levels. In Iran the cost of living index increased by 14 per cent in 1974 and, during the first half of calendar 1975 , prices rose at an annualized rate of
29 per cent. In Saudi Arabia the increase in the Riyadh cost of living index accelerated from 17 per cent in 1973 to 35 per cent in 1975 . While some proportion of the rise in prices was attributable to higher costs of imported goods, most of the increase originated within the domestic economy. Measures were introduced by the authorities in both countries to reduce the impact of inflation on the domestic cost of living-including the reduction or abolition of import duties on a broad range of commodities and the introduction of subsidies for foodstuffs and other basic goods. In Iran quantitative restrictions on imports were also substantially eased.

\section{Adjustment of financial policies}

The sharp monetary expansion during $1974 / 75$ resulted in a considerable liquidity carry-over into the following year in both economies, and as physical constraints remained largely unrelieved, aggregate supply and demand imbalances and upward trends in prices persisted. Under these circumstances, the authorities began to reassess existing policies.

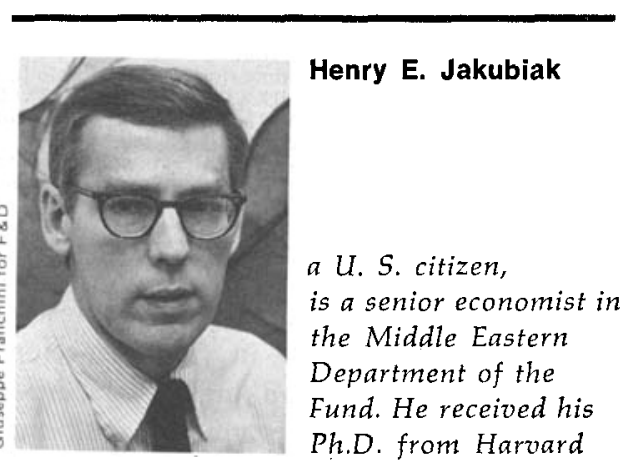

University and taught economics at Rutgers University before joining the Fund staff in 1974.

\section{Taher Dajani}

a Jordanian, joined the Fund staff in January 1965 as an economist in the Bureau of Statistics. He transferred to the Middle Eastern Department in July 1974 and became Assistant Division Chief in the Central Division in May 1976. He was recently appointed Fund Resident Advisor in Afghanistan. Mr. Dajani was educated at the University of Syria in Damascus and at De Paul University, Chicago.
In Iran, a surge in public sector expenditures during the last quarter of 1974/75, reflecting a drawdown of deposits with the banking system, resulted in a sharp buildup in domestic liquidity and the intensification of inflationary pressures. As an initial response, a severely administered price control program was introduced at midyear to stem the mounting inflationary thrust of the economy and alter inflationary expectations. With this program, the upward movement in prices was suppressed. However, the authorities were aware that these measures by themselves would not moderate the underlying excess demand pressures in the economy, and decisions were taken concomitantly to restrain the rate of increase in public sector expenditures. The decision to slow the growth in budget outlays was partly engendered by stagnating oil sector revenues; although oil prices increased by about US\$1 per barrel during 1975, world demand for oil continued to slacken, and Iranian petroleum exports fell by over 10 per cent for the year as a whole. Central government budget outlays for 1975/76 were held close to original estimates and rose by about 20 per cent, considerably below the extraordinary rate of increase in the previous year. The absolute increase still amounted to over US\$4 billion; however, a sharper deceleration in expenditure growth was considered undesirable due to the possible adverse consequences for economic growth.

With altered fiscal policies, Iran's public sector net domestic expenditures in 1975/76 are estimated to have been held at approximately the level prevailing in the previous year, declining, however, as a proportion of the domestic money stock. The containment of net domestic expenditures largely reflected a shift in the distribution of government outlays away from domestic and toward external supply sources, as public sector imports increased by 50 per cent. The estimated private sector balance of payments deficit widened considerably, and although the rate of growth of private sector borrowing increased, on a net basis private sector economic activity exercised a stronger contractionary influence on the growth of domestic liquidity than in the previous year. Reflecting the policy of demand restraint, the rate of monetary expansion was reduced to 41 per cent. On the supply side, some progress was made in facilitating imports. However, limitations imposed by full capacity utilization as well as other physical bottlenecks began to constrain increases in non-oil GDP and were particularly reflected in a diminish- 
Table 2

Iran: factors affecting changes in money and quasi-money (In billions of U.S. dollars)

\begin{tabular}{|c|c|c|c|c|}
\hline Year ended March 20 & $1972 / 73$ & $1973 / 74$ & $1974 / 75$ & $1975 / 76$ \\
\hline A. Changes in money and quasi-money & 1.36 & 1.71 & 4.36 & 4.92 \\
\hline B. Public sector net domestic ex- & 161 & 274 & 870 & 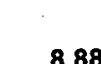 \\
\hline $\begin{array}{l}\text { C. Monetary impact of private sector } \\
\text { Changes in claims on private sec- }\end{array}$ & 0.17 & 0.01 & -1.13 & -2.03 \\
\hline $\begin{array}{l}\text { tor (increase }+ \text { ) } \\
\text { Private sector lending to Central }\end{array}$ & 1.12 & 1.86 & 3.10 & 5.53 \\
\hline $\begin{array}{l}\text { Government (increases }-)^{3} \\
\text { Private sector balance of pay- }\end{array}$ & -0.07 & -0.11 & -0.02 & $\ldots$ \\
\hline $\begin{array}{l}\text { ments (deficit -) } \\
\text { D. Changes in net unclassified bank }\end{array}$ & -0.88 & -1.74 & -4.21 & -7.56 \\
\hline liabilities ${ }^{4}$ & -0.27 & -0.67 & -1.64 & -1.38 \\
\hline E. Discrepancy ${ }^{5}$ & -0.15 & -0.37 & -1.57 & -0.55 \\
\hline
\end{tabular}

Sources: Fund staft calculations, based on data provided by Bank Markazj Iran.

See footnote 1, Table 1 .

2 Derived as the sum of public sector net foreign exchange receipts, as recorded in the foreign exchange receipts and payments statement, and the increases in net bank cląims on the public sector (including import deposits) and nonbank holdings of government bonds.

3 inciudes central government bonds held by public sector agencies.

Excludes public sector import deposits.

Discrepancy between changes in money and quasi-money as presented in the aggregated balance sheets of the banking system and as derived from lines $B, C$, and $D$. The discrepancy arises mainly from differences in accounting definitions and classifications in the monetary and foreign exchange receipts and payments accounts.

.. indicates data not available.

Table 3

Saudi Arabia: summary balance of payments estimates (In billions of U.S. dollars) ${ }^{1}$

\begin{tabular}{|c|c|c|c|c|}
\hline Fiscal years & $1972 / 73$ & $1973 / 74$ & $1974 / 75$ & $1975 / 76$ \\
\hline $\begin{array}{l}\text { A. Receipts from the oil sector (net) } \\
\text { B. Other goods, services, and private }\end{array}$ & 3.63 & 11.49 & 27.80 & 28.18 \\
\hline transfers & -2.09 & -3.92 & -5.50 & -9.22 \\
\hline Exports, f.o.b. & 0.02 & 0.03 & 0.04 & 0.06 \\
\hline Imports, f.o.b. & -1.58 & -2.75 & -4.86 & -8.04 \\
\hline Private sector & $(-1.22)$ & $(-2.09)$ & $(-3.43)$ & $(-5.27)$ \\
\hline Government sector & $(-0.36)$ & $(-0.66)$ & $(-1.43)$ & $(-2.77)$ \\
\hline Services and private transfers (net) & -0.53 & -0.57 & -0.68 & -1.24 \\
\hline $\begin{array}{l}\text { C. Total }(A+B) \\
\text { D. Official transfers and miscella- }\end{array}$ & 1.54 & 8.20 & 22.30 & 18.96 \\
\hline neous capital & 0.03 & -1.49 & -2.31 & -4.12 \\
\hline Official transfer payments & -0.35 & -0.77 & -1.29 & -1.99 \\
\hline Private capital (net) ${ }^{2}$ & 0.38 & -0.72 & -1.02 & -2.13 \\
\hline E. Total $(C+D)$ & 1.57 & 6.71 & 19.99 & 14.84 \\
\hline $\begin{array}{l}\text { F. Change in net foreign assets of } \\
\text { SAMA }{ }^{3} \text { and commercial banks } \\
\text { (increase in assets -) }\end{array}$ & -1.57 & -6.71 & -19.99 & -14.84 \\
\hline
\end{tabular}

Source: Estimates based on balance of payments data for calendar years 1972-75 (provided by the Saudi Arabian authorities), and projections for 1976.

1 Saudi Arabian riyals were converted into U.S. dollars employing the following annual average exchange rates: $1972 / 73$, SRIs $3.935=$ US $\$ 1 ; 1973 / 74$, SRIs $3.556=$ US\$1; 1974/75, SRIs 3.529 $=$ US $\$ 1 ; 1975 / 76$, SRIs $3.528=$ US $\$ 1 ; 1976 / 77$, SRIs $3.530=$ US $\$ 1$, estimated)

2 Includes net errors and omissions.

Saudi Arabian Monetary Agency.

ing rate of expansion in the industrial sector. Although an aggregate demand and supply imbalance persisted and the economy continued to experience excess demand pressures, the increase in the cost of living index was held to 5 per cent, primarily through reliance on administered prices.

The Iranian authorities have maintained a policy of fiscal restraint into $1976 / 77$, and guidelines were established with the intention of again holding the annual growth in central government expenditures to about 20 per cent. However, as oil revenues were not anticipated to increase notably, a central government budget deficit was projected, to be financed through a drawdown of government deposits with the banking system and reliance on bank credits. Despite this turnaround in the fiscal position, financial restraint, including a reduced growth in private sector credit, was anticipated to yield a further slowing in monetary expansion to about 30 per cent and a continued easing of pressures on domestic resources and prices.

In the case of Saudi Arabia, the government budget for 1975/76 called for more than a threefold increase in expenditures over those for $1974 / 75$, with the largest part of the increase appropriated for development projects. Actual fiscal and monetary data are not yet available for 1975/76; however, government expenditures are believed to have fallen short of the budget estimates mainly because of the existing physical bottlenecks. While a large proportion of expenditures were accounted for by direct payments abroad, public sector net domestic spending increased considerably, thereby exerting a further expansionary impact on domestic liquidity which continued to grow at a rapid rate in the early part of the year despite an increase in the private sector

Table 4

Saudi Arabia: factors affecting changes in money and quasi-money (In billions of U.S. dollars)

\begin{tabular}{|c|c|c|c|}
\hline Fiscal years & $1972 / 73$ & $1973 / 74$ & $1974 / 75$ \\
\hline \multicolumn{4}{|l|}{$\begin{array}{l}\text { Changes in } \\
\text { money and }\end{array}$} \\
\hline $\begin{array}{l}\text { Government net } \\
\text { domestic } \\
\text { expenditures }\end{array}$ & 1.70 & 2.95 & 5.81 \\
\hline $\begin{array}{l}\text { Monetary } \\
\text { impact of }\end{array}$ & & & \\
\hline $\begin{array}{l}\text { private sector } \\
\text { Bank claims on } \\
\text { private sec- } \\
\text { tor (increase }\end{array}$ & -1.07 & -2.11 & -4.00 \\
\hline+1 & 0.03 & 0.39 & 0.62 \\
\hline $\begin{array}{l}\text { Private sector } \\
\text { balance of } \\
\text { payments }\end{array}$ & .. & & \\
\hline (deficit -$)^{3}$ & -1.10 & -2.50 & -4.62 \\
\hline $\begin{array}{l}\text { Changes in net } \\
\text { unclassified } \\
\text { bank liabilities }\end{array}$ & -0.20 & -0.14 & -0.31 \\
\hline \multicolumn{4}{|c|}{$\begin{array}{l}\text { Source: Fund staff calculations based on data } \\
\text { provided by the Saudi Arabian authorities. } \\
\text { 1 See foothote 1, Table } 3 \text {. } \\
\text { 2 Derived as the sum of public sector net } \\
\text { foreign exchange receipts, as recorded in the } \\
\text { balance of payments statement, and the increase } \\
\text { in net bank claims on the public sector. } \\
\text { 3 Includes net errors and omissions of the } \\
\text { balance of payments statement. }\end{array}$} \\
\hline
\end{tabular}

balance of payments deficit. Prices continued to rise sharply in late 1975 and early 1976.

Saudi Arabia's financial policies for $1976 / 77$ seek to moderate the rate of price continued on page 42 


\section{Heinz Handler}

The term "oil producing countries" has emerged in the wake of the oil crisis of 1973. It has been used to cover the oil exporters in the Middle East, Asia, Africa, and South America. Although these countries are heterogeneous as regards their standards of living, they have in common an economic structure that is still in a preindustrial stage. In general, they lack a production structure that would enable them to spend substantial amounts of their oil revenues domestically. The situation is completely different when an industrial country is an oil producer. In this article the example of Norway is taken to discuss the problems created by the development of a crude oil and natural gas sector in a highly developed economy.

With the emergence of an offshore oil sector at the beginning of this decade, Norway has entered a new development stage. Its industrial development came at the turn of the century when its economy, previously based largely on the production of fish, timber, and iron ore, started to utilize its huge hydropower resources for the establishment of a highly capitalintensive metallurgical and chemical industry. At the same time the merchant fleet was expanded and modernized. The last two decades have been characterized by diversification of production and increasing integration into the world economy. The next decade and beyond is likely to be greatly influenced by the developments in Norway's new offshore oil sector.

Unless technical difficulties cause delays, the volume of oil and gas production in Norway is expected to rise to some 78 million tons of crude oil equivalent in 1980, from about 9.3 million tons in 1975. By 1982, when the oil and gas fields so far explored will be producing at full capacity, total oil and gas output is expected to reach some 90 million tons of oil equivalent a year, of which about one third would be contributed by natural gas. The recoverable reserves of oil and gas' south of the 62 nd parallel (latitude 62 degrees north) are estimated at 2 to 3 billion tons of oil equivalent and would last until the turn of the century. If reserves north of the 62 nd parallel prove to be recoverable, the production period could last much longer.

Even at its peak in the early 1980s, production is unlikely to exceed 2 per cent of estimated world petroleum output, or about 7 per cent of European oil consumption. Norway will therefore not be able to exert a significant influence on the international price of oil. The margin of oil prices over production costs is an important determinant of the duration of the Norwegian "oil era" apart from the size of the recoverable oil reserves. At present, production costs of US\$5-6 a barrel in the less "expensive" oilfields in the Norwegian North Sea sector leave a comfortable margin at current market prices. Average production costs in the North Sea would, however, increase if exploitation was to extend to oilfields located in deeper waters.

The investment required to develop the new petroleum sector rose sharply from $\mathrm{NKr} 0.3$ billion in 1970 to $\mathrm{NKr} 5.5$ billion in 1975. Owing to its high international credit standing, the prospective large income from oil production, and the involvement of foreign oil companies, Norway was able to finance the investment fully through medium-term and longterm foreign loans. As much of the investment consisted of imported equipment, Norway's current account deficit in this period averaged over 4 per cent of gross domestic product (GDP), well above the $1^{1 / 2}$ per cent recorded in the 1960 s. About one third of the oil equipment required was produced in Norway, particularly drilling platforms, and this activity was an important expansionary force in the economy.

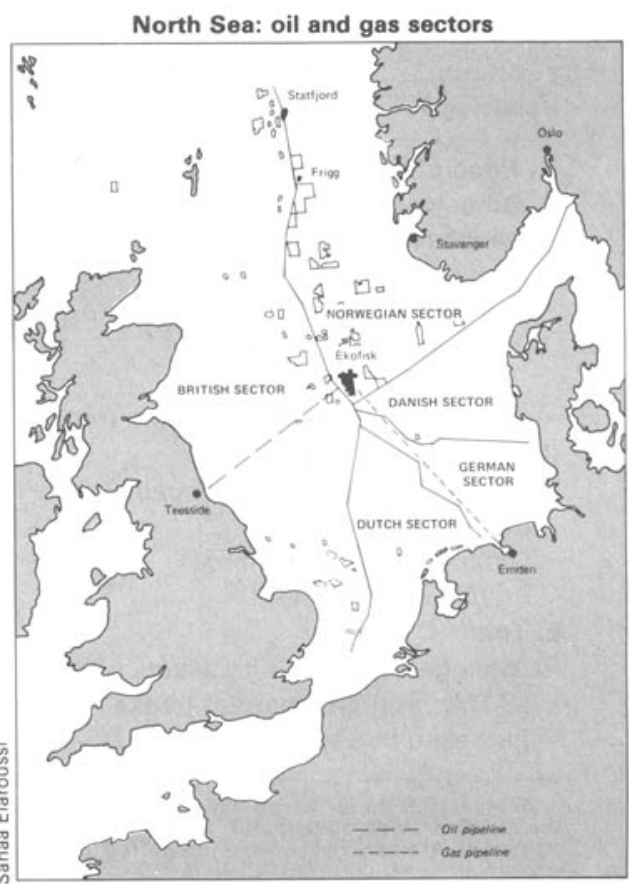

With the attainment of full-scale production of oil and the shift to being a net oil exporter from the latter part of 1975, Norway will substantially increase its per capita income and transform its traditional current account deficit into a large surplus during the second half of the 1970s. This surplus will be maintained even though oil revenue is likely to be used for raising the level of domestic consumption and investment; it will enable Norway to reduce its foreign indebtedness and to increase its investment abroad and 
its foreign aid. The oil revenue will accrue to a large extent to the Government via tax and royalty receipts as well as through government ownership of the Statoil company, thus enabling the Government to maintain control over the impact of the oil sector on the economy.

\section{Oil policy}

An important aim of Norway's longterm oil policy is to integrate the oil sector into the traditional structure of the economy. Disturbances are inevitable insofar as cost and price increases are part of the process of establishing the oil sector, while contracting parts of the economy (releasing labor to the oil sector) are hardly likely to be able to reduce wages and prices. The impact of these disturbances is likely to affect almost every sector of the economy but it will be most pronounced in a few branches and markets, particularly in industries exposed to foreign competition.

Oil policy has been based largely on an assessment of Norway's petroleum reserves in the North Sea and the expected long-term development in the international price of oil. The authorities' decision to

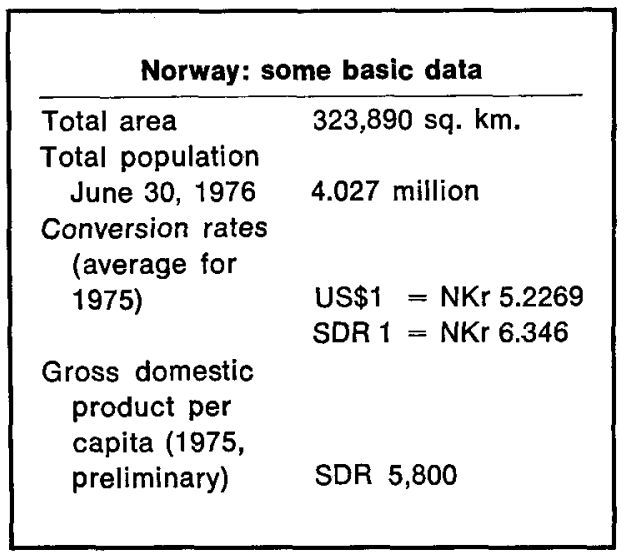

adopt a "go-slow" policy in oil exploitation has been determined by the desire to prevent rapid structural change and undesirable environmental damage. In this way, the initial adverse impact on other sectors of the economy can be softened, and the Norwegian "oil age" stretched. However, the policy also increases the period of risk of a future decline in the price of oil relative to the general price level.

Another element in Norway's oil policy is the extensive government control of all activities connected with the new oil sector. The taxation of oil companies will assure the large government revenues needed to increase the intended public sector investment, to enable the Government to finance regional and labor market projects and to reduce direct taxation in the lower-income brackets.

The division of public sector oil revenue-the largest part of the revenue from oil operations-between foreign and domestic uses will influence the degree of pressure on domestic resources (as reflected in domestic costs and prices), which may result in conditions of full employment from spending the increasing oil revenue. An essential aim of short-term and medium-term policies is to moderate these pressures; but this will become more difficult to achieve as Norway's current surplus rises. The growing surplus will increase the income expectations of the private sector, which will be expressed in higher wage claims, and this in turn will add to the pressure for a policy of spending public revenue in Norway rather than abroad.

The Government (in its report Petroleum Industry in Norwegian Society) has indicated that about half the public revenue from the petroleum sector may be

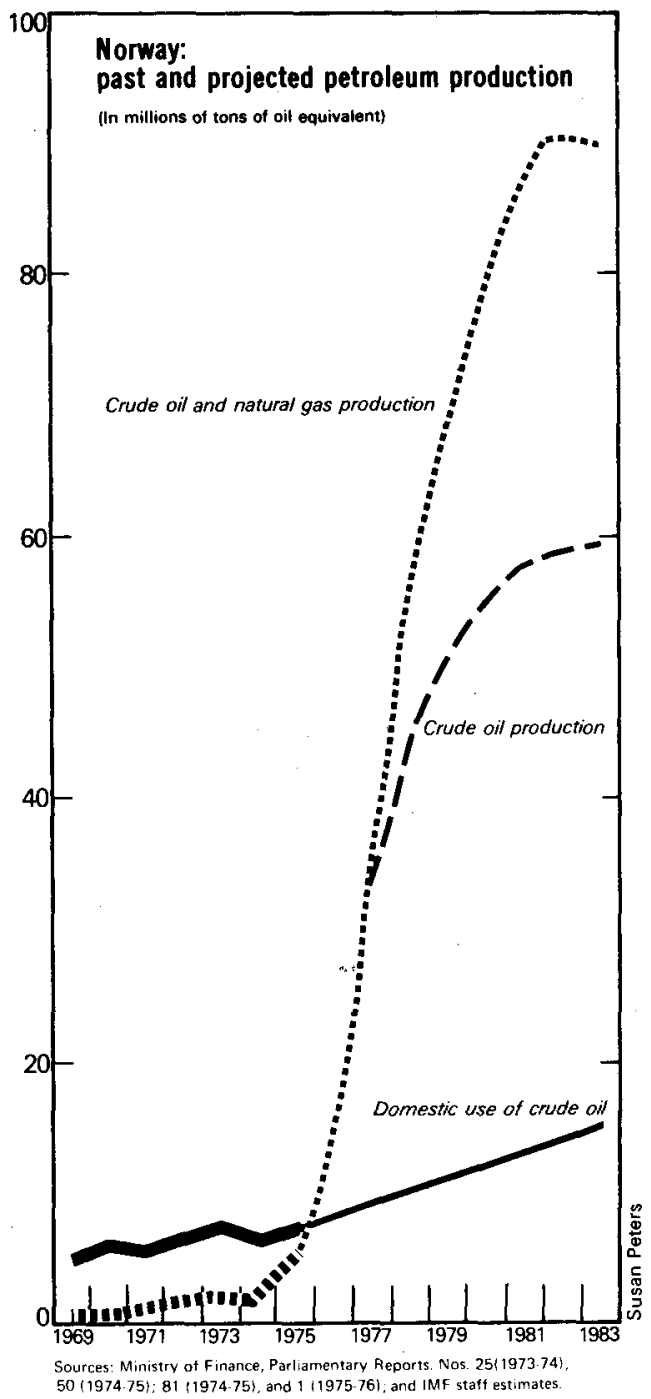

used domestically, but only a part of this will be spent on goods and services. Part will be used to ease personal taxationcuts in personal income tax rates were introduced in the budgets for 1975 and 1976-and to increase transfer payments to the private sector. The Government also plans to support certain investment 
projects in the private sector, most prominently in residential construction.

There are various options that could govern the use of public oil revenue spent abroad. The choices will not become urgent until about 1978. For a number of years after that, oil income will be largely earmarked to repay the foreign debt accumulated for offshore investments. Subsequently, it may be used to buy out foreign interests in companies operating in Norway, which is a form of capital export. Capital exports could also include lending to international organizations dealing with multilateral development aid. The Norwegian Parliament has declared its aim to expand official development assistance to 1 per cent of GDP by 1978. Thereafter, official aid is likely to rise faster than GDP.

The Norwegian Government also plans to acquire production facilities abroad as investments that could provide a return similar to that of domestic export enterprises without, however, absorbing domestic resources. In addition, foreign investments can be considered as a safeguard for the years after the end of the oil period.

\section{Demand for labor}

With the development of offshore oil, the demand for labor in Norway will increase both directly and indirectly. The direct increase will be in the oil sector, and those sectors providing it with goods and services. The indirect increase will occur as a result of the higher overall economic activity in the regions with oil-related industries. Moreover, in the economy as a whole, the demand for labor is likely to rise via the domestic spending of public oil revenue.

The direct effect of petroleum activities on the demand for labor has been small to date. In August 1975, a total of 20,700 persons (including some 2,500 foreigners) was employed in all petroleum-related operations; this accounts for not much more than 1 per cent of the Norwegian labor force. Up to 1980 , an increase to about 25,000 employees is envisaged. Between 1974 and 1980 Norway's total supply of labor is expected to increase by 75,000 persons; over the same period, the sectors protected against foreign competition plus the oil sector will require about 95,000 to 110,000 additional persons (disregarding the indirect effects of the use of oil revenues). The loss of labor in the industries "exposed" to foreign competition will thus be some 20,000 to 35,000 persons (Table 1). Furthermore, the domestic spending of oil revenue is expected to create 7,000 to 8,000 additional jobs in the protected sectors for each NKr 1 billion spent. Although these figures can only be approximate, they indicate the pressures that are likely to be felt in the labor market and the strength

\begin{tabular}{|l|l|}
\hline \multicolumn{3}{|c|}{ Table 1 } \\
Estimated cumulative change in \\
employment 1974-80 1 \\
(In thousands of man-years)
\end{tabular}

of the incentive to substitute capital for labor and to import labor-intensive goods from abroad.

\section{Supply and demand}

The gradual development of the petroleum sector is changing the relative importance of production factors for the Norwegian economy. Certain basic input

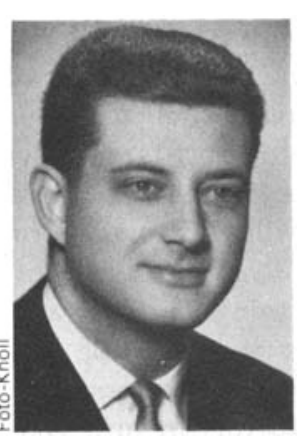

Heinz Handler versity of Vienna, he was a scholar at the Institute for Advanced Studies, Vienna, before joining the Austrian Institute for Economic Research in 1968 . He returned to this Institute after having served for nearly three years in the Fund. He has published several articles on foreign trade problems. goods (oil, oil-based energy) are becoming relatively more abundant, and labor scarcer. Changes in the structure of production will inevitably follow, and friction will be unavoidable.

A major concern of long-term policy is to hold down the share of oil-dependent activities in overall production. Although the oil reserves in the Norwegian part of the North Sea seem large enough to assure a yield at least until the turn of the century, an economy based on the extraction and refinement of a single commodity is vulnerable-the international oil market in particular cannot be regarded as stable -and considerable uncertainty attaches to predictions of demand and price developments for crude oil over a longer period.

Some of the oil-related structural changes in the economy have already taken place. Most notably, Norwegian industry has developed new devices for large-scale exploration and production of oil in deep water that are already being exported to other countries. Norwegian shipyards have switched mainly to the production of mobile drilling rigs, and the construction sector supplies the newly developed concrete platforms. With the production of oil and its landing in Norway on a large scale, the development of additional refining capacity and of petrochemical plants will follow.

Petroleum development will change the production and export structure in favor of raw materials, thus reversing the pronounced postwar trend toward a rising share of manufactured goods, from 54.9 per cent of the value of total exports excluding ships, in the period 1955-57, to 68.7 per cent in the period 1972-74. The establishment of additional refining capacity and of petrochemical plants will retard the rise in the share of crude oil in total exports. In the second half of the 1970s, exports are expected to become the demand component with the fastest growth, and thei: share in total demand (measured in 1974 prices) is expected to rise from about 31 per cent in 1974 to about 38.5 per cent in 1980 . With a projected average growth in the volume of exports between 1974 and 1980 of about 10 per cent a year, the contribution of the real foreign balance to aggregate demand would rise from -2.3 per cent in 1974 to almost 9 per cent in 1980 . This will be entirely due to the contribution of the oil sector, while the deficit on the balance of non-oil goods and services is expected to increase, largely because of the increase in imports induced by the use of oil revenue. Compared with the increase in the relative importance of foreign demand, 
Table 2

Demand and supply growth, 1950-80

(Annual percentage changes) ${ }^{\text {t }}$

\begin{tabular}{|c|c|c|c|c|}
\hline & \multirow[b]{2}{*}{$1950-60$} & \multirow[b]{2}{*}{$1960-70$} & \multirow[b]{2}{*}{$1970-74$} & \multirow{2}{*}{$\frac{\text { Estimate }}{1974-80}$} \\
\hline & & & & \\
\hline \multicolumn{5}{|l|}{ Demand components } \\
\hline Private consumption & 3.0 & 4.4 & 3.5 & 4.7 \\
\hline Public consumption & 5.1 & 5.3 & 4.5 & 4.0 \\
\hline Gross investment & 3.7 & 5.6 & 6.2 & 3.0 \\
\hline Private & (3.4) & (5.4) & (6.1) & (2.2) \\
\hline Public & $(5.8)$ & (6.6) & (6.8) & (7.3) \\
\hline Total domestic demand & 3.4 & 4.9 & 4.5 & 4.0 \\
\hline Exports & 6.5 & $\underline{7.6}$ & 5.8 & 9.4 \\
\hline Total demand $=$ total supply & $\overline{4.3}$ & $\overline{5.7}$ & 4.8 & 5.9 \\
\hline \multicolumn{5}{|l|}{ Supply components } \\
\hline imports & 5.3 & 7.9 & 6.0 & 3.8 \\
\hline $\begin{array}{l}\text { Gross domestic product } \\
\text { (GDP, excluding shipping and oil sectors) }\end{array}$ & 3.9 & 4.7 & $\begin{array}{c}4.3 \\
(4.2)\end{array}$ & $\begin{array}{c}6.8 \\
(4.0)\end{array}$ \\
\hline \multicolumn{5}{|c|}{$\begin{array}{l}\text { Sources: Ministry of Finance, Stortingsmelding Nr. } 50 \text { (1974-75); Stortingsmelding Nr. } 1 \text { (1975- } \\
\text { 76); Central Bureau of Statistics, Statistisk Ukehefte; Nasjonalregnskap 1950-66, 1954-70; and } \\
\text { iMF staff calculations. } \\
\text {, Growth rates for the period } 1950-70 \text { are calculated from the old Norwegian system of } \\
\text { national accounts. } \\
\ldots \text { indicates data not available. }\end{array}$} \\
\hline
\end{tabular}

possible replacement by a surplus as early as 1978 . Subject to the great uncertainties of tuture export prices, petroleum exports are estimated to account for about 40 per cent of total nominal merchandise exports by 1980 (compared with $1 \frac{1 / 2}{2}$ per cent in 1974); by contrast, the share of capital goods imported by the oil sector in total merchandise imports is expected to drop from 9 per cent in 1974 to 3 per cent in 1980. Exports of offshore services, such as technology of oil and gas transportation and drilling, will also increase sharply. Offsetting factors will be the still rising interest payments for investment in the oil sector financed by foreign credit; and the envisaged increase in official development aid. Developments in the oil sector will also influence the balance of payments indirectly via the rise in imports induced by higher incomes, which will also serve as an equilibrating force on the domestic markets for goods and money.

After 1978, the current account surplus changes in the structure of domestic demand are expected to be minor (see Table 2).

\section{Incomes, costs and prices}

The shifts in demand and supply on the goods and labor markets, induced by the oil operations, are giving rise to changes in the structure of incomes, production costs, and prices. The ability of non-oil industries to adjust wage rates to the higher level paid in the oil sector will depend on the price elasticity of demand for their product. Norwegian industries exposed to foreign competition are, as a rule, price takers-they are not in a position to affect world prices. Consequently, they will not be able to mark up prices and, as a result, will tend to lose employees. There is greater freedom in the pricing behavior of sheltered industries, which usually find it easier to pass on higher costs to consumers.

Public income from offshore oil operations will vary primarily with the market price of oil, the volume of production, the degree of government participation in extraction, and the structure of taxes. Taking account only of the Ekofisk production (see map), where exploitation started in 1971, the cumulative public oil revenue over the period 1975 to 1980 could amount to about NKr 60-65 billion (in 1974 prices).

Imports of capital goods for the offshore oil sector, which rose steadily from about NKr 1.1 billion in 1972 to NKr 6.4

Table 3

Current account development

(In millions of Norwegian kroner)

\begin{tabular}{|c|c|c|c|c|c|}
\hline & 1972 & 1973 & 1974 & 1975 & $\frac{\text { Forecast }}{1980}$ \\
\hline Petroleum exports & 244 & 237 & 490 & 3,375 & 37,230 \\
\hline $\begin{array}{l}\text { Exports of new ships and } \\
\text { drilling platforms } \\
\text { Imports of oil sector }\end{array}$ & 1,316 & 1,485 & 2,008 & 4,575 & 2,500 \\
\hline equipment & $-1,118$ & $-3,018$ & $-4,730$ & $-6,443$ & $-7,600$ \\
\hline Net imports of other ships 1 & $-1,236$ & $-2,085$ & -887 & $-3,637$ & $-2,100$ \\
\hline Other merchandise (net) & $-6,652$ & $-7,599$ & $-12,738$ & $-16,699$ & $-21,130$ \\
\hline Trade balance & $-7,446$ & $-10,980$ & $-15,857$ & $-18,829$ & 8,900 \\
\hline Exports of oil sector services & - & 48 & 338 & 562 & 5,600 \\
\hline Interest payments abroad & $-1,901$ & $-2,405$ & $-3,802$ & $-3,695$ & \\
\hline $\begin{array}{l}\text { Other services and } \\
\text { transfers (net) }\end{array}$ & 8,960 & 11,327 & 12,496 & 8,692 & 5,500 \\
\hline $\begin{array}{l}\text { Current account } \\
\text { Of which: } \\
\text { Oil sector }\end{array}$ & -387 & $-2,010$ & $-6,825$ & $-13,270$ & 20,000 \\
\hline $\begin{array}{c}\text { transactions } 2 \\
\text { Other transactions }\end{array}$ & $\begin{array}{r}(-874) \\
(487)\end{array}$ & $\begin{array}{r}(-2,733) \\
(723)\end{array}$ & $\begin{array}{l}(-3,902) \\
(-2,923)\end{array}$ & $\begin{array}{r}(-2,506) \\
(-10,764)\end{array}$ & $\begin{array}{r}(35,230) \\
(-15,230)\end{array}$ \\
\hline
\end{tabular}

Sources: Central Bureau of Statistics, Statistisk Ukehefte; Ministry of Finance, Revised National Budgets 1974, 1975, and 1976, and National Budget 1976; and Stortingsmelding Nr. 50 (1974-75).

1 Exports of used ships minus imports of all ships.

2 Petroleum exports, exports of oil sector services, and imports of oil sector equipment.

billion in 1975 , contributed significantly to a persistent sharp increase in the current account deficit, from NKr 0.4 billion in 1972 to NKr 13.3 billion in 1975 (see Table 3). The expected leveling out of oil sector investment after 1976 and the sharp stepping up of oil production over the next few years will result in a gradual reduction in the current deficit and its is projected to increase rapidly, to about NKr 20 billion by 1980. The value of oil and gas exports in current prices for that year may amount to some NKr 37 billion. Future current account surpluses are likely to be used largely for capital exports, first in the form of external debt repayments, and in due course in the form of investment abroad. A close official control 
of such investment is necessary to ensure that investment income can replace income from oil operations if and when the latter declines.

\section{Outlook and policy issues}

The development of the Norwegian economy beyond the early 1980s will depend on two factors: the successful management of the transitional period until the new petroleum sector is fully integrated into the economy; and the duration of the Norwegian oil age. How long the oil age lasts will depend on the economic exploitability of oil and gas, which turns on the interaction of the international price of energy relative to the cost of exploration and exploitation of the continental shelf. The existing "go

\section{Other North Sea oil and gas producers}

Besides Norway, four other countries (Denmark, the Federal Republic of Germany, the Netherlands, and the United Kingdom) have jurisdiction over sectors of the North Sea (see map).

The U.K. sector is the largest (Norway controls the second largest). Production in this sector started in 1975 with a total of 1.1 million tons of oil and about 31 million tons of oil equivalent of natural gas. Production of oil is expected to rise to some 15-20 million tons in 1976, about one fifth of domestic oil consumption. By 1980 oil production is predicted to reach 95-115 million tons-probably more than domestic oil use in the United Kingdom. Total recoverable reserves of oil and gas from currently designated areas are estimated at some 4,200 million to 5,700 million tons of oil equivalent (of which 3,000-4,500 million tons constitute oil). At the envisaged rate of extraction in 1980, the oil reserves would last until about the first or second decade of the next century.

In 1975 the North Sea activities of the United Kingdom had a considerable impact on the balance of payments. Export earnings and import savings together amounted to some 11.9 billion or 1.8 per cent of gross national product. As in Norway, the direct effect of the offshore sector on employment has been small: in 1975 somewhat more than 6,000 persons (out of a labor force of roughly 23 million) were employed in offshore activities. Government influence over the U.K. oil and gas sector was ensured by several laws adopted in 1975. These provide for the control of exploration and production of petroleum and natural gas, the taxation of oil companies and the establishment of the British National Oil Corporation, which will be a major instrument of direct government participation in oilfields.

In the Netherlands the major natural gas finds were made on the continent. In the late 1960 s and early 1970 s the energy policy of the Netherlands aimed at a rapid depletion of the gas resources, so as to avoid the risk that alternative forms of energy would make natural gas obsolete. Most of the gas finds, including future finds, were contracted under the influence of the Government for export at prices that turned out to be low compared with the energy price level after the oil crisis. The Netherlands subsequently reappraised its energy policy. Because of lack of major new gas or oil discoveries, a "go-slow" policy was adopted to conserve existing reserves. In addition, most new contracts for the delivery of natural gas now include some sort of a price-cost indexation clause. The new policy attempts to ensure that production from the gas reserves, presently estimated at some 2,100 million tons of oil equivalent, would last until the turn of the century. Annual production is seen to rise from about 82 million tons of oil equivalent in 1975 to a peak of 93 million tons in 1978 and to decline gradually thereafter. Exports are also expected to reach a peak of some 49 million tons of oil equivalent in 1978 .

Since 1974 the Netherlands has been a net exporter of gas and oil in volume terms, while the energy balance in value terms remained negative as a consequence of the relatively low export prices of gas. Since 1975 the Government is entitled to collect 90 per cent of the profit resulting from increases in the price of natural gas. In 1976 the nontax revenue of the Government from gas sales is estimated at some 5.5 billion guilders or $71 / 2$ per cent of estimated total government revenue.

slow" policy is in part an expression of the uncertainties involved in the petroleum project and in part the result of a judgment that the impact of the oil sector on the rest of the economy will be easier to manage the longer the period over which it is spread.

For the longer term, the authorities are evaluating the implications of three sets of alternative assumptions. A "highgrowth" alternative assumes a gradual increase in petroleum output from 90 million tons of oil equivalent annually at the beginning of the 1980 s to 180 million tons in the year 2000, and a strong increase in aggregate demand (compared with that under the other alternatives), resulting in an annual growth rate of real GDP of 4.3 per cent. A "medium-growth" alternative assumes unchanged production of petroleum between the early $1980 \mathrm{~s}$ and the end of the century and a more moderate growth in aggregate demand, with an average annual GDP growth of 3.7 per cent. Under a "low-growth" alternative a reduction of oil and gas production by 1990 to about 50 million tons of oil equivalent and a comparatively slow growth in total demand is assumed; this results in an estimated annual average GDP growth of only 2.6 per cent. All three projections have in common that the growth in GDP in the 1980s and 1990s will be considerably lower than in the second half of the 1970s, largely owing to the projected slower expansion of exports that are expected to decelerate to a rate below that of imports. Assuming no drastic change in the terms of trade, the Norwegian current account surplus is thus projected to diminish and eventually disappear under all three projections by the turn of the century.

In the interim period, a policy mix will emerge that retains the merits of a highly diversified economy while allowing domestic living standards to rise and to be maintained on a high level beyond the passing of the oil age. The pace at which the real income expectations of the population rise and the manner in which they are met are critical elements in the transition. Should present controls of immigration from outside the Nordic labor market be maintained, the increase in wage costs can be contained if an increase in real disposable income is achieved through lowering taxes. To the extent that a large current account surplus remains, it will have to be offset by capital exports if domestic demand management is to be successful within a framework of a relatively stable exchange rate policy. 


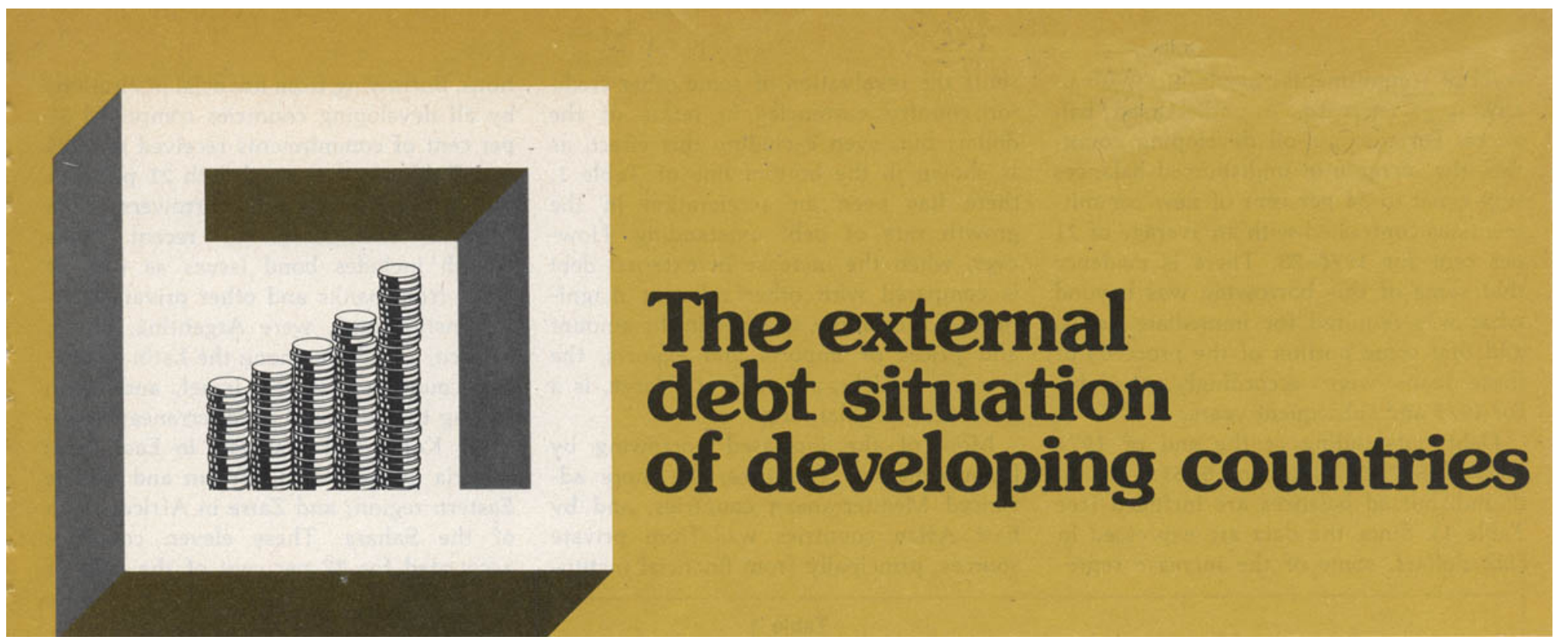

Developing countries ran substantially increased balance of payments deficits following the recession in the industrial countries and major changes in international prices. This article, based on world debt data for 1974 which have been published recently by the World Bank, examines the associated increase in borrowing by certain groups of developing countries, both from official and private sources.

Thomas M. Klein

A period of steady economic progress for developing countries was abruptly interrupted by the large adverse changes of their terms of trade and by the recession in industrialized countries. With the decline in export prices of primary products and the continued rise in the price of imported manufactured goods and other essential commodities, the per capita growth rate of non-oil developing countries (adjusted for the income effects of the terms of trade) is estimated to have been negligible in 1975, after rising at a rate of about 2 per cent per annum during the $1960 \mathrm{~s}$ and at about $2 \frac{1 / 2}{2}$ per cent per annum from 1971 to 1974 .

A number of developing countries attempted to cushion the fall of investment and consumption by permitting and sustaining very large current account balance of payments deficits in 1974 and 1975 by drawing upon reserves accumulated in the early 1970s and by increased use of foreign loans. In the absence of this inflow of external resources, standards of living and long-term development programs could not have been maintained. Furthermore, the efforts of these countries to limit the reduction of their import volumes had a significant positive effect on exports and growth in the industrial countries.

The source of information for this article is the annual summary of statistics on external public debt (including publicly guaranteed debt) reported to the World Bank by developing member countries. While the data do not go beyond 1974, they do give a first indication as to how widespread among developing countries this ability to borrow was and what has been the impact of this new borrowing on the structure of their external debt.

\section{Credit sources}

New commitments received by the public sector of developing countries amounted to $\$ 36.33$ billion in 1974 , an increase by more than one third over the 1973 level of $\$ 27$ billion. A small number of countries accounted for the bulk of this $\$ 9$ billion increase. In Latin America, Argentina and Brazil accounted for $\$ 1.1$ billion each, while Peru's increased borrowing was $\$ 0.3$ billion. Among the advanced Mediterranean countries, Spain and $\mathrm{Yu}$ goslavia secured additional commitments of about $\$ 0.9$ billion each. Five East Asian countries borrowed $\$ 3.8$ billion more in 1974 than in 1973. In the South Asian region, Pakistan's borrowings were up by almost $\$ 1.0$ billion; India's by $\$ 0.4$ billion. Two oil exporting developing countries, Algeria and Iran, which have been major borrowers in the past, reduced their new commitments in 1974 by $\$ 2.5$ billion (see footnote 1 to Table 1 for definitions of regions).

The $\$ 36$ billion of new commitments received in 1974 was accompanied by a net resource flow of about $\$ 18$ billion (measured by the increase in debt outstanding from end-1973 to end-1974). Net flows are always less than commitments for any year; disbursements received from 1974 and earlier commitments were partly offset by repayment of existing loans. However, in 1974 there was another reason why net flows were well below the 
Ieve or commirments: namely, an unusually large increase in undisbursed balances. For the non-oil developing countries, the increase in undisbursed balances was equal to 34 per cent of new commitments as contrasted with an average of 21 per cent for 1970-73. There is evidence that some of this borrowing was beyond what was required for immediate needs, and that some portion of the proceeds of these loans were, accordingly, available for 1975 and subsequent years.

Debt outstanding at the end of 1974 reached $\$ 105.5$ billion, or $\$ 151.4$ billion if undisbursed balances are included (see Table 1). Since the data are expressed in U.S. dollars, some of the increase repre- sents the revaluation of some other creditor country currencies in terms of the dollar; but, even excluding this effect, as is shown in the bottom line of Table 1 , there has been an acceleration in the growth rate of debt outstanding. However, when the increase in external debt is compared with other relevant magnitudes, for example, changes in the amount and prices of imports and exports, the increase in debt, although still large, is a good deal less alarming.

Most of the increased borrowing by Latin American countries, the more advanced Mediterranean countries, and by East Asian countries was from private sources, principally from financial institu- tions. Borrowing from financial institutions by all developing countries comprised 38 per cent of commitments received in $\mathbf{1 9 7 4}$ (see Table 2), compared with 21 per cent in 1970. The largest borrowers from financial institutions in recent years (which includes bond issues as well as loans from banks and other private lending institutions), were Argentina, Brazil, Mexico, and Peru among the Latin American countries; Greece, Israel, and Spain among the advanced Mediterranean countries; Korea and Malaysia in East Asia; Algeria in the North African and Middle Eastern region; and Zaïre in Africa, south of the Sahara. These eleven countries accounted for 72 per cent of the debt of

Table 1

Foreign borrowing and external public debt of 86 developing countries, 1972-74 (In billions of U.S. dollars)

\begin{tabular}{|c|c|c|c|c|c|c|c|}
\hline & \multicolumn{3}{|c|}{ Commitments received } & \multicolumn{3}{|c|}{$\begin{array}{l}\text { Debt outstanding } \\
\text { disbursed only } \\
\text { (Year-end) }\end{array}$} & \multirow{2}{*}{$\begin{array}{c}\begin{array}{c}\text { Debt outstanding } \\
\text { incl. undisbursed } \\
\text { (Year-end) }\end{array} \\
1974\end{array}$} \\
\hline & 1972 & 1973 & 1974 & 1972 & 1973 & 1974 & \\
\hline \multicolumn{8}{|l|}{ By geographical region' } \\
\hline Africa, south of Sahara & 1.75 & 3.52 & 3.60 & 6.22 & 7.66 & 9.31 & 15.96 \\
\hline East Asia and Pacific & 3.21 & 3.53 & 7.37 & 8.80 & 11.66 & 14.15 & 23.76 \\
\hline Latin America and the Caribbean & 7.40 & 9.07 & 11.53 & 21.86 & 26.93 & 34.57 & 45.38 \\
\hline North Africa and the Middle East & 3.31 & 5.65 & 4.72 & 9.61 & 12.47 & 14.18 & 22.79 \\
\hline South Asia & 1.68 & 2.56 & 4.23 & 14.22 & 15.73 & 17.47 & 23.38 \\
\hline More advanced Mediterranean & 2.81 & 2.69 & 4.88 & 10.88 & 13.03 & 15.85 & 20.12 \\
\hline $\begin{array}{l}\text { Total } \\
\text { By income group? }\end{array}$ & 20.16 & 27.01 & 36.33 & 72.59 & 87.49 & 105.53 & 151.40 \\
\hline Oil exporters & 4.00 & 6.76 & 4.17 & 12.02 & 15.64 & 17.71 & 25.92 \\
\hline Higher-income countries & 10.68 & 12.48 & 18.78 & 33.37 & 40.92 & 52.18 & 70.76 \\
\hline Middle-income countries & 2.97 & 3.37 & 6.25 & 9.95 & 11.47 & 13.49 & 22.08 \\
\hline Lower-income countries & 2.51 & 4.40 & 7.14 & 17.24 & 19.47 & 22.15 & 32.64 \\
\hline Total & 20.16 & $\overline{27.01}$ & $\overline{36.33}$ & $\overline{72.59}$ & $\overline{87.49}$ & $\overline{105.53}$ & 151.40 \\
\hline
\end{tabular}

By type of credit

Official sources

Loans from governments

Concessional

Other

Subtotal

International organizations

Total, official sources

Private sources

Financial institutions

Suppliers' credits

Other $^{3}$

Total, private sources

Total, all sources

\begin{tabular}{|c|c|}
\hline $\begin{array}{l}3.99 \\
3.93\end{array}$ & \\
\hline 7.92 & \\
\hline 3.77 & \\
\hline 11.69 & \\
\hline 6.43 & \\
\hline 2.04 & \\
\hline 0.00 & \\
\hline 8.47 & \\
\hline$\overline{20.16}$ & \\
\hline
\end{tabular}

\begin{tabular}{rrr}
3.81 & 5.99 \\
5.00 & & 5.26 \\
\hline 8.81 & & 11.25 \\
4.92 & & 6.59 \\
\hline 13.73 & & $\frac{17.84}{17}$
\end{tabular}

23.31

13.55

$\overline{38.86}$

10.88

$\overline{47.74}$

13.90

4.59

0.00

18.49

$\overline{36.33}$

14.79

14.79
8.94

$\frac{1.12}{24.85}$

$\overline{72.59}$

$\begin{array}{lll}29.79 & & 40.83 \\ 18.72 & & 25.94 \\ 48.51 & & 66.77 \\ 15.83 & & 30.24 \\ 64.35 & & 97.01\end{array}$

55.85

20.88

9.91

$\frac{0.84}{31.63}$

$\overline{87.49}$

Total, adjusted for exchange rate changes since the Smithsonian Agreement (December 1971)

Amounts

Increase from previous year (\%)

85.67

15.8

17.8

28.65

11.22

36.86

16.22

1.31

1.31

54.39

$\overline{105.53}$

151.40

Source: Data reported to the World Bank on external public and publicly guaranteed debt with an original maturity of more than one year, as published in World Debt Tables EC-167/76.

'These regions are as follows: munity; Ethiopia; Gabon; The Gambia; Ghana; Ivon Coast; Kenya; Lesotho; Liberia; Medagascar; Malawi; Mali; Mauritania; Mauritius; Niger; Nigeria; Rwanda; Senegal; Sierra Leone; Somalia; Sudan; Swaziland; Tanzania; Tog o; Uganda; Upper Volta; Zaire; Zambia.

Latin America and the Caribbean-Argentina; Bolivia; Brazil; Chile; Colombia; Costa Rica; Dominican Republic; Ecuador; El Salvador; Guatemala;

Guyana; Honduras; Jamaica; Mexico; Nicaragua; Panama; Paraguay; Peru; Trinidad and Tobago; Uruguay; Venezuela.

North Africa and Middlo East-Afghanistan; Algeria; Cyprus; Egypt; Iran; Iraq; Jordan; Morocco; Syrian Arab Republic; Tunisia.

South Asia-Bangladesh; Burma; India; Pakistan; Sri Lanka.

More advanced Mediterranean countries-Greece; Israel; Malta; Portugal; Spain; Turkey; Yugoslavia.

2 The income groups are divided according to annual per capita gross national product as given in the World Bank Atlas, 1975 edition: lower income,

below \$200; middle income, \$200-\$499; higher income $\$ 500-1,999$

${ }^{3}$ Commitment figures shown here exclude the increase in public debt resulting from the nationalization of foreign properties. 
developing countries owed to financial institutions at the end of 1974.

Countries have been able to attract funds from private financial institutions because they had, at the time of borrowing, extremely attractive prospects either for the production and export of primary products (such as, for example, Algeria and Zaïre) or because their economic prospects more generally were thought to be good, with production and exports, particularly of manufactured goods, grow ing rapidly (for example, Mexico, Greece, Spain, Yugoslavia, and Korea). In addition, some lending was related to direct investment. There are some unique situations among the countries listed in Table 2 , such as Panama (a financial entrepôt center) and the Sudan (a recipient of aid from the Organization of Petroleum Exporting Countries - OPEC - through guaranteed commercial bank loans rather than through direct loans from governments).

Lending to developing countries has continued to grow through mid-1976, according to information on publicized Eurocurrency lending and international bond issues. Such commitments were $\$ 13.5$ billion in 1975 and $\$ 7.0$ billion in the first half of 1976 , as compared with $\$ 10.7$ billion in 1974 (World Bank, Borrowing in International Capital Markets, EC-181/762).

In addition to private source credits, commitments received by developing countries from official sources rose in 1974 (see Table I). Commitments from official sources in 1974 were $\$ 17.84$ billion, an increase of $\$ 4.11$ billion from 1973, of which $\$ 2.44$ billion was from governments and $\$ 1.67$ billion from international organizations. Member countries of the Development Assistance Committee (DAC) of the Organization for Economic Cooperation and Development (OECD) provided two thirds of all commitments from governments in 1974 ( $\$ 7.16$ billion). This was about the same level as in 1973, as an increase in DAC concessional lending was offset by a decline in other credits. Commitments from OPEC governments totaled $\$ 1.93$ billion in 1974 as compared with $\$ 0.19$ billion in 1973. An estimated $\$ 1.29$ billion was concessional. The remaining commitments from governments came largely from centrally planned economies. The increase in commitments from international organizations was divided in roughly equal parts between the World Bank and regional development banks, particularly the Inter-American Development Bank and the Asian Development Bank.

Table 2

Borrowing from financial instifutions by the public sector of 86 developing countries, 1972-74 (In biltions of U.S. dollars)

\begin{tabular}{|c|c|c|c|c|c|}
\hline & \multicolumn{3}{|c|}{ Commitments } & \multicolumn{2}{|c|}{$\begin{array}{c}\text { Debt outstanding } \\
\text { Dec. } 31,1974\end{array}$} \\
\hline & 1972 & 1973 & 1974 & $\begin{array}{l}\text { Undisbursed } \\
\text { only }\end{array}$ & $\begin{array}{l}\text { Including } \\
\text { undisbursed }\end{array}$ \\
\hline \multicolumn{6}{|l|}{ Latin America and } \\
\hline \multicolumn{6}{|l|}{ Of which: } \\
\hline \multicolumn{6}{|l|}{ Major Latin American } \\
\hline Argentina & 0.51 & 0.29 & 0.77 & 1.28 & 1.79 \\
\hline Brazil & 0.98 & 1.35 & 2.22 & 4.65 & 5.08 \\
\hline Chile & 0.07 & 0.14 & 0.01 & 0.77 & 0.86 \\
\hline Colombia & 0.09 & 0.24 & 0.05 & 0.32 & 0.35 \\
\hline Mexico & 0.79 & 2.19 & 2.33 & 5.68 & 6.22 \\
\hline Peru & 0.21 & 0.58 & 0.52 & 0.99 & 1.22 \\
\hline Venezuela & 0.30 & 0.07 & 0.07 & 0.54 & 0.55 \\
\hline Subtotal & 2.95 & 4.85 & 5.97 & 14.24 & 16.06 \\
\hline CACM countries 1 & 0.11 & 0.17 & 0.28 & 0.42 & 0.50 \\
\hline Jamaica & 0.07 & 0.12 & 0.14 & 0.31 & 0.35 \\
\hline Panama & 0.08 & 0.19 & 0.10 & 0.31 & 0.36 \\
\hline \multicolumn{6}{|l|}{$\begin{array}{l}\text { More advanced } \\
\text { Mediterranean }\end{array}$} \\
\hline Of which: & 1.05 & 1.35 & 2.65 & 6.11 & $\mathbf{7 . 3 8}$ \\
\hline Greece & 0.42 & 0.47 & 0.47 & 1.42 & 1.87 \\
\hline Israel & 0.38 & 0.72 & 0.69 & 2.86 & 2.97 \\
\hline Portugal & $\ldots{ }^{2}$ & 0.01 & 0.16 & 0.12 & 0.26 \\
\hline Spain & 0.11 & 0.11 & 0.92 & 1.21 & 1.48 \\
\hline Yugoslavia & 0.14 & 0.02 & 0.37 & 0.41 & 0.68 \\
\hline East Asia and Pacific & 0.70 & 0.88 & 2.46 & 2.12 & 4.47 \\
\hline \multicolumn{6}{|l|}{ Of which: } \\
\hline China (Rep. of) & 0.05 & 0.13 & 0.56 & 0.17 & 0.80 \\
\hline Indonesia & 0.31 & 0.42 & 0.07 & 0.45 & 0.65 \\
\hline Korea & 0.08 & 0.25 & 0.76 & 0.67 & 1.32 \\
\hline Malaysia & 0.11 & 0.03 & 0.75 & 0.37 & 1.05 \\
\hline Philippines & 0.06 & 0.02 & 0.27 & 0.31 & 0.44 \\
\hline \multicolumn{6}{|l|}{$\begin{array}{l}\text { North Africa and Middle } \\
\text { East }\end{array}$} \\
\hline Of which: & 0.85 & 2.23 & 0.87 & 2.60 & 3.84 \\
\hline Algeria & 0.33 & 1.61 & 0.46 & 1.32 & 2.22 \\
\hline Egypt & 0.10 & 0.03 & 0.21 & 0.27 & 0.35 \\
\hline Morocco & $\ldots{ }^{2}$ & 0.01 & 0.11 & 0.11 & 0.20 \\
\hline Iran & 0.39 & 0.54 & 0.05 & 0.77 & 0.88 \\
\hline Tunisia & 0.03 & 0.02 & 0.01 & 0.12 & 0.15 \\
\hline Africa, south of Sahara & 0.35 & 1.19 & 1.06 & 1.81 & 2.97 \\
\hline \multicolumn{6}{|l|}{ Of which: } \\
\hline Ivory Coast & 0.06 & 0.13 & 0.13 & 0.21 & 0.37 \\
\hline Sudan & 0.02 & 0.05 & 0.26 & 0.08 & 0.34 \\
\hline Zaire & 0.12 & 0.57 & 0.52 & 0.67 & 1.29 \\
\hline Zambia & 0.05 & 0.15 & $\ldots 2$ & 0.24 & 0.24 \\
\hline $\begin{array}{l}\text { South Asia } \\
\text { Totals: }\end{array}$ & $\cdots^{2}$ & 0.03 & 0.08 & 0.15 & 0.18 \\
\hline \multicolumn{6}{|l|}{$\begin{array}{l}\text { Totals: } \\
33 \text { selected }\end{array}$} \\
\hline countries & $\mathbf{5 . 9 7}$ & 10.61 & 13.26 & 27.06 & 34.83 \\
\hline 86 developing & & & & & \\
\hline countries & 6.43 & 11.19 & 13.90 & 28.65 & 36.86 \\
\hline
\end{tabular}

Of the $\$ 2.44$ billion increase in commitments from all governments, \$1.1 billion was to South Asia, with more than half the increase going to Pakistan, a substantial portion of which comprised credits from OPEC countries. Credits to a number of North African and Middle Eastern countries grew in 1974. Borrowing by Egypt and the Syrian Arab Republic increased by $\$ 0.3$ billion; Afghanistan 
received $\$ 0.4$ billion from the Soviet Iran (two oil exporting developing countries which had substantially reduced their previous, large levels of borrowing), loans from governments to the North African and Middle Eastern countries increased by $\$ 1$ billion. Commitments from governUnion. Excluding loans to Algeria and

20 per cent, and 45 per cent, respectively.

The growth in borrowing from private financial institutions by middle-income and higher-income group developing countries has affected the timing of their future debt service obligations. This may be seen in the changes of time profile ratios. Compared with borrowing from

Table 3

Debt service time profile ratios for developing countries, 1969 and 1974

\begin{tabular}{|c|c|c|c|c|}
\hline & \multicolumn{2}{|c|}{1969} & \multicolumn{2}{|c|}{1974} \\
\hline & 5 -yr ratio & 10-yr ratio & 5-year ratio & 10-yr ratio \\
\hline 86 developing countries & 48 & 84 & 52 & 90 \\
\hline Loans from governments & 39 & 71 & 38 & 71 \\
\hline Loans from international organizations & 38 & 75 & 31 & 69 \\
\hline Loans from private sources & 75 & 106 & 79 & 124 \\
\hline \multicolumn{5}{|l|}{ Selected regions } \\
\hline (A) Latin America and Caribbean & 58 & 91 & 67 & 85 \\
\hline $\begin{array}{l}\text { Loans from governments } \\
\text { Loans from international }\end{array}$ & 43 & 72 & 50 & 85 \\
\hline organizations & 45 & 91 & 43 & 90 \\
\hline Loans from private sources & 82 & 109 & 85 & 132 \\
\hline (B) South Asia & 34 & 63 & 30 & 55 \\
\hline Loans from governments & 30 & 61 & 31 & 60 \\
\hline Loans from international & . & & & \\
\hline organizations & 26 & 50 & 16 & 31 \\
\hline Loans from private sources & 78 & 116 & 78 & 106 \\
\hline
\end{tabular}

Note: The time profile ratios are calculated by dividing the debt service payments for five years and ten years, respectively, by the debt outstanding at the end of the year indicated. The ratios
shown here are based on the figures published in the statistical annex of the World Bank, Annual Reports for 1971 and 1976.

ments to Latin America, the advanced Mediterranean countries, and the East Asian countries expanded by about $\$ 1.5$ billion in 1974. These consisted mainly of increases in official export credits rather than concessional lending.

\section{Time profile ratios}

The growth in the relative importance of private sector lending to developing countries has affected the structure of developing countries' external debt. At the end of 1974, credits to financial institutions comprised 27 per cent of disbursed debt, compared with 15 per cent only four years earlier. The share of loans from governments fell from 53 per cent to 46 per cent of the total during this period, offset slightly by a relatively faster growth of lending by international organizations. The debt structure of developing countries varies markedly by income group (see footnote 1 to Table 1 for a definition of these groups). At the end of 1974, for the lower-income countries, 65 per cent of external debt consisted of loans from governments, 24 per cent from international organizations, and 11 per cent from private sources. For the higherincome and middle-income non-oil countries, these proportions were 35 per cent, ratio from 106 to 124 . This indicates a hardening of the terms of borrowing, mainly because of the increased level of market interest rates from the late 1960s to the early 1970s. It is also a reflection of the shift in private source financing from suppliers' credits to bank lending; suppliers' credits generally have lower interest rates than bank loans.

The time profile ratio for total debt depends on the terms and relative importance of debt to foreign governments and to multilateral agencies as well as to financial institutions. Between 1969 and 1974, the terms of lending from multilateral agencies as a group softened, reflecting the growing importance of the World Bank lending of International Development Association funds. The five-year time profile ratio for all developing countries fell from 38 to 31 and the ten-year ratio from 75 to 69 . For loans from governments, the time profile ratio has remained practically unchanged despite the better terms for concessional lending, because the growth in the volume of these loans has been more rapid in the form of official export credits than by way of concessional capital. The relative growth in private source borrowing has brought about a net increase in the time profile ratios for those developing countries which have borrowed heavily from private sources. The time profile ratios for all categories of debt combined have increased for Latin American and the advanced Mediterranean countries, reflecting a shortening of the debt maturity structure and a higher interest rate. The ratios for South Asian countries have fallen, accentuating the contrast between countries whose borrowing was largely limited to available concessional finance and those countries which were in a position to attract and service credits from private financial institutions.

\section{Debt management}

The growing dependence upon private financial institutions by the relatively advanced developing countries puts more stress on their debt management capabilities. One factor consists of the effects of shorter maturities. Loans from private banks are typically for terms of five to seven years. Developing countries cannot be expected to become capital exporters by the time amortization on such loans falls due; they will still require net capital inflows and thus the need to roll over principal payments when they fall due.

A second factor is that loans from private financial institutions now have, in large part, variable interest rates. This has 
come about in recent years because of the unprecedented rates of inflation in the world economy and the rapid rise and fluctuation of the interest rates which these institutions pay for deposits. Although this practice introduces greater uncertainties, it can have potential advantages to borrowers as well. The reference rate may rise, as it did in 1973-74, but when it declines, as it did in 1974-76, the reduction in the cost of money is passed along to the borrower. This would not have been the case if the borrowing had been at a fixed rate. The funds which have been lent to developing countries in recent years have come, to a large extent, from institutions receiving Eurocurrency deposits. The lending rate has been based on the rate paid on these deposits plus a margin. The most common base rate for international lending by private financial institutions is the six-month London interbank offer rate (LIBOR), and the margin has varied from as low as $1 / 2$ per cent to more than 2 per cent. The three-month and one-year LIBOR have also been used as bases. Banks lending from domestic deposits often base their rates on a domestic reference rate. For example, U.S. banks might fix their rates in relation to a U.S. "prime rate." Interest charges are normally adjusted at six-month intervals.

At the end of 1974, half of the debt outstanding of all 86 developing countries to private financial lending institutions consisted of variable interest rate debt; but, for the regions highly dependent on financial credits, nearly two thirds consisted of variable interest rate debt. Greece, for example, received $\$ 0.5$ billion of credits from financial institutions in 1973 and 1974 (public sector borrowing as recorded in the Debtor Reporting System), of which 90 per cent consisted of variable interest rate loans as contrasted with only 46 per cent during the period 1970-72. The proportion of debt to financial institutions which consists of variable interest rate loans has risen.

This problem can be elucidated by describing the fluctuations of the LIBOR during the past five years. The six-month LIBOR, for example, fluctuated between $51 / 4$ per cent and $61 / 4$ per cent during 1972 , but in the year 1974 averaged 11.2 per cent and exceeded 14 per cent during August 1974. The rate declined steadily in 1975 , reaching 5.9 per cent in January 1976 and then rose again in the first half of 1976, averaging 7.8 per cent in June. Until recently, when forecasting a country's future balance of payments position, debt service on debt outstanding at the base period has been one of the given ele- ments; the major unknowns are exports and imports and debt service on new borrowings. Now, with the advent of variable interest rate debt, interest on much of the debt to private financial institutions is itself a dependent variable, the level fluctuating with short-term money market conditions. To show the significance of this phenomenon, the projected future interest charges on variable interest debt to private financial institutions outstanding at the end of 1974 were recalculated.

\section{Debt statistics published by the World Bank}

World Debt Tables (EC-167/76). This two-volume statistical compilation is based on reports by developing countries which borrow from the World Bank of public and publicly guaranteed debt with a maturity of more than one year. Figures are included for 86 countries whose data are sufficiently reliable for presentation. EC-167/76, which contains debt figures only through end-1974, is supplemented by bimonthly country data sheets giving summary debt statistics on data for end-1975 as they become available. Borrowing in International Capital Markets (EC-181). This is a compilation of foreign and international bond issues and of Eurocurrency credits, published quarterly. A recently issued supplement lists all bond issues and Eurocurrency credits for the years 1973-75.

One set of estimated future interest charges was calculated using a historically high interest rate (the average six-month LIBOR prevailing during 1974 was used) and another was calculated using a historically low rate (the average six-month LIBOR for 1972). If interest rates were at their historically high level, debt service due to private financial institutions in calendar year 1976 on debt outstanding as of end-1974 would have been $\$ 5.50$ billion. If interest rates were at their historically low level, debt service would have been $\$ 4.66$ billion. Three quarters of this hypothetical swing of $\$ 840$. million would have been concentrated in Latin America and in the more advanced Mediterranean countries, the two regions of the developing world most highly dependent upon credits from financial institutions.

The figures for potential variations in debt service payments for 1976 do not reveal the entire magnitude of the potential swing in debt service during 1976. In the first place, although complete data are not available, it is clear that there has been an increase in credits from financial institutions in 1975 and 1976, and the proportion bearing variable interest rates appears to be higher than in earlier years. Second, the debt service figures cover public sector borrowing only. Much of private sector debt apparently consists of variable interest rate financial credits. If they continue to grow relative to credits at a fixed rate of interest, the amount of interest payments subject to uncertainty will also increase.

The potential swing estimated for debt service payments, even if adjusted upward to take account of recent disbursements and private sector debt, is not large relative to total exports of developing countries. However, a problem may arise in the future for individual countries with a large amount of variable interest rate debt. A rise of interest rates in the industrialized countries used as reference rates would bring about an increase in interest costs.

In conclusion, it may be observed that the ability of developing countries to run substantial balance of payments deficits since 1973 through long-term borrowing has been limited to two groups of countries: those lower-income countries which were in a position to secure additional concessional financing and those countries, largely middle-income and higher-income countries, which were in a position to borrow from suppliers and from financial institutions. The fact that large amounts of funds have been available to developing countries through commercial channels has been a very desirable feature of the international financial system. However, this growth of lending by financial institutions to developing countries imposes responsibilities on borrowers and lenders. For the borrowing countries, skillful and prudent balance of payments management has become a matter of increasing importance. Growing debt service payments in general, combined with the potential swing in interest payments on variable interest rate loans, increases uncertainty, and the growth in the amounts outstanding increases vulnerability to cyclical disturbances. Minimizing balance of payments stresses is important if a developing country wishes to remain creditworthy for lending by private financial institutions. For the lending countries, there must be a recognition that the continuity of the development effort in the developing countries will continue to require refinancing of maturing debt, and that the banking arrangements which made possible the growth of financial credits to developing countries should continue to have the flexibility to make such accommodation possible. 


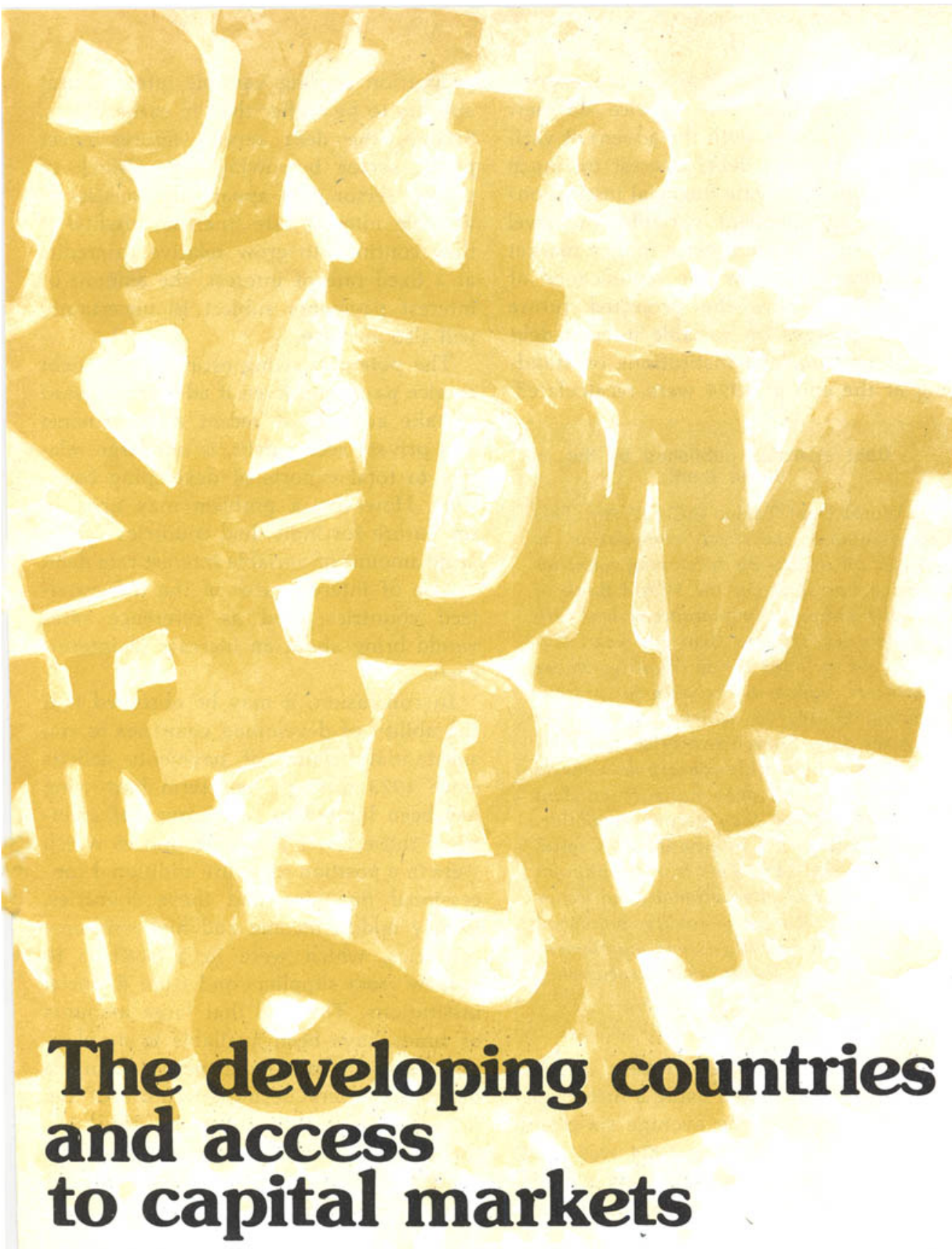

Although developing countries have been able to raise funds from credit markets recently, their borrowing from the major bond markets of the world has been relatively small. The crucial factor has been the market perception of their creditworthiness, but there are regulations and practices which also tend to inhibit their access. This article examines the situation from the point of view of the less developed countries.

\section{M. Ahmad}

In June 1975 the Development Committee of the Bank and the Fund established a Working Group of representatives of 12 members of the Committee, 7 representing capital market countries and 5 representing developing countries. The Working Group was instructed to make a review of regulatory and other constraints affecting the developing countries' access to capital markets, and also to study further proposals to support their access to private

markets, including the use of multilateral guarantees.

The primary areas of interest of the review included (1) restrictions and other obstacles to access to markets; (2) direct measures to support the creditworthiness of developing country borrowers in capital markets, including possible multilateral guarantees or active use of guarantee authority of international lending institutions; (3) the problem of secondary mar- kets for developing country securities; (4) cofinancing involving international lending institutions and private lenders; (5) a possible international investment trust; and (6) technical assistance to developing countries seeking market access, and the related problem of educating potential investors regarding the situation and prospects of developing countries.

The Secretariat of the Development Committee had held consultations with representatives of the Governments of Brazil, Korea, Mexico, and the Philippines, and also with the authorities and the banking communities in Belgium, France, the Federal Republic of Germany, Japan, Luxembourg, the Netherlands; Switzerland, the United Kingdom, and the United States. The results of the survey relating to regulations and practices that are presented in part in this article, were put before the Development Committee at its October 1976 meeting in Manila, and a number of concrete steps to improve developing country access were agreed upon at this meeting.

\section{The credit and bond markets}

It is a well-known fact that the less developed countries (LDCs) have been able to tap the Eurocredit market substantially in the past few years (see Table 1). While recognizing the important and valuable role played by banks during the recent period of pronounced balance of payments difficulties, domestic monetary authorities have increasingly questioned the wisdom of continuous and large-scale commercial bank involvement in straight balance of payments financing. The sizable bank exposure in particular areas coupled with some fears about possible defaults has led authorities to call for a re-examination of bank lending and to refrain from what might be regarded as the excesses of 1973 and early 1974. In fact, in most countries where international banking plays an important role, the domestic authorities have already taken measures to regulate Eurocredit lending.

While concern about bank lending to LDCs as such cannot be justified on the basis of commercial banks' loan/loss experience vis-à-vis the LDCs, which has been good, the Eurocredit markets may not be able in the future to provide LDCs with resources of the same magnitude as in the past few years.

The problem of "crowding out" of LDCs on account of increased loan demand generated by the economic recovery in the industrial countries may not be imminent. It is, however, unlikely that whatever capital continues to be available 
through the credit market will be on terms and maturities generally suitable for development purposes. In fact, in 1975 and 1976, loan maturities have shortened considerably and spreads over the London interbank offer rate (LIBOR) have increased to levels more than twice those applying early in 1974. (Maturities of five to seven years and spreads of 2 per cent
When allowance is made for the substantial borrowings by Israel in the U.S. market, the share of other LDCs in the bond markets comes down to 3.6 per cent in 1973-75 (of which 3.1 per cent was in the foreign bond market and 4.2 per cent in the Eurobond market), and among these, bond issues by Mexico and Brazil have been predominant.
Table 1

Publicized Eurocredits, 1973-75

(In millions of U.S. dollars)

\begin{tabular}{|c|c|c|c|c|c|c|}
\hline & \multicolumn{2}{|c|}{1973} & \multicolumn{2}{|c|}{1974} & \multicolumn{2}{|r|}{1975} \\
\hline & Total & $\begin{array}{c}\text { Share } \\
\text { (Per cent) }\end{array}$ & Total & $\begin{array}{c}\text { Share } \\
\text { (Per cent) }\end{array}$ & Total & $\begin{array}{c}\text { Share } \\
\text { (Per cent) }\end{array}$ \\
\hline Industrial countries & 11,687 & (56) & 17,243 & $(60)$ & 5,090 & (25) \\
\hline Developing countries ${ }^{1}$ & 6,998 & (34) & 7,480 & (26) & 10,892 & (53) \\
\hline Other & 2,179 & (10) & 3,809 & (14) & 4,593 & (22) \\
\hline Total & 20,864 & $(100)$ & 28,532 & $(100)$ & 20,575 & $(100)$ \\
\hline
\end{tabular}

Source: World Bank.

1 Includes oil exporting countries. Excluding them, the figures are $\$ 4.3$ billion (20 per cent) in $1973, \$ 6.7$ billion (23 per cent) in 1974, and $\$ 7.7$ billion (37 per cent) in 1975. Excludes loans

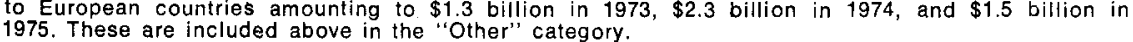

and above are presently typical for loans to LDCs.) In these circumstances, the importance of the bond markets as a stable source of long-term capital for LDCs can hardly be overstressed.

Although LDCs have been able to tap the credit markets successfully, their borrowing in the bond markets has been relatively small. As compared with $\$ 25.4$ billion or 36 per cent of all publicized Eurocredits raised from 1973 to 1975 , LDCs raised only $\$ 2.9$ billion or 6.4 per cent of total bond issues (foreign and Eurobonds) during this period (see Table 2).
This performance has been explained in large part by the fact that in the bond markets LDCs face investors who are generally unfamiliar with them and are, therefore, not willing to take risks as readily as bankers. In addition, larger institutional investors who are in a better position to assess the quality of the borrower, are limited in their investment, by regulations as well as by their traditionally conservative behavior. For the developing countries there has been more incentive to take bank credits than to issue bonds since at present they are generally of similar maturities, although the fact that bonds are fixed interest obligations might appeal to a number of borrowers. In addition, some practices or regulations, particularly in the domestic markets, have had the effect of limiting access to bond markets by foreign borrowers. The LDC share has been relatively small in both the foreign and Eurobond segments of the international capital market where practices and regulations are quite different.

\section{Regulations}

The Eurobond market: Unlike the foreign bond market (see below), the issuing activity in the Eurobond market is relatively unregulated. Some degree of regulation, nevertheless, exists, arising mainly from the reluctance of some countries to permit the use of their currencies as international reserve assets. Thus, the Swiss and the Dutch authorities do not encourage Euroissues denominated in their currencies. The authorities of the Federal Republic of Germany do permit the use of the deutsche mark (DM) in international bonds, but require that such issues should be treated like any, other deutsche mark issues and thus Euro-DM issues are in practice governed by the queue system operated by the Capital Markets Committee. The Eurodollar issues are the freest of all. Like the domestic and foreign dollar issues in the U.S. market, they do not require any authorization, and unless they are publicly offered in the United States, Securities and Exchange Commission (SEC) registration is also avoided.

It is not surprising, therefore, that the

Table 2

International bond issues, 1973-75

(In millions of U.S. dollars or equivalent)

\begin{tabular}{|c|c|c|c|c|c|c|c|c|c|}
\hline & \multicolumn{3}{|c|}{1973} & \multicolumn{3}{|c|}{1974} & \multicolumn{3}{|c|}{1975} \\
\hline & \multirow[t]{2}{*}{ Total } & \multicolumn{2}{|c|}{ LDC share ${ }^{1}$} & \multirow[t]{2}{*}{ Total } & \multicolumn{2}{|c|}{ LDC share ${ }^{1}$} & \multirow[t]{2}{*}{ Total } & \multicolumn{2}{|c|}{ LDC share ${ }^{1}$} \\
\hline & & Total & Per cent & & Total & Per cent & & Tótal & Per cent \\
\hline Eurobonds & 4,600 & 439 & $(9.5)$ & 4,515 & 96 & $(2.1)$ & 10,199 & 271 & (2.7) \\
\hline Public issues & 3,179 & 199 & (6.3) & 1,559 & 92 & $(5.9)$ & 6,753 & 183 & $(2.7)$ \\
\hline Private placements & 1,421 & 240 & (16.9) & 2,956 & 4 & $(0.1)$ & 3,446 & 88 & (2.6) \\
\hline Foreign bonds ${ }^{2}$ & 5,314 & 750 & $(14.1)$ & 7,786 & 741 & (9.5) & 11,913 & 561 & (4.7) \\
\hline Public issues & 2,973 & 544 & (18.3) & 2,526 & 276 & $(10.9)$ & 7,374 & 318 & $(4.3)$ \\
\hline Private placements & 2,341 & 206 & $(8.8)$ & 5,260 & 465 & $(8.8)$ & 4,539 & 243 & $(5.4)$ \\
\hline Total & 9,914 & 1,189 & $(12.0)$ & 12,301 & 837 & $(6.8)$ & 22,112 & 832 & (3.8) \\
\hline Public issues & 6,152 & 743 & (12.1) & 4,085 & 368 & $(9.0)$ & 14,127 & 501 & (3.5) \\
\hline Private placements & 3,762 & 446 & $(11.9)$ & 8,216 & 469 & $(5.7)$ & 7,985 & 331 & $(4.1)$ \\
\hline
\end{tabular}

Source: World Bank.

1 Includes issues by oil exporting countries amounting to $\$ 226$ million during $1973-75$ but excludes issues by European countries amounting to $\$ 450$ million during the same period.

2A substantial portion of the foreign bond issues have been by Israel, amounting to $\$ 468$ million in 1973 , $\$ 560 \mathrm{million}$ in 1974 , and $\$ 243$ million in 2A substantial portion of the foreign bond issues have been by Israel, amounting to $\$ 468$ million in 1973 , $\$ 560$ million in 1974 , and $\$ 243$
1975. If these were excluded, the LDC share in the total comes down to 5.3 per cent in $1973,2.3$ per cent in 1974 , and 2.7 per cent in 1975 . 
large bulk of the Euroissues is denominated in dollars. The next in importance is the deutsche mark. Given the large investor demand for strong currencies like the deutsche mark, its share in Euroissues could possibly have been larger if Euro-DM issues could be made as freely as dollar issues. More generally, the prospects for LDC borrowing in the Eurobond market would improve if the authorities would take a more liberal view of bonds denominated in their currencies and issued by LDC borrowers.
Bankers who manage and underwrite Eurobond issues feel a "moral" obligation toward unsophisticated individual investors and are not willing to admit issues of unfamiliar borrowers or those whose creditworthiness has not been established. The authorities also seem to take a similar view when they permit individuals to purchase Eurobonds but do not permit active marketing, especially when the issues have not gone through their own clearance procedures. Quite a few of the Eurobond issues by developing

\section{"a continuing relationship with developing countries is an important factor in generating familiarity and trust"}

Regulations also apply to the purchase by resident investors of Eurobonds. Individuals are generally free to purchase foreign bonds and Eurobonds in most countries. Restraints, when imposed, are for balance of payments reasons. There are also conditions imposed as to the type of foreign security which can be freely purchased in an effort to protect the investor. The test applied most generally is that the security must be listed-thus ensuring that some authority somewhere has gone through the motions of examining the prospectus and requiring essential disclosures. Resident institutional investors in some countries cannot, however, acquire securities (domestic or foreign) denominated in foreign currencies, except to the extent that they have liabilities to match in those currencies.

These rules do not seem to have a restraining influence in the Eurobond market, although they contribute to the "retail" character of the market in which individual investors predominate. One consequence of this, for LDC borrowers is that creditworthiness considerations, important in other markets, carry even more weight in the Eurobond market. The quality of the issue is of prime importance, and even developed country entities-especially public sector corporations-find it difficult to establish themselves in such a competitive market. There is little systematic information on the pattern of Eurobond holdings, and the banking community seems to have developed a conspiracy of silence on the subject. This may be a reflection of the fact that Eurobonds-m-wich are invariably in the form of bearer bonds-are used as safe tax havens by wealthy individuals from all over the world. (It is recognized, for instance, that nearly half of all Eurobonds end up in Switzerland.) country borrowers have been essentially Eurocurrency credits dressed up as bonds. They have virtually remained on the books of the banks.

The foreign bond market: It is useful to distinguish between the U.S. market of foreign bonds and other markets. In the U.S. market, where formal permission for an issue is not required, the main problems seem to be the registration requirements of the SEC and limitations on institutional investors. Compliance with SEC requirements is generally regarded as difficult, especially for corporate borrowers, and tends to be costly. While, in the aggregate, institutional investors in the United States have room for increased investments in foreign bonds, there may be particular cases where such limits have already been reached.

In the European and the Japanese markets, on the other hand, the main problem seems to be the authorization for foreign issues and/or the existence of issue calen-

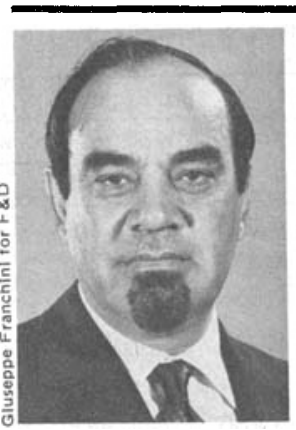

M.M. Ahmad from Government College, Lahore, Pakistan, and a B.A. from London University, England. A former civil servant of Cabinet rank in the Government of Pakistan, Mr. Ahmad was an Executive Director of the Bank from July 1972 to October 1974. He was the acting Executive Secretary of the Development Committee from April to October 1976. dars or ceilings. Some governments with large borrowing requirements of their own or their public sector agencies, seek to prevent competing foreign issues altogether and have strict regulation of competing domestic private issues. Others maintain a regulatory system, but are either more willing or more able to accommodate nongovernment issues, including foreign issues. In almost all cases, developing country issues, although not formally discriminated against, tend to have a poor chance of admission. The queues are not always on a first-come-first-served basis; nor are the criteria for priority in the queue well defined or made known. In some cases, the "queue" is more like a "crowd," from which the underwriters, with explicit or implicit government blessing, pick the best potential winners in the market.

Restraints are placed on foreign access in both the Eurobond market and the foreign bond market, but they are considerably greater in the latter. In either case, they are nondiscriminatory. Yet, bond issues by developed country borrowers have been sizable, while the share of developing countries has been small in both the foreign bond market and the relatively unregulated Eurobond market. It would seem, therefore, that the more crucial limitation to developing country access is lack of familiarity on the part of investors of conditions in developing countries, and, more generally, creditworthiness and the market perception of the creditworthiness of these countries.

The banking community in several countries has expressed the view that a continuing relationship with developing countries is an important factor in generating familiarity and trust. They point to the fact that developing countries have had success in raising finance through bank loans. When it comes to the bond market, however, one is dealing with a large number of individual and institutional investors who are concerned primarily with purchases of "good quality" paper. Individuals tend to be unsophisticated investors and are unlikely to be interested in bonds about which there is the slightest doubt. Institutions such as insurance companies might be expected to be more sophisticated about their portfolio structure and might be able to assess risks and be prepared to purchase slightly riskier bonds if the yield is commensurate. They would be more willing to do so especially in respect of bonds of countries where they happen to have a business relationship. To some extent, a further development of their interest in such 


\section{The Development Committee}

The Development Committee, formally known as the Joint Ministerial Committee of the Boards of Governors of the Bank and the Fund on the Transfer of Real Resources to Developing Countries, emerged as a result of two major factors. First, the Committee of Twenty (set up to study the reform of the international monetary system and related issues), in its Outline of Reform in June 1974 suggested the formation of a committee to continue the study' of the broad question of the transfer of real resources to developing countries. Second, the developments in the world economic situation during 1973 and 1974, which left most of the developing countries facing serious difficulties such as trade and current account deficits, created the need for a flow of financial resources of a concessional nature to these adversely affected countries.

Parallel resolutions of the Boards of Governors of the Bank and the Fund established the Committee on October 2, 1974 under the following terms of reference:

(a) The Development Committee shall maintain an overview of the development process and shall advise and report to the Boards of Governors of the Bank and the Fund on all aspects of the broad question of the transfer of real resources to developing countries, and shall make suggestions for consideration by those concerned regarding the implementation of its conclusions. The Committee shall review, on a continuing basis, the progress made in fulfillment of its suggestions.

(b) The Development Committee shall establish a detailed program of work, taking account of the topics listed in Annex 10 of the Outline of Reform. The Committee in carrying out its work shall bear in mind the need for coordination with other international bodies. (c) The Development Committee shall give urgent attention to the problems of (i) the least developed countries and (ii) those developing countries most seriously affected by balance of payments difficulties in the current situation.

The members of the Development Committee are governors of the Bank, governors of the Fund, ministers, or others of comparable rank.

At the inaugural meeting of the Committee, held October 2-3, 1974, Mr. Henri Konan Bédié, Minister of Economy and Finance of Ivory Coast, was selected as Chairman, and Mr. Henry J. Costanzo, Executive Vice President of the Inter-American Development Bank, was appointed Executive Secretary. Mr. Costanzo resigned effective April 15, 1976, and on that date, Mr. M.M. Ahmad, Deputy Executive Secretary, assumed duties as Acting Executive Secretary.

At its seventh meeting in Manila on October 6, 1976, the Committee selected Mr. Cesar E. A. Virata, Secretary of Finance of the Philippines, as Chairman, and appointed Sir Richard King, K.C.B., M.C., Permanent Secretary of the Ministry of Overseas Development of the United Kingdom, as Executive Secretary.

Over the long term, the Committee aims to focus on the long-range real resource requirements of all developing countries, with particular reference to the poorest income group, in order to assist these countries to achieve and maintain reasonable growth rates during the balance of this decade.

Other long-term subjects which have been under review are broadly (1) the amount and quality of official development assistance; (2) programs and resources of multilateral development finance institutions; (3) improvement of access to capital markets; and (4) international financing schemes for commodity regulation and price stabilization. bonds tends to be constrained by the existence of regulations which put ceilings on their foreign investments.

In sum, a relaxation of regulations per se may not result in any substantial improvement in the prospects for developing countries-especially for those developing countries which have no established record. But, if other measures are taken at potential for substantial increase in their borrowing could be created which will not be realized unless some of the existing restrictions on access of nonresident issues are relaxed. Such relaxation will, in any case, be of considerable help to those developing countries which have an established record of creditworthiness in some markets but are unable to diversify their borrowing by approaching other markets.

\section{Modifying the regulations}

Three approaches to the modification of the existing regulations and practices may be explored:

- General liberalization of capital outflows to developed as well as developing country borrowers, ending progressively the existing discrimination against nonresident borrowers;

- agreement to grant preferential treatment to developing country borrowers; - agreement that capital market countries would take such specific actions as may be appropriate to their situations to improve the access of developing countries to their markets.

General liberalization: The main rationale of the present regulations is threefold: balance of payments considerations (countries facing a deficit might seek to prevent a capital outflow; but those in a surplus situation might seek to prevent an "excessive" appreciation of their currency by regulating the creation of instruments denominated in their currency); domestic capital needs; and protection of the investor.

A general liberalization does not appear feasible so long as large disequilibria in balance of payments persist. It is arguable that other methods to correct these disequilibria could be employed, including domestic, fiscal, and monetary policies as well as greater flexibility in exchange rates, rather than imposing regulations on capital movements. But at the present stage of debate on these questions, it is unrealistic to expect a general move toward liberalization of capital movements. The efforts of the Organization for Economic Cooperation and Development (OECD) in that direction may be noted in this context, and to the extent they succeed there will be indirect benefits for developing countries.

Nonresident borrowing will invariably compete with domestic needs of capital; and the unwillingness of governments to compete freely for their own requirements arises primarily from their desire to keep their own costs of borrowing as low as possible. It is unlikely that governments 
would consider greater freedom for capital movements if this reduces their freedom to set interest rates at levels considered desirable for achieving the objectives of domestic economic policy. Also, so long as domestic private borrowers are subject to authorization and queue procedures, it would be politically difficult to extend a generally favorable treatment to foreign borrowers.

Preferential treatment: None of the countries studied discriminate against developing country borrowers. The regulations are applied uniformly to all foreign borrowers, although, in practice, developing countries tend to be at a disadvantage in a restricted market. Discrimination between a developing country borrower and a domestic borrower could be politically difficult-for instance, when the market is closed to all issues, including domestic issues, it may be difficult to permit a foreign issue: Discrimination among foreign borrowers in favor of developing countries looks more feasible politically, but may not yield more than marginal benefits so long as the degree of restriction on nonresident borrowing remains severe. A general agreement to grant preferential treatment to developing countries can be of greater benefit if it is accompanied by (1) willingness to discriminate against domestic borrowers as well in certain situations and/or (2) a willingness to reduce the severity of restrictions as applied to nonresident borrowers generally to permit greater room for developing countries.

Specific actions: Under this approach, the content of the actions to be taken could be determined by each capital market country in the light of its own situation, but there would be an understanding that each country would take action to improve the access of developing country borrowers to its market.

At the Development Committee meeting in Manila it was agreed that governments of capital market countries would afford favorable treatment, among foreign borrowers, to developing country borrowers in their markets with regard to: (1) permission to make bond issues; (2) a place in the issue calendars; (3) quantitative limitations on foreign bond issues in their markets; and (4) denomination of Eurobond issues in currencies which are in strong demand. The Committee also urged capital market countries to give earnest consideration to a number of recommendations concerning the removal of legal and administrative barriers so far as was consistent with investors's protection.

A1

\section{The Trust Fund}

This article describes a new form of assistance to developing countries facing balance of payments difficulties. Financed by profits from the sale of one sixth of the gold held by the IMF, which has already begun, and any voluntary grants, loans, or investment income received by it, the Trust Fund is expected to start making disbursements in January 1977.

\section{Ernest Sturc}

In the aftermath of the sharp increase in oil and other prices, it was generally recognized that the low-income developing countries would be the most seriously affected and that special steps needed to be taken at the international level to assist them in financing their essential import requirements. One such step was the United Nations Emergency Operation which was set up in 1974 to render emergency assistance for one year; it has now been succeeded by a UN Special Fund which is designed to provide aid to the most seriously affected and other lowincome countries. At the IMF an oil facility was created in 1974 to meet a part of the increased cost of importing petroleum. The facility was continued in 1975 and a Subsidy Account was established to afford interest relief on drawings from the $\mathbf{1 9 7 5}$ facility by the most seriously affected developing countries. The UN Emergency Operation has allocated US\$263 million in grants, while the two IMF oil facilities have provided SDR 2.5 billion (the equivalent of approximately US\$3 billion) in loans to developing countries.

In view of the continuing pressing needs of the low-income developing countries, the Joint Ministerial Committee of the Boards of Governors of the Bank and the Fund on the Transfer of Real Resources to Developing Countries (the Development Committee), after meeting in Washington in January 1975, invited the Executive Directors of the Bank and the Fund to study the desirability of cre- ating a Special Trust Fund to provide highly concessional resources to help meet the balance of payments needs of such countries in the period immediately ahead.

In their report to the Development Committee, the Executive Directors recognized that, even with greater effort on the part of the low-income developing countries to mobilize domestic resources and to expand their exports, their balance of payments positions would remain under severe strain for several years beyond 1975. They therefore agreed that there was a need to make additional financial resources available to these countries on appropriate terms. They recommended that, if resources additional to those currently available to developing countries through other channels could be obtained, consideration should be given to establishing a Special Trust Fund, to be administered by the IMF, to render highly concessional balance of payments assistance. However, it was noted that there was great uncertainty as to whether sufficient financial support could be expected. One of the suggestions made was to use, directly or indirectly, some of the gold holdings of the Fund. After considering this report, the Development Committee agreed to urge the Executive Directors of the IMF to consider all aspects of the establishment of such a Trust Fund, as well as to continue their study of all possible sources of financing.

The next major advance toward the creation of a Trust Fund came in August 
1975 when the Interim Committee of the Fund's Board of Governors decided, as part of the agreement on the role of gold in the future international monetary system, that the profits from the sale of one sixth of the 'IMF's gold holdings (25 million ounces) should be used for the benefit of developing countries. Meeting shortly thereafter, the Development Committee agreed in principle that the profits from these gold sales should be used to establish a Trust Fund. At the meetings of the Interim Committee and the Development Committee held in Jamaica in January 1976, an understanding was reached to ask the Executive Directors of the Fund to establish without delay a Trust Fund financed by profits from these gold sales, to be augmented by voluntary national contributions.

It was agreed that the gold should be sold over a four-year period and that, initially, member countries with per capita incomes in 1973 of less than SDR 300 would be eligible. The operational details were worked out over the next few months, the decision to establish the Trust Fund was taken by the Executive Directors on May 5, 1976, and the first of the 16 gold auctions planned over the first two-year period was conducted on June 2 . Although the profits actually realized will depend on market developments as the gold is auctioned at intervals of about six weeks, it has been estimated that these profits might approximate US\$500 million a year.

The operations of the Trust Fund will be divided into two distinct two-year periods beginning July 1, 1976 and July 1, 1978. The amounts available for disbursement by the Trust Fund during each period will include the profits from one half of the total gold to be sold, as well as any voluntary national grants or loans and any investment income received by the Trust Fund during that period. These resources available for lending during each period will be allocated to eligible members in proportion to their Fund quotas on December 31, 1975. Although the total resources available for lending will not be known until the end of each period, regular interim disbursements will be made in order to provide timely assistance, with the first disbursement expected around January 1977.

\section{Eligible recipients of aid}

Sixty-one low-income countries are included in the initial list of eligible members. The Executive Directors will review this list and the criteria for eligibility before the beginning of 1978. If all 61 countries were to qualify for assistance, India, with the largest quota, would be entitled to borrow 25 per cent of the Trust Fund's resources, to be followed by Indionesia, Pakistan, and Egypt, with entitlements to borrow 6.9,6.3, and 5.0 per cent of the Trust Fund's resources, respectively.

In order to qualify, an eligible member must establish that, for a 12-month period, it has a need for balance of payments assistance and is making a "reasonable" effort to strengthen its balance of payments position. For assistance during the first phase of the Trust Fund's operations, the relevant 12 -month period must begin between January 1, 1976 and December 1, 1977. The need of a member will be assessed on the basis of the member's balance of payments position, its reserve position, and developments in its reserves. In determining a reasonable effort, the IMF will adopt the same criteria as are applied to purchases in the first credit tranche.

If a member has submitted a 12-month program in connection with a use of Fund resources in the credit tranches or under the extended Fund facility, that program will qualify as the basis for Trust Fund assistance. Other members may qualify by submitting a program which would meet the criteria of reasonable effort, and, as in the case of first tranche purchases, discussions on the program will normally include a staff visit to the member country. The calculated need for assistance may be cumulated over more than one 12-month program during each phase of the Trust Fund's operations. Once the final list of qualifying eligible members has been

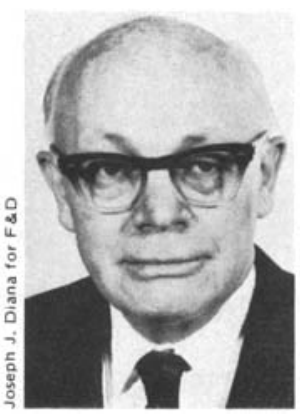

Ernest Sturc

Relations Department. He is a graduate of the University of Bratislava, Czechoslovakia, and the University of Chicago, U.S.A. He was a member of the Czechoslovak delegation to the Bretton Woods Monetary Conference in 1944 and the San Francisco Conference on the establishment of the United Nations in 1945. established, the funds available during each two-year phase of the Trust Fund's operations will be allocated on the basis of the proportional quotas described above.

Although the criteria and mechanism for allocating Trust Fund loans have been established, the actual amount of money available for lending will not be known until near the end of each two-year period. During each period, 12.5 million ounces of gold will be sold. However, until the current Articles of Agreement are amended, the Fund itself can only sell gold to member governments to replenish its supply of currencies needed in its operations, and it can only sell that gold at the official price under the Articles of SDR 35 a fine ounce. To facilitate the establishment of the Trust Fund before the second amendment of the Articles is approved, agreement has been reached whereby the IMF will sell gold to major central banks at SDR 35 a fine ounce and those banks, in turn, will sell the gold to the Trust Fund at that official price. The Trust Fund, a separate legal entity from the IMF, can then sell the gold in public auctions.

It is hoped that, in addition to these profits from the gold sales, the Trust Fund will also receive a number of voluntary contributions from member governments. While no formal commitments have yet been received, spokesmen from some countries have indicated that such contributions might be forthcoming. It is also hoped that regional and other funds might consider loans or contributions to the Trust Fund as an effective way to provide assistance to the most needy developing countries.

The value of loans granted by the Trust Fund will be expressed in terms of SDRs. The loans will carry an interest charge of $1 / 2$ of 1 per cent per annum and, after a grace period of five years, will be repayable in equal semiannual installments terminating with a final payment ten years after the initial disbursement. These installments may be rescheduled if the IMF finds that repayment on the due date would result in serious hardship for the member.

Before January 1, 1978, the IMF will review the Instrument establishing the Trust Fund and may, at that time, modify the list of eligible countries, the need and reasonable effort criteria for assistance, and the terms and conditions governing loans from the Trust Fund. The IMF may decide that any modification which is favorable to eligible members will apply retroactively. 


\section{Fluctuating exchange rates}

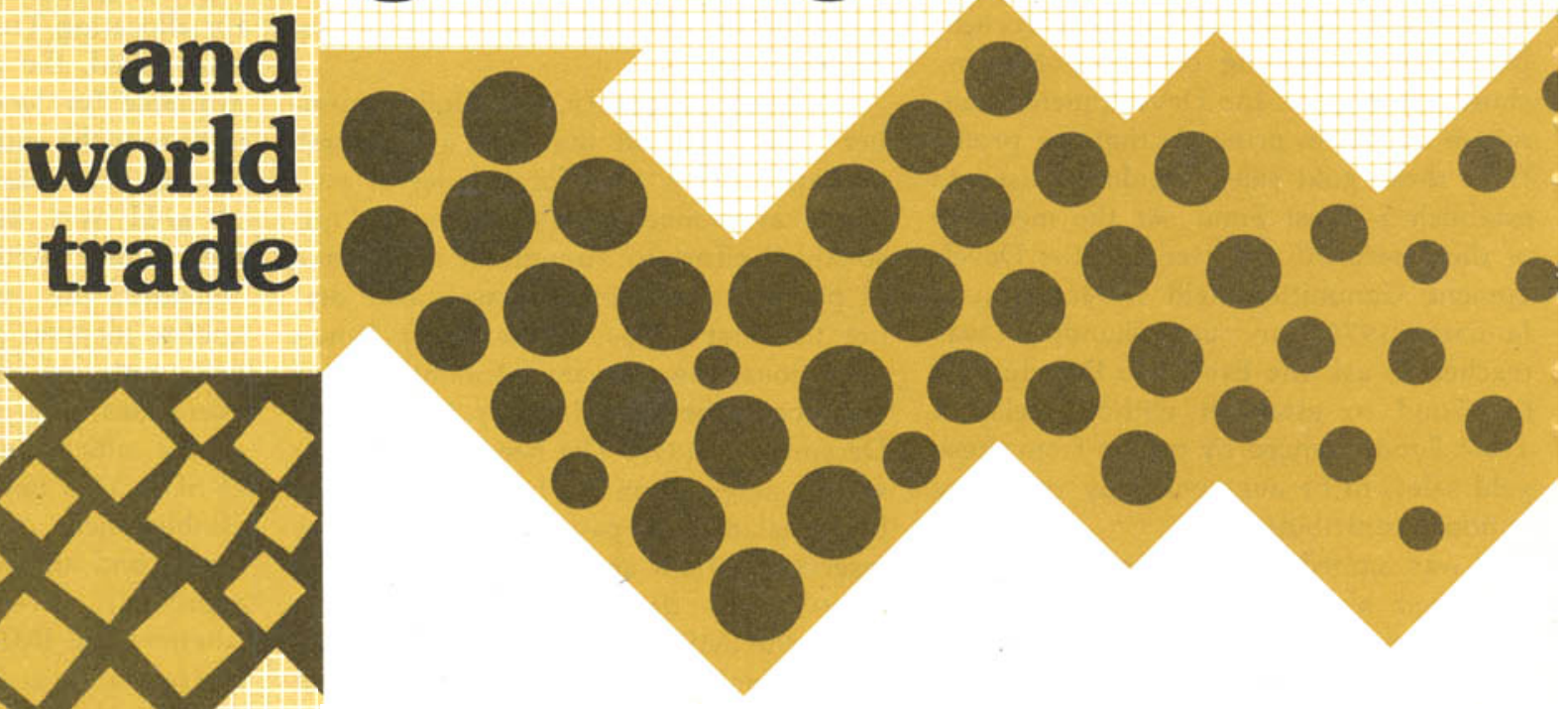

Rules governing international trade and monetary affairs have an important effect on each other, yet reforms in these areas have been-and are being-conducted separately. This article examines some implications of fluctuating exchange rates for international trade and vice versa.

Bahram Nowzad The mid-1970s have been characterized by efforts to re-examine the rules, procedures, and arrangements that govern trade and payments among nations. In the wake of the breakdown of the Bretton Woods fixed exchange rate system in 1971, the Fund's Committee of Twenty and its successor, the Interim Committee, have had the task of reforming the international monetary system. As regards exchange arrangements, agreement that was reached in Jamaica in January 1976 (see "The Fund after Jamaica" by J. J. Polak, Finance \&

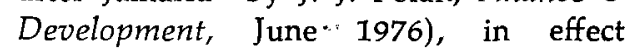
legitimized and formally recognized the exchange practices that had evolved in the intervening period. In the field of trade, a new round of trade talks was launched in September 1973 but negotiations began in earnest only in early 1975 after the passage of the U.S. Trade Act. The new round of trade negotiations are the broadest ever attempted, covering tariffs, nontariff barriers, and agriculture; special attention is to be paid to the problems of developing countries.

That there is a close interrelationship between international trade and international monetary matters is obvious: the rules governing international payments have a crucial bearing on trade, while barriers to trade affect the functioning of the international monetary system. Hence, 
for a liberal and efficient world trade and monetary system, the rules and arrangements in the two spheres must be mutually compatible and supportive. However, the preparations and the negotiations in the two areas have been almost totally isolated from each other with each set of negotiations proceeding in a separate forum, in a different manner, and at a different level. Indeed, a casual observer surveying the negotiations in the two areas might have been forgiven for reaching the conclusion that trade and monetary matters were virtually unrelated (a conclusion he might also have reached from a survey of much of international monetary and trade theory)!

For historical and other reasons negotiations in the monetary and trade spheres differ in many ways: trade negotiations are typically based on the mutual bargaining of concessions on tariffs and other trade barriers among the participants, while monetary negotiations aim at the achievement of a set of rules that will govern monetary relations. Notwithstanding the reasons for separate and uncoordinated negotiations in the two fields, it is interesting to consider in more detail some of the possible implications of exchange arrangements on trade measures and vice versa.

\section{Exchange arrangements}

Of the principal changes that have resulted from the reform of the international monetary system, those relating to exchange arrangements are likely to have the greatest bearing on trade and on the multilateral trade negotiations. The other major changes (such as those relating to the role of gold, use of special drawing rights (SDRs), financial activities, possible establishment of a Council in the Fund and organizational matters) will, if at all, exert an indirect influence on trade and the trade negotiations.

Formally, the agreed exchange arrangements will (1) give Fund members the right to apply the exchange rate system of their choice, and (2) commit member countries to cooperate with the Fund and with other member countries to promote orderly exchange arrangements and a stable system of exchange rates. In fulfillment of the latter obligation, Fund members undertake "to promote stability by fostering orderly underlying economic and financial conditions and a monetary system that does not tend to produce erratic disruptions" and to avoid the manipulation of exchange rates aimed at preventing effective balance of payments adjustment or to gain "unfair competitive advantage" over other Fund members. No definite return to fixed par values is envisaged, although the possibility for this exists in the reformed Articles under prescribed circumstances. For the indefinite future, therefore, exchange practices prevalent since early 1973-independently or indirectly fluctuating rates-are expected to continue.

Thus, the reform implies the formal recognition of a modification in the general policy stance toward exchange rate matters characteristic of the par value ena. The attitudes of this period were exemplified by the reluctance countries frequently displayed to undertaking changes in par values, the attendant stigma that was, rightly or wrongly, associated with par value changes, and the tendency often to "defend" unrealistic rates. Whatever the particulars of the exchange arrangements that countries will adopt and maintain, it seems clear that the general acceptance of fluctuating rates will make them a more frequently used instrument (at least on the part of major trading nations), whether this takes the form of tolerating market-induced changes or the encouragement, through official exchange actions, of movements in exchange rates.

The recent ascendancy of fluctuating exchange rates cannot, of course, be considered in a vacuum. Any prevailing system of exchange rates must be related to the general economic context within which it operates. Some of the underlying causes of the breakdown of the Bretton Woods system continue to persist, and in certain areas (such as differing rates of inflation) may have become more pronounced during the period since 1971. To this extent, fluctuating rates are a reflection of continued instability in the international economy (and hence the importance of the obligation, under the reformed Articles, to promote policies aimed at fostering underlying economic and financial stability). But at the same time fluctuating rates perhaps offer an easier method of coping (or appearing to cope) with balance of payments disequilibria than would fixed rates under the same conditions.

In these circumstances, it may safely be deduced that changes in exchange rates will in future be accorded a more prominent role in adjustments of balance of payments disequilibria. This is not to say that one has arrived at the purist's free floating paradise where variations in the exchange rate assure permanent balance of payments equilibrium. But fluc- tuating exchange rates do, a priori, imply prompter responses to payments disequilibria and, ceteris paribus, a reduction in the magnitude of imbalances (in terms of reserve movements).

\section{Effects on world trade}

The implications of fluctuating exchange rates for world trade will be of two major kinds, those of a financial character and those relating to commercial policy issues. (In addition there will be a number of purely technical questions such as the system of valuation of imports for customs purposes.)

The financial implications (with which we are not concerned here) arise from the possibility of sudden and unpredictable changes in exchange rates. These, on the one hand, increase the financial risks of international trade and, on the other, change the character of the currencythe international currency-in which trade is conducted. Frequent variations in the value of such a currency will make it less attractive as a unit of account, a store of value, or a standard for deferred payments, and thus less useful as a currency for trade transactions. The financial implications of exchange rate variations can, of course, to some extent be overcome by forward exchange operations where such facilities are available.

Our main interest here, however, is the possible commercial policy consequences. One major implication is that fluctuating rates may tend to diminish the importance of tariff duties as a tool of commercial policy relative to nontariff measures, in particular quantitative restrictions. (All references to tariffs are to ad valorem rates. Most tariffs of industrial countries are "bound" under the General Agreement on Tariffs and Trade (GATT), which means that the maximum levels of duty have been fixed by negotiation and formally incorporated in a binding legal document. Such duties may be freely reduced, but they may be raised only through renegotiation or the granting of a GATT waiver. Surcharges on "bound" items are contrary to GATT rules.) Unless one makes the unrealistic assumption that tariff rates are flexible and will change pari passu with exchange rates so as to keep the level of protection unchanged, then tariffs as a protective device will lose some of their value since the level of protection they will afford will be haphazard-too much or too little-and constantly changing as the exchange rate fluctuates. In particular, tariffs may become a less reliable device 
for protecting domestic industries in situations of large exchange rate fluctuations or a rapidly depreciating or appreciating currency. In both of these situations exchange rate variations could "overwhelm" any protection afforded by the tariff duty (a large appreciation could eliminate, and a large depreciation increase, the protective element).

The above argument, of course, needs considerable qualification. First, we are only referring to the protective role of tariffs, whereas tariffs can have other
Changes in par values (especially of major currencies) were infrequent and consequently the protective value of tariffs was maintained against erosion (or accretion). through exchange action for long periods of time.

The corollary to the argument presented above is that nontariff measures may tend to become relatively more attractive since they (in particular, quantitative restrictions) may offer more assured protection, irrespective of the behavior of the exchange rate. In the face of fluctuating

\section{"the significance for world trade of the agreements reached at Jamaica lies not only in the formal recognition of fluctuating rates, but also in the commitment not to manipulate exchange rates for commercial advantage"}

effects such as revenue, consumption, and redistributive effects. Second, the causes of exchange rate changes must be taken into account. To the extent that exchange rate fluctuations reflect changes in rates of inflation, then the protective effect of given tariffs will be unaffected by exchange rate changes. Similarly, changes in exchange rates that correspond to differences in productivity growth may restore the protective value of tariffs to their "required" level. In reality, exchange rate fluctuations may reflect a number of factors (or a combination of these): different rates of inflation, productivity changes, short-term capital movements, noneconomic factors, etc. But unless one or other of the extreme cases is assumed (for instance, exchange rate variations corresponding only and fully to different rates of inflation), then there is some force to the argument presented above.

A third important qualification is that the argument, to the extent it is valid, applies only to changes in the level of protection for the economy as a whole. In other words, while exchange rate variations may bring about changes in the level of protection afforded to traded goods as compared with nontraded goods, they will not affect the relative rates of protection between different traded goods, these being determined by the structure of tariffs.

It may, of course, be argued that even under fixed rates the protective value of a tariff changes when the exchange rate is changed. However, under the par value system, exchange rates were assumed to be fixed and changeable only when a "fundamental disequilibrium" developed. become attractive to some countries, although the protection provided will be of a less selective type than that afforded by tariffs. Hence the significance for world trade of the agreements reached at Jamaica lies not only in the formal recognition of fluctuating rates, but also in the commitment not to manipulate exchange rates for commercial advantage and, more broadly, in the agreement to cooperate with each other and with the Fund to bring about stable exchange arrangements and to promote policies aimed at underlying economic and financial stability. Equally important will be the role of the Fund in its exercise of "firm surveillance" over exchange rate policies.

\section{Trade negotiations}

A second aspect of the commercial policy implications of fluctuating rates relates to the trade negotiations. The institution of fluctuating rates and the possible greater relative importance of nontariff restrictions as commercial policy tools, may have a bearing on the multilateral trade negotiations now under way.

Among the complex and interrelated factors underlying a country's trade negotiating stance there may often exist a certain reluctance to engage in trade liberalization for fear of its potential balance of payments effects. In particular, countries may be reluctant to relinquish altogether the freedom to grant protection to selected sectors of the domestic economy. As regards the first consideration, fluctuating rates should help counteract the resistance to trade liberalization if it is assumed, as in this article, that their enhanced role in the balance of payments adjustment process would be a factor for more automatic adjustment. This would be especially so if, because of certain structural factors, reciprocal trade concessions would, under fixed rates, have been anticipated to result in a deterioration of the balance of payments.

International tariff negotiations in the GATT were traditionally based on reciprocal trade concessions, granted in a bilateral or multilateral framework, which were then generalized through the mostfavored-nation formula. With the move toward across-the-board tariff cuts and the increasing importance of nontariff measures, reciprocity as a method of trade negotiation has become less significant although it remains important as a guiding principle in the negotiations among industrial countries. (The Tokyo Round explicitly provides that developed countries should not expect reciprocity 
from developing countries in the negotiations.)

In the light of this, the argument had sometimes been advanced that reciprocity in trade concessions might well lead to a deterioration in the U.S. balance of payments because of certain characteristics of U.S. trade, namely, that U.S. exports are heavily concentrated in agricultural and high-technology products and thus have a low price elasticity of foreign demand, while the price elasticity of U.S. demand for foreign imports is high. Accordingly, a mutual reduction of trade barriers between the United States and its major trading partners would, it was argued, have a built-in bias toward imbalance in the U.S: balance of payments.

Assuming that the underlying economic reasoning is valid, it may be argued that the institution of fluctuating rates has attenuated this problem since, a priori, the task of maintaining overall balance of payments equilibrium should be easier under fluctuating rates and hence the possible balance of payments consequences of trade liberalization should cause less concern. Second, unless one assumes foreign demand for U.S. products to be totally inelastic with respect to price and U.S. demand for imports to be infinitely elastic, then the advent of fluctuating rates introduces a new dimension. Prices of foreign goods in domestic currency and of U.S. exports in foreign currency will be affected not only by relative rates of inflation, productivity growth, and changes in tariff rates, but in addition by changes in the exchange rate.

Fluctuating rates may, therefore, in a sense, be said to "liberate" trade negotiations from some of the obstacles that might have been posed by fears based on uncertainties of balance of payments developments and to give a degree of freedom to tariff negotiations analogous to the freedom they are assumed to give to the conduct of domestic economic policies.

As to the other consideration underlying a country's negotiating stance mentioned above, that concerning freedom of action for protection of domestic industries, the impact of fluctuating rates could work in an opposite direction to the one described above-fluctuating rates might indirectly be a force militating against trade liberalization (considering trade liberalization in the broader context of all barriers to trade). If, as argued above, tariffs become a less attractive commercial policy tool as compared with nontariff measures, then those countries that are reluctant to grant trade concessions on protective grounds may be even more hesitant to liberalize their nontariff restrictions if these measures are conceived as the principal effective protective policy instrument.

The force of this argument depends, of course, on the emphasis that is placed by negotiating countries on retaining some protective measures even though the central purpose of trade negotiations is the liberalization of trade. To the extent that such a policy stance prevails, it could affect negotiations not only in the field of nontariff barriers, but also as regards any "code of behavior" that may be discussed relating to protection of domestic industries from import injury (the socalled "safeguard" clauses).

\section{Tariff and nontariff measures}

To turn the question around, reference must also be made to at least one area where the outcome of the current trade negotiations will have an important bearing,for the monetary arrangements that have emerged from the reform exercise. The possible greater degree of importance accorded to nontariff as compared with tariff measures as tools of commercial policy has an important bearing on the balance of payments adjustment process under fluctuating rates. Fluctuating exchange rates imply, as already stated, that movements in exchange rates will play a more prominent role in the adjustment of the balance of payments than would be the case under fixed par values. If, however, for whatever reason, countries continue to rely on, or increase, quantitative and other nontariff restrictions on trade, then the above-mentioned role of exchange rates is substantially compromised in that fluctuating rates would have to restore equilibrium through their impact on only those goods that are not subject to nontariff restrictions. The greater the expanse and depth of such restrictions, the narrower the range of goods that would be responsive to exchange rate movements and market forces and thus the greater the burden of adjustment placed on these pricesensitive goods.

The consequence of the above is that nontariff restrictions could seriously impede fluctuating rates from the adequate performance of their appointed duties and could render adjustment more difficult and probably more lengthy (unless nontariff restrictions work in the same direction as exchange rate changes). Furthermore, the placing of an undue share of the adjustment burden on the price-sensitive sector would lead to additional distortions and misallocation of resources. For the Jamaica accords to function at full efficiency, it is therefore important for the trade negotiations to succeed in liberalizing nontariff measures and establishing a code severely controlling such practices.

\section{Outcome}

From this article, the inference may be drawn that, as a result of the separate and uncoordinated reform of the world trade and monetary system, one may be faced with an apparent dilemma, namely that the reduction or elimination of nontariff restrictions (in particular quantitative restrictions) to international trade is a precondition for the optimum performance of fluctuating rates but that, because of the regime of fluctuating rates, these very nontariff measures may tend to assume greater importance as instruments of commercial policy.

No attempt has been made in this brief analysis to provide empirical evidence in support of this apparent dilemma and therefore it is open to conjecture whether in fact the points raised pose any problems of substance. The subject is complex; one important consideration when studying it further would be to establish the degree of international trade that is truly free of nontariff barriers. This task would be rendered difficult by lack of information, the multiplicity of nontariff barriers, and the existence of many forms of disguised trade restricting devices. Another consideration would be a determination of the importance accorded by trading nations to nontariff measures from a commercial policy point of view. While there is evidence that some countries have moved toward greater restrictiveness in trade, it seems that this has been mostly motivated by the effects of the world-wide recession of 1974-75 rather than by fluctuating rates.

The multilateral trade negotiations have a long way to go and, in spite of the limited progress to date, their outcome, in particular as regards liberalization of nontariff measures, should not be prejudged. In the monetary field, it is not possible at present to say whether the relatively large exchange rate fluctuations of recent years will continue or whether conditions will settle down to greater stability. A favorable outcome in either of these two spheres would largely reduce the significance of the apparent dilemma referred to above. 


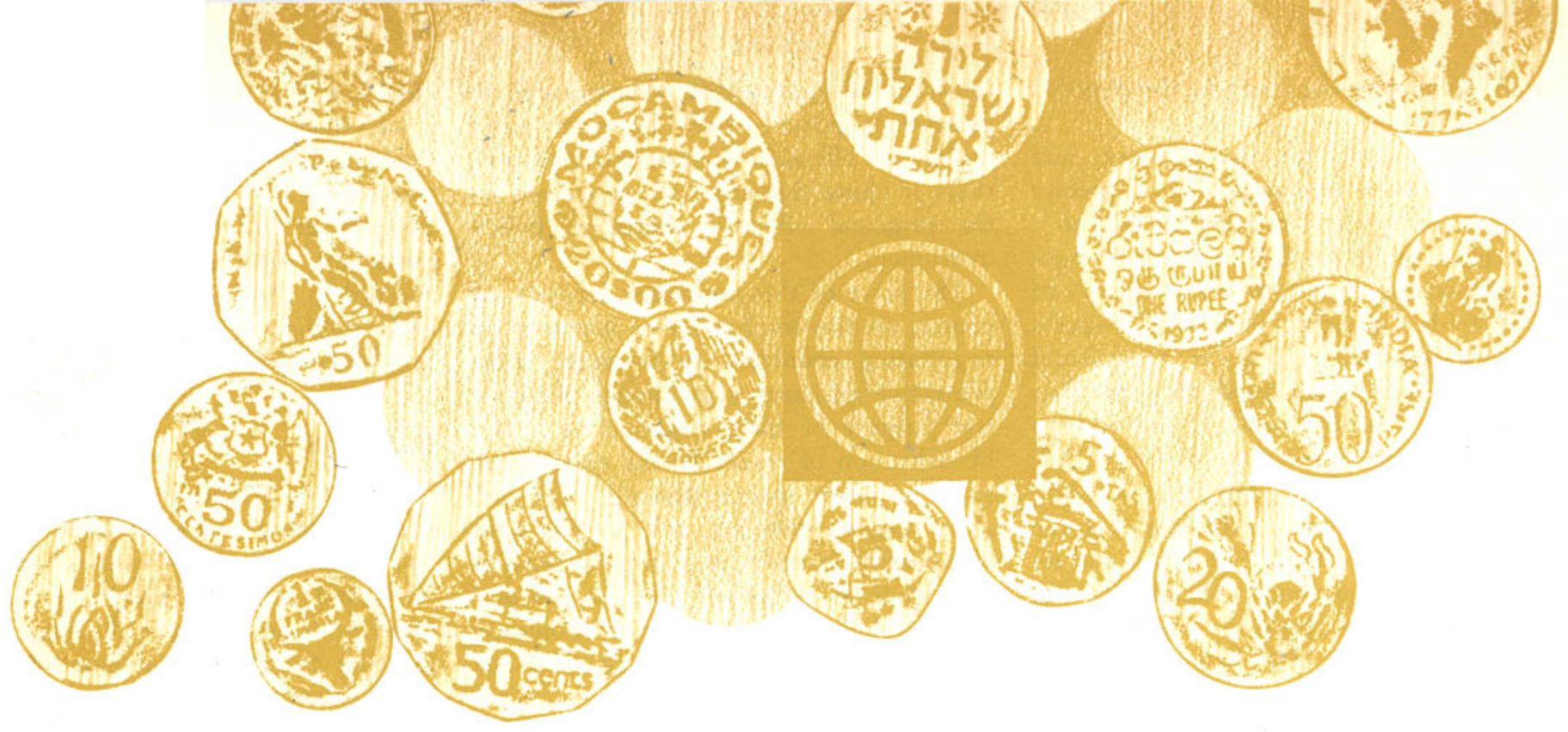

\section{The World Bank- a financial appraisal: II}

\section{This is the second of two articles on the Bank's financial operations. It covers the Bank's lending policies, the credit- worthiness of borrowers, project appraisal, and the role of the International Development Association. \\ The first article appeared in the September 1976 issue of Finance \& Development and covered the liquidity policies, borrowing program, and capital structure of the Bank.}

\section{Eugene H. Rotberg}

The financing of economic development is one of the principal purposes for which the Bank was established. The care employed in managing the Bank's finances and borrowings is directed toward ensuring that it will be able to raise sufficient funds to finance its development program. That is its basic job. The future of the Bank ultimately depends on the policies and practices that govern the quality of its lending. To maintain the continuing support of its member governments, its loans must stimulate economic growth in the less developed countries where it lends. At the same time, it must satisfy those from whom it borrows its funds that it will meet its obligations.

The lending operations of the Bank are different from those of the private market. How are they different? Loans must be granted on a basis of sound financial and economic analysis; the projects must produce an acceptable rate of return; and, in each case, the prospect for repayment must be apparent. Bluntly put, the Bank has proven to be a tougher, harder lender than many commercial institutions. It asks that are relevant to the making of loans but are rarely dealt with by commercial institutions.

Over 90 per cent of the Bank's loans are committed to the financing of specific development projects. The Bank does not lend in support of military or political objectives, or for the purpose of facilitating exports of any particular industrialized country. Of the $\$ 29$ billion equivalent in loans committed by the Bank over the past three decades, including the $\$ 2.5$ billion sold to third parties, a total of almost $\$ 7$ billion has been repaid. Disbursed and outstanding loans held by the Bank on December 31, 1975 amounted to over $\$ 12.6$ billion, and a further $\$ 9.4$ billion of committed loans had not yet been disbursed.

A broad spectrum of projects is financed by the Bank. They are in such sectors as agriculture and rural development, industry, power, telecommunications, transportation, education, urban development, and water supply and sewerage. Education, for example, is essential for raising the questions and receives answers on issues level of competence and increasing the skills necessary for implementing economic development. Improvements in urban areas and in water supply and sewerage facilities contribute to the health and well-being of people in developing countries and, therefore, to their productive capabilities.

It is reasonable for potential lenders to the Bank to raise questions about the creditworthiness of the governments to which the Bank lends. The World Bank makes loans to borrowers who cannot obtain the funds on reasonable terms elsewhere. There is no pretense that the Bank can predict with certainty which borrowers 10,15 , or 20 years from now will be creditworthy. The discussion here centers on what the Bank's several hundred economists and financial analysts look at in evaluating the creditworthiness of a potential borrower.

The Bank staff examines the country's per capita income, and its potential for the future. It looks at the country's population growth, its savings rate, and the vehicles through which savings occur. It examines the country's foreign exchange position, its sources of borrowing, its tax base, and its terms of trade. The staff closely monitors the potential borrower's external debt-its interest and principal requirements for the immediate and foreseeable future. It studies the country's reliance on export commodities, whether one or several, and prepares the economic analyses required to show how the country's exports could be affected by declines in international commodity prices. It examines the country's imports, and whether imports could be curtailed in order to conserve the necessary foreign exchange to meet debt obligations. It examines the country's tariff structure, its 
eliance on food and energy imports, its overall economic health, and the relative commitment of resources to productive and unproductive projects. The Bank insists on receiving and has the right to receive this information. There are few commercial institutions or governments which are equipped to make this kind of creditworthiness study before making a loan.

There is no incentive to do other than make the right determination as to whether or not a country will be able to service its debt to the Bank. A significant portion of the Bank staff is committed to that responsibility, and, if sufficient doubt exists, the country does not receive a Bank loan. A great deal of time, effort, energy, and intelligent thinking goes into making decisions which are for the benefit of both the borrower and the bondholder.

\section{Project appraisal}

Nor is the Bank's interest limited only to questions of the creditworthiness of potential borrowers. The staff carefully appraises all projects for which a loan is proposed. This involves investigation of various aspects of the project: economic, technical, financial, organizational, managerial, and operational. Examination of the economic aspects includes a determination of whether or not the benefits and rate of return will be worth the cost. The technical study involves investigation of the project's feasibility, its merits, and whether the technical solution proposed is appropriate. The project must be of high priority to the economic growth of the country. If it is not, the Bank will not finance it.

The staff also reviews with the government its long-term plans to determine whether the project, at a particular point in time, fits into the country's economic development program-whether it comes too early, or whether it simply will not work until other fundamental changes are first made in the country's economic or social structure. Here, too, there is no incentive other than to make the most meticulous technical analysis of the specifics of each project. The financial aspects are appraised with a view to ensuring that the financial conditions for sound implementation and efficient operation can and will be met by the borrower. In appraising the organizational, managerial, and operational aspects of a project, the Bank is particularly interested in the competence of the management to implement the project and to operate it after completion. Ultimately, the willingness of a country to want to continue to meet its obligations will depend on its evaluation of the staff's intelligence and objectivity, and on its desire to obtain financial and technical assistance from the Bank.

The Bank's interest in its loans does not dwindle down to collection of principal and interest once the loan contract is signed. The Bank is very much involved in ascertaining that the loan proceeds are spent efficiently and economically and for the purposes intended. To ensure that borrowers obtain goods and works for Bank-assisted projects at reasonable prices and on favorable terms, the Bank requires in most cases that procurement be made through international competitive bidding (reviewed by the Bank) open to suppliers in member countries and Switzerland. The Bank is concerned that the projects it supports be soundly executed. Accordingly, it requires the borrower to submit reports on the progress of a project. Bank staff-visit the project periodically to examine physical construction or operations, the borrowers' accounts, the use and maintenance of equipment purchased with the proceeds of Bank loans, and the effectiveness of the project management. The point of all this is to be in a position to identify, at an early date, any problems that arise, and to discuss and resolve them with the borrower.

Disbursements of loan proceeds are carefully scrutinized and are made only on receipt of documentation that the goods and services being paid for are covered by the loan agreement and have been procured in accordance with its terms. The Bank controls the disbursements of the loan; it does not hand over the proceeds of the loan when the agreement is signed. A typical Bank loan takes seven years to disburse fully, during which period the Bank receives a commitment fee on the undisbursed balance. The Bank, therefore, reviews the invoices, pays them, and then notifies the borrower that disbursement has been made on the loan. Interest is payable on that portion of the loan from that point onward.

Unlike some commercial banks and bilateral lenders, the Bank seeks no political or trade commitment as the price for a loan. Admittedly, mistakes have been made. But they have stemmed from the human frailty of not knowing the optimum means to facilitate economic development, and not from a desire to control a country's political future. Project appraisal and evaluation take considerable staff commitment, but that is what the Bank is all about. It commits 20 times more in staff time to evaluating countries and projects before, during, and after a loan is made than it does to the raising of funds or the investment of liquid resources. And that is the way it should be.

\section{No defaults on loans}

What has this commitment produced? The Bank has not had any losses on its loans. It has never had a write-off of a loan. The Bank has a firm policy against debt rescheduling, and does not tolerate late payments. In December 1975, on the occasion of the Bank's most recent public bond issue in the United States, of the $\$ 12.6$ billion in loans then disbursed and outstanding, none was over 30 days late either in interest or in principal. And while Bank financial statements include a "general reserve" (previously called "reserve against losses on loans"), that item constitutes, in fact, accumulated retained earnings. The Bank has no actuarial basis for its "reserves" simply because it has never had a bad loan. That is not to say that it never will have a "bad loan." But the point is that borrowers have seen fit to maintain impeccable financial relationships with it.

There are substantial pragmatic reasons why borrowers do not default on World Bank loans. In the event of a default, no further disbursement would be made on that loan or on any other Bank loan that was outstanding in the country. And, no new loans would be committed until the default had been corrected. Borrowers know Bank policies in this regard, and given the substantial amount of undisbursed loans, they would be extremely reluctant to take steps to jeopardize the transfer of future resources.

A default to the Bank also carries serious consequences which would affect the credit of the country involved, both with other countries and with commercial suppliers of resources. If, for example, principal and interest payments on loans are even 30 days late, the Executive Directors of the Bank, who represent all 127 member governments, are formally notified of the delinquency.

As noted, the Bank, after 30 years of lending, has yet to experience a write-off of a loan. There have been numerous changes of government in member countries, including change by armed revolution, coup, or assassination. The successor government, however, has always honored its predecessor's obligation to the Bank. This attitude is engendered not only by the sanctions inherent in a default to the Bank, but also by the Bank's nonpolitical approach to the granting of loans, and by the fact that the projects financed make sense in that they contribute materially to 
economic stability and growth in the countries where they are located.

It would be fair to say that borrowers trust the Bank. They trust its objectivity, its fairness, and its commitment simply to do the right thing. They want to maintain a relationship with an institution which does not attach political strings to loans and which has a competent body of professionals whose role is to make decisions on strictly economic and financial grounds. For some borrowers, it is that-pool of intelligence and objectivity which is as important as the actual transfer of monetary resources. And the borrowers know that those resources will no longer be available to them should their relationships with the Bank become less than impeccable.

Nonetheless, I am asked sometimes what impact a default would have on the finances of the Bank and on its ability to meet service on its indebtedness. Let us take one exaggerated example. Assume that a sizable borrower repudiates all of its debt to the World Bank and stops payment of debt service immediately. The effect of this action might be that the Bank incurs a loss against its current income.

As far as the ability of the Bank to meet service on its debt is concerned, however, the default would have little, if any, impact. In the immediate period following the default, the Bank's cash flow very likely would increase, since all disbursements on loans to the defaulting country would be stopped. Further, since the debt structure of the Bank consists primarily of long-term and intermediate-term obligations, the effect on the market of the Bank's outstanding obligations would be minimal. It would be a nonevent in terms of its effect on the Bank's bondholders. The Bank's reserves are adequate. Its capital is huge. And, most important for the bondholder, the very real and substantial liquid position of the Bank of over $\$ 6$ billion, as well as its access to worldwide markets, affords protection not available elsewhere. The uncalled capital is merely icing on the cake. All of this is available, along with the cash flow from the repayments of the pool of disbursed loans, to support the credit of the Bank and the security of those who invest in its bonds and notes.

\section{The role of IDA}

The International Development Association (IDA) was established in 1960 to assist in financing economic development in those developing countries whose ability usefully to employ externally borrowed funds exceeds their ability to service such borrowings on conventional terms, including the terms of World Bank loans.

Membership in IDA is open to all members of the World Bank, and 116 of them have elected to join. Eligible recipients of credits, however, generally are those poorer developing countries which have an annual per capita gross national product of $\$ 375$ or less. The funds employed by IDA in its credit operations-they totaled $\$ 11.5$ billion at the end of 1975 - come mostly from the 21 industrialized and highly developed members including the United States. In addition, an aggregate of $\$ 1.02$ billion has been provided by the World Bank in the form of grants to IDA. These grants have been made from the Bank's net income in each of the fiscal years 1964-75, after prudent allocation of net income to reserves. And only that portion is available to IDA which otherwise might have been appropriate for dividend payments.

IDA is administered by the same management and staff as the World Bank. The Association has been called "the World Bank's soft loan window." It is true that IDA's terms to its borrowers are highly concessional-50 years to final maturity and a service charge of only $3 / 4$ of 1 per cent a year-but there is nothing "soft" about the credits themselves. The same rigorous standards that are applied to projects supported by Bank loans are applied to projects supported by IDA credits. The difference is that the countries receiving IDA credits are not creditworthy for a loan on the Bank's conventional terms. It should be stressed that if funds become unavailable for IDA operations the World Bank will not lower its creditworthiness

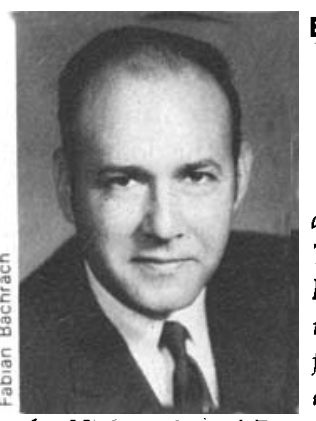

\section{Eugene H. Rotberg}

\section{the University of Pennsylvania. Prior to} coming to the World Bank, he served with the U.S. Securities and Exchange Commission, holding positions as Chief Counsel for Policy Research and Associate Director for Market Regulation. Mr. Rotberg has taught law and lectured extensively in universities on matters dealing with capital markets and the World Bank. standards to make up the shortfall.

Though the same personnel administer both the World Bank and IDA, the two institutions are legally and financially separate entities. This includes separation in respect to assets, liabilities, and capitalization. The Bank's credit is in no way involved with IDA. The Bank cannot lend to IDA. Whatever financial questions might arise in connection with IDA, it is the Association's member governments that are at risk, not the World Bank or the investors in its securities. This means that institutions or individuals which lend to the Bank are not at risk by reason of IDA's activities. The poorest countries are primarily recipients of IDA credits. The credits extended to them in no way jeopardize the Bank itself. On the contrary, for those countries which have outstanding Bank loans and which now are receiving IDA credits, these credits enable them to obtain the services and experience of the Bank's staff and the planning, implementation, and financing of development projects at very low cost for 50 years.

Thus, there are substantial advantages from IDA accruing to the World Bank and its creditors, since Bank loans are reinforced by the financial and economic benefits flowing from IDA-supported projects. IDA's funds, of course, come, for the most part, from the taxes of the richer countries; to that extent, taxpayers have a major interest in its operations. IDA does cost the taxpayers something, but in no way does it add to their risk as World Bank bondholders. On the contrary, it reduces it. Any of the poorer countries qualifying for IDA assistance which had an outstanding Bank loan would seriously hesitate before defaulting on it lest it jeopardize the interest-free 50-year development credits from IDA.

\section{Financial environment}

Some reference should be made to the financial environment in which we live, as it affects the investment climate generally and the attitude of investors toward the World Bank. Despite the financial strength of the Bank and its commitment to prudent financial policies one would be less than frank, and indeed, quite naïve, if one assumed that it was recognized by the whole investment community in, say, the United States, as the only premier credit in the marketplace. For example, the Bank does not trade in the market at the same yield as direct obligations of the U.S. Government. The Bank has neither taxing power nor the power of the printing press, nor is it a household name. Few people 
understand what the Bank does, and fewer still have any conception of its financial structure or financial policies. The Bank is a fairly complicated institution and portfolio managers, given a bewildering variety of potential alternatives, sometimes feel more comfortable with an investment which they can clearly categorize as "government," or "foreign," or "utility," or "industrial." It is a sad, but probably accurate, commentary that some investment managers cannot and do not explain the Bank to their Boards of Directors or their policymakers.

Further, the reaction of the financial community to exaggerated and often inaccurate public commentary about the problems of developing countries, defaults, possible debt reschedulings, expropriation of property, or political instability in some developing countries certainly does not contribute to a dispassionate evaluation of the Bank's credit. As overblown-possibly even irrelevant-as these matters might be to the financial strength of the Bank, the market's reaction to such talk is a factor in the establishment of the Bank's financial policies.

In a very real sense, these financial policies are based on the reality of the Bank's environment. The Bank, therefore, conducts its operations and maintains financial policies which recognize that the Bank's financial structure and strength may not be fully understood; that questions have been raised about its lending policies which may be based on inaccurate perceptions of the operations of the Bank; and indeed that there may be some hostility even toward the role of the Bank. Despite the Bank's successes in coping with these sometimes subliminal, sometimes expressed concerns, it will not conduct itself as if the perception of investors will always be rational and based upon fact. The assumption is that both investment managers and the Bank will make mistakes. Therefore, the financial policies of the Bank are designed to permit the flexibility necessary to operate successfully in difficult environments. That is why the Bank has built the overwhelming financial strength described in this article and that is why it intends to keep it that way and maintain its standing as one of the strongest financial institutions in the world. The World Bank is not a social welfare agency committed to making transfer payments to solve the problems of misery or poverty. It is a development bank using the most sophisticated techniques available to facilitate development while providing unmatched protection and strength for creditors and shareholders.

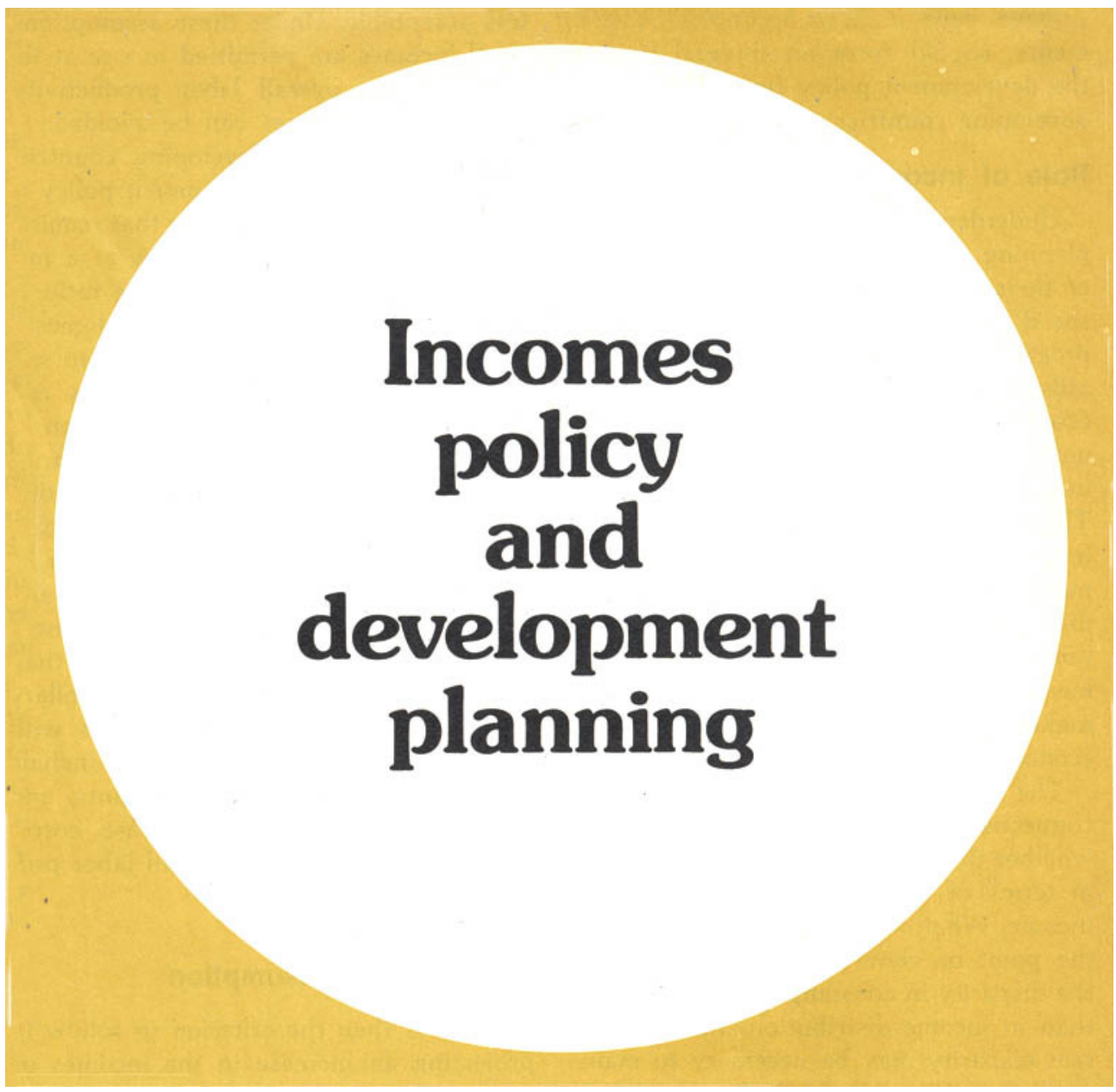

Incomes policies have been frequently considered as a tool for controlling inflation. The author analyzes incomes policy in relation to development planning and to the unemployment problems of the LDCs.

\section{V. Bhatt}

A number of industrially advanced countries have become increasingly aware of the need for a conscious incomes policy if they are to attain full employment, growth with relative price stability, and a viable balance of payments. Such an incomes policy would have to bring within its purview not only wage and salary incomes but also all other types of income, and it has become obvious that this sort of policy cannot be evolved and enforced without popular consensus on objectives and instruments.

In view of this move toward incomes policies in the industrial world, it is somewhat surprising that there is hardly any discussion on their relevance for the less developed countries (LDCs), where the need for them is much more urgent than in the industrial world.

With their labor forces growing at more than 2.5 per cent a year on top of a con- siderable backlog of underemployment and unemployment, developing countries are faced with an acute employment problem. Because of trade union activity and government legislation, money wage rates are nearly three times labor productivity and wage rates in the traditional sector. This has two effects: it induces migration from rural to urban areas; and at the same time it makes it difficult to increase employment in the modern sector at the rate required. Open unemployment in urban areas and worsening living conditions among small farmers and the landless labor in the rural areas are the inevitable consequences of this situation.

If this socially explosive situation is to be avoided, it is essential to regulate the level and pace of increase of money wages in the modern sector, and at the same time to increase the growth rate of employment and capital formation. 
Incomes policy, and its appropriate instruments, should form an integral part of the development policy framework in the developing countries.

\section{Role of incomes policy}

Underdeveloped countries have been planning for a structural transformation of their economies so as to attain certain social objectives. These generally aim at a progressive improvement in living standards through a self-sustaining process of economic development. This requires not only an accelerating increase in national income but also its equitable distribution. The objective of raising per capita income levels is normally specified in plan documents, while the objective of equitable distribution is often just mentioned but not translated in terms of any precise measurable index. This lack of clarity makes it difficult to formulate rational economic policies.

The pertinent question that arises in connection with income distribution is whether this objective should be expressed in terms of consumption or in terms of income. What seems to be important from the point of view of equity is to reduce the disparity in consumption levels, rather than in income distribution, where a certain disparity may be necessary to maintain incentives to save and to work. In fact, an attempt to reduce income disparities beyond a certain point may result in lower consumption levels for the low income groups in absolute terms over time than the levels they could reach if such income disparities were maintained.

Thus, assuming that $e x$ ante investment does not exceed ex ante saving and capital inflow, and given the objectives of planned economic development, the purpose of an incomes policy should be: (1) to prevent the emergence of inflationary pressures; and (2) to ensure that the consumption pattern that emerges is consistent with the objective of even income distribution. What, then, should be the guidelines for the developing world in formulating an incomes policy?

\section{Not labor productivity}

In the industrial countries, the major guideline that is generally accepted relates to the increase in overall labor productivity in the private sector (excluding government services). If all incomes increase at this rate, it is likely that no inflationary pressures will arise in a closed economy. This is true, however, only under the following assumptions: provided there is no overall excess demand; and provided the present income distribution is more or less acceptable. Under these assumptions, if all incomes are permitted to rise at the same rate as overall labor productivity, inflationary pressures can be avoided.

However, in the developing countries it is the essence of development policy to bring about structural change that requires saving and investment to grow at a rate higher than income. Further, the ratio of government revenue to gross domestic product (GDP) needs to be raised to satisfy the demands for public goods and particularly the collective consumption of the poor. Both these conditions can be satisfied only if private consumption increases at a rate lower than the increase in overall labor productivity. This can be ensured if the incomes of the saving and investing classes (including government enterprises) increase at a rate higher than overall labor productivity. As a corollary to this, the incomes of the classes with low saving propensity (which include landless laborers, domestic servants, and industrial labor) should increase correspondingly slower than overall labor productivity.

\section{Increase in consumption}

What is then the criterion to follow in projecting an increase in the incomes of the nonsaving classes? In simple terms, the total income for all these classes should not grow at a rate higher than the planned rate of increase of private consumption.

This does not mean that all wage rates can rise at this rate. For even when the wage rates do not rise, any shift of labor from low-wage to high-wage occupations causes total wage incomes to go up. In the urban-industrial areas, the proportion of labor in the high productivity sectors would increase with economic develop-

\section{V. Bhatt}

from India, is a Division Chief in the Public Finance Department of the World Bank.

Before joining the

Bank staff in 1972, he was General Manager of the Industrial Development Bank of India, and Economic Advisor at the Reserve Bank of India. Mr. Bhatt is the author of several books and articles. ment, and thus the average wage rate would increase even if productivity in different sectors remained the same. However, this shift would probably be more than offset initially by a relative increase in the labor force in the lower wage scales as a result of rural-urban migration. Thus, the effect of these different shifts may cancel each other out, and the average wage rate may remain constant in the urban industrial areas. However, the average wage rate of both the rural and the urban sectors together would tend to increase. Thus, per capita consumption of the wage-earning classes would increase. Hence, the wage rates in the different occupations can be raised only at a rate that is lower than the rate of increase in per capita private consumption.

There is, however, one further consideration to be taken into account. Urban wage earners do save a part of their incomes in the form of their contribution to the various social security schemes like provident fund schemes, while the rural workers have no such schemes. Hence, though a relative shift of labor from the rural to the urban areas would tend to raise the average wage rate, the average rate of consumption per worker might not increase in the same proportion. Further, if the provident fund contribution is raised so as to increase the savings/ income ratio of the urban wage earners, the wage rates can be allowed to rise at the same rate as in per capita private consumption.

In any case, an increase in wage rates above this limit could be viable in terms of the development objectives only if the rate of growth in per capita consumption of the other classes-self-employed farmers, high-income salary earners, selfemployed businessmen, professional people, and other high-income nonsalary earners-is lower than the rate of growth of per capita saving. This can be done by inducing, in a variety of ways, these classes to save a larger proportion of their incomes.

One way in which the growth rate in the per capita consumption of these classes can be reduced is to tax heavily all functionless incomes. In this category would come all households receiving incomes/capital gains on the basis of ownership of urban land and such households that receive large fortunes not through their own work or saving but entirely through gift or inheritance.

Thus, the rate of increase in average wage rates can be raised above the projected growth rate in per capita consumption only to the extent to which the other 
classes can be induced to save or pay out in tax a larger proportion of their income. However, there is a limit to the extent to which this can be done. As a guideline, therefore, it is desirable to increase wage rates only to the extent of the increase in per capita consumption.

\section{Agricultural wages, productivity}

Such a guideline, of course, assiumes that labor productivity in agriculture will increase at an appropriate rate. In the present context, this is a crucial assumption. Given the labor force in agriculture, and assuming that all increases in this labor force have to be absorbed in nonagricultural occupations, the real wage rate in the nonagricultural sector can increase only if the marketable surplus of food increases at a rate higher than the increase in the total labor force. For this, labor productivity in agriculture should increase at a rate significantly higher than the rate of increase in the total labor force. For example, if the labor force increases at 2.5 per cent a year, if per capita consumption is projected to grow at 2 per cent a year, and if the expenditure elasticity of the demand for food is 0.6 per cent, labor productivity in agriculture should rise at 3.7 per cent a year. Unless such an increase can be brought about, the real wage rate in the nonagricultural sector cannot rise; an increase in money wages would be offset by an increase in the price of foodgrains.

There is another consideration to be taken into account. If, in the example given, labor productivity in the agricultural sector was growing at an annual rate of less than 3.7 per cent, an increase in real wage rates would be possible only with considerable unemployment. Such unemployment would then depress the wage rates, particularly in the rural areas, and it would be the weaker sections of the community like the landless laborers whose conditions would deteriorate. Thus, there is a vital relationship among the rate of growth of labor productivity in agriculture, the rate of growth of employment, and the real wage rate. In order to improve the living conditions of landless labor, the productivity of labor in agriculture should increase at a rate high enough to raise their real wages and to support productive employment of the rising labor force. This is so unless the requirement of wage-goods can be met through imports against the exports of nonagricultural goods and services-a condition that is relevant only for city states like Singapore and Hong Kong or mineral producing countries like those of the Middle East.

The structure of wages and salaries in nonagricultural occupations is governed by the basic wage rate of unskilled labor and the relative scarcity of the personnel required. This structure may need to be rationalized so that for the same occupation the real income does not differ among industries or regions, unless there are other compensating factors operating.

Since the government sector is supposed to play a vital role in the planned process of development, it has to attract and retain an increasing corps of employees with an immensely wide range of occupational skills and abilities. The wage and salary scales of government employees are, therefore, important and some definite guidelines in this matter need to be thought out.

The foremost consideration here should be the ability of the government to attract the right type of skill and talent, and therefore government wage and salary scales should be comparable to the private sector for similar types of work and skill requirements. This is the principle of "fair comparison" as enunciated by the Royal Commission on the Civil Service (1955) in the United Kingdom, and which forms the basis of the Federal Salary Reform Act (1962) in the United States.

One of the essential points of this principle is that if the public services are to be efficiently manned, incomes policy must include a policy of competitive equality between public services and private employment within which they compete for recruits. If the public services are to remain efficient, they must follow an inflationary spiral if others set one going, but they should never set one off.

\section{Nonwage and salary incomes}

Since the saving-income ratio has to be raised progressively, the classes that are able to save will experience a more rapid rise in income than the wage and lowincome salary earners. What has to be ensured, however, is that these classes save such a proportion of income and in such forms as are required to attain the plan objectives.

The forms of saving that do not serve any development function are: excessive investment in residential construction used for conspicuous consumption; speculative holding of commodities; holding of gold; and speculative investment in urban land. Of course, if inflationary pressures are generally avoided, speculative holding of commodities will not take place.
The other functionless incomes arise from gift/inheritance of property. Such gifts and inheritance should attract a fairly high progressive tax. It may be argued that such a tax may prove to be a disincentive to save, because to be able to bequeath property to one's children is one of the most significant motives to save. However, to the extent to which this is a dominant motive, saving in fact could be larger because of the tax than it otherwise would be.

\section{Incomes policy and prices}

The success of the development effort depends on the extent to which incomes from the other productive forms of saving rise faster than national income, as long as the consumption of these classes grows, either at a rate lower than or similar to that at which per capita consumption is projected to rise. If these incomes are restrained by means of taxes or otherwise, the incentive to work as well as to save may be affected. What is necessary is not a restraint on the growth of these incomes but a restraint on consumption out of these incomes.

The rate of profit of a business enterprise, whether corporate or noncorporate, can be an index of its efficiency. However, if the enterprise is the sole producer of a particular good or service, and if it earns a high rate of profit simply because of its monopolistic position in the marketespecially in the field of essential raw materials and consumption goods-its monopolistic pricing may set off a pricewage or wage-price spiral. Such monopolies should be controlled in one way or the other.

There is another case where the market may need regulation. In a situation of increasing overall demand the rate of profit may be maintained or raised if business enterprises raise product prices and thus set in motion a price-wage and a wage-price spiral feeding on each other. If the wages are regulated, there is no reason why the enterprises should raise prices unless there is an unavoidable increase in some other costs. Therefore, attention should be paid to prevent business enterprises from raising prices merely to increase profits, particularly in the field of certain strategic commodities.

There should also be some regulation of prices of essential commodities and services produced by the factory type of business enterprises, in order to restrain those price increases that may be resorted to mainly for raising the rate of profit. With such regulation of price increases, 
and increases in wages and salaries, overall prices are likely to remain stable. Any increase in the rate of profit of business enterprises under such circumstances could arise only as a result of technical change and improvement in productive efficiency and would generally be accompanied by some reduction in the prices of their products. Such price reductions should be encouraged as they would be necessary to offset unavoidable price increases in some sectors and further to pass on a part of the benefit of improved efficiency to the consumer. The tax instrument can be used for this purpose.

However, the prices of industrial products will not remain stable if food prices increase relative to the prices of industrial products. If agricultural productivity increases at an appropriate rate continuously, food prices may not rise. But agricultural output fluctuates and will continue to fluctuate because of the vagaries of the weather. Hence, in a bad year, food prices will tend to rise and this rise will be aggravated because of the precautionary and speculative demand for food. An energetic buffer stock policy, therefore, is necessary if food prices are to be kept stable.

The relative prices of agricultural products have to be determined from the point of view of providing adequate incentives to the farmers to increase agricultural productivity at the required rate. The target for increases in the real wage rate of agricultural labor should also be one of the governing factors in determining relative food prices. The real wage rate of landless labor-as the weakest section of the community-should be raised faster than the real wage rate in the industrial sector. The industrial wage rate is almost three times that of the landless labor; this disparity is much too great and if continued it will tend to promote migration from the rural sector to the urban industrial sector at a rate which cannot be absorbed in productive employment and will create grave social and economic problems.

Once these relative prices are determined, policy measures should be effective enough to keep food prices stable. If the policy measures fail, and food prices do rise, there will be a demand for an increase in money wages. This demand will be legitimate to keep real wages stable and can be successfully resisted by a consensus only if the rise in food prices is expected to be temporary. However, if the rise is expected to be permanent, the choice will be between allowing money wages to rise and creating a wage-price spiral, and establishing some machinery for equitable distribution of food at stable prices. A continuous rise in food prices reflects imbalances in the development program; the attempt, therefore, should be such as to have a program that can be supported without a rise in food prices. If they are allowed to rise as a permanent feature of the development process, a wage-price spiral and the resulting socioeconomic tensions cannot be avoided.

\section{Collective consumption}

It has been seen that the average real wage rate should be allowed to rise only according to the projected rise in per capita consumption. The wage rate can rise faster only to the extent to which functionless incomes can be taxed and the consumption of such classes can be prevented from increasing. However, these measures would have only a once-and-forall impact: From a long-term point of view, the guideline should be as suggested.

However, with the rising proportion of government taxes to national income, the government would be able to increase the collective consumption of the community, particularly the consumption of the weaker sections of the community. Thus, the rate of increase in total consumption of the weaker sections would be higher than that of the better-off sections.

Collective consumption to improve the living standards of the poorer sections should take principally the following forms: free educational opportunities to improve their productive efficiency and thus to enable them to raise their living standards; free health services also to improve their productive efficiency; and, finally, to enable them to build their own houses, land should be made available to them at nominal cost and such savings institutions and instruments should be created as would induce them to save for building these houses. In addition, unemployment insurance and/or provision of employment opportunities would stabilize their incomes. All these, of course, can be accomplished only by stages, but a rational perspective plan should be formulated indicating clearly how and in what stages collective consumption would increase and how it would be directed principally toward improving the living conditions of the weak and vulnerable sections of the community. There should be a clear plan of action in this sphere if an incomes policy is to gain support from the wageearning classes.

\section{Oil income and financial policies in Iran and Saudi Arabia continued from page 15}

increase mainly through restraining the growth in public sector net domestic expenditures. The government budget provides for an unchanged level of total allocations, despite anticipated higher oil revenues, and a larger proportion of expenditure is expected to be disbursed abroad, including advance payments to contractors for several priority projects, particularly in the areas of housing, ports, and roads. Moreover, in May 1976 the Saudi Arabian Monetary Agency raised the minimum reserve requirements of commercial banks. While the increase in reserve requirements was moderate and will absorb only a small proportion of excess reserves held by banks, this action has signaled the need for banks to tighten credit.

In summary, the recent increases in petroleum prices have considerably enhanced the financial and foreign exchange positions of Saudi Arabia and Iran. However, the rapid expansion of government expenditures for the purpose of improving living standards, accelerating economic growth, and diversifying the productive base of the economy was confronted with serious physical bottlenecks-particularly manpower shortages and capacity limitations in the ports, inland transportation, and construction sectors. As a result, the ability to utilize oil revenues in a fully efficient manner was constrained, and both countries experienced imbalances in aggregate supply and demand and increased inflationary pressures. As the substantial alleviation of supply constraints was not feasible over the short run, the authorities in both countries have adjusted their financial policies and limited the growth of public sector net domestic expenditures in order to bring aggregate demand into line with resource availabilities and facilitate a more sustainable pattern of economic growth. 


\section{some projections for the developing world}

About 65 developing countries have adopted official family planning programs. The key activity in such programs is of course the provision of family planning services, a phrase which covers all forms of limiting births from the $\mu$ se of contraception, to sterilization and abortion. In the great majority of developing countries, contraceptive supplies must be imported-and paid for with foreign exchange, or received as a grant. Up to now, most contraceptives used in these countries have been given on a grant basis, but this situation will not continue indefinitely, and some time in the future the developing countries will have to bear the price alone. How much is it going to cost them? These tables show the findings of a recent study of the problem in 10 developing countries by the Population Projects Department in the Bank.

The study involved the following steps: (1) estimating the number of women who will be in the 20-44 age group between 1976-85, and the proportion who will either be married or living in culturally acceptable conjugal unions; (2) estimating the growth of contraception within the group of "married" women; (3) estimating the total cost of providing the contraception required by each country; and (4) estimating the maximum foreign exchange cost, assuming that all supplies will be imported. (Since this will obviously not be the case in all the countries, these estimates may be higher in some cases than the actual costs.)

Table 1 shows a range of high and low estimates of each country's total contraceptive costs, 1976-85, in 1975 values. The figures reflect estimates of rising usage, the most probable "contraceptive mix," and unit costs.

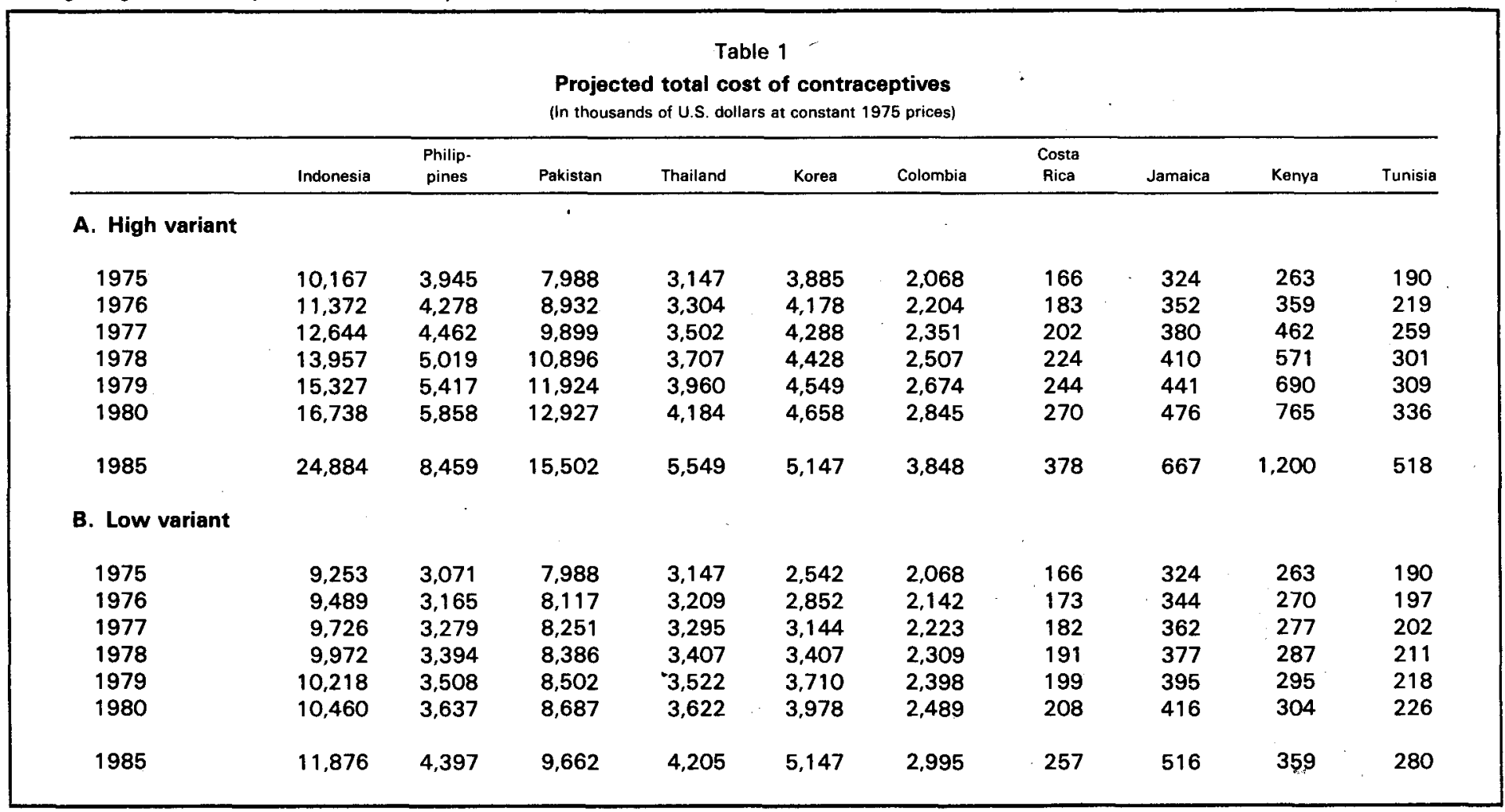

Table 2 shows (for the six countries for which estimates are available) what percentage of total imports would be accounted for by future contraceptive requirements.

Table 2

Projected total contraceptives' bill as proportion of total projected import bill (In per cent, shown for the high variant only, Table 1)

\begin{tabular}{lcccccccccc}
\hline & Indonesia & $\begin{array}{c}\text { Philip- } \\
\text { pines }\end{array}$ & Pakistan & Thailand & Korea & Colombia & $\begin{array}{c}\text { Costa } \\
\text { Aica }\end{array}$ & Jamaica & Kenya & Tunisia \\
\hline 1975 & 0.176 & 0.103 & 0.347 & 0.088 & 0.056 & 0.100 & 0.021 & 0.026 & 0.019 & 0.015 \\
1976 & 0.183 & 0.108 & 0.357 & 0.088 & 0.056 & 0.100 & 0.022 & 0.026 & 0.026 & 0.017 \\
1977 & n.a. & 0.108 & 0.393 & n.a. & 0.056 & 0.102 & 0.023 & 0.027 & 0.034 & n.a. \\
1978 & 0.194 & 0.113 & 0.447 & n.a. & 0.054 & 0.100 & 0.025 & 0.027 & 0.042 & 0.022 \\
1979 & n.a. & 0.116 & 0.472 & n.a. & 0.051 & 0.106 & 0.026 & 0.028 & n.a. & n.a. \\
1980 & 0.207 & 0.120 & 0.481 & n.a. & 0.050 & 0.093 & 0.027 & 0.029 & n.a. & 0.021 \\
1985 & 0.207 & n.a. & 0.423 & n.a. & 0.032 & 0.079 & n.a. & 0.025 & n.a. & 0.021 \\
\hline n.a. indicates data not available. & & & & & & & & & &
\end{tabular}

n.a. indicates data not available. 
Table 3 provides data for comparing present and future contraceptive imports with selected other categories of imports in the early 1970 s-no disaggregated estimates of future imports are available.

Table 3

Selected commodity imports ${ }^{1}$

(in thousands of U.S. dollars)

\begin{tabular}{|c|c|c|c|c|c|c|c|c|c|c|}
\hline . & $\begin{array}{l}\text { Indonesia } \\
\text { (1971) }\end{array}$ & $\begin{array}{l}\text { Philip- } \\
\text { pines } \\
(1970)\end{array}$ & $\begin{array}{l}\text { Pakistan } \\
\text { (1973-74) }\end{array}$ & $\begin{array}{l}\text { Thailand } \\
\text { (1972) }\end{array}$ & $\begin{array}{l}\text { Korea } \\
\text { (1972) }\end{array}$ & $\begin{array}{l}\text { Colombia } \\
(1971)\end{array}$ & $\begin{array}{l}\text { Costa } \\
\text { Rica } \\
(1973)\end{array}$ & $\begin{array}{l}\text { Jamaica } \\
\text { (1972) }\end{array}$ & $\begin{array}{l}\text { Kenya } \\
\text { (1972) }\end{array}$ & $\begin{array}{l}\text { Tunisia } \\
\text { (1973) }\end{array}$ \\
\hline \multicolumn{11}{|l|}{ Total import bill } \\
\hline Goods & $1,104,300$ & .210,400 & $1,370,600$ & $1,484,400$ & $2,522,000$ & 929,400 & 455,300 & 620,200 & 496,100 & 605,600 \\
\hline $\begin{array}{l}\text { Goods and non- } \\
\text { factor services }\end{array}$ & $1,578,000$ & , 349,000 & n.a. & $1,626,400$ & $2,605,700$ & $1,281,000$ & 491,400 & 721,900 & 601,800 & 724,200 \\
\hline $\begin{array}{l}\text { Medical and pharma- } \\
\text { ceutical supplies }\end{array}$ & 20,556 & 21,294 & 10,958 & 40,253 & 12,972 & 21,900 & 18,650 & 8,431 & 10,039 & 15,870 \\
\hline Alcoholic beverages & n.a. & 916 & 508 & 921 & 497 & 4,161 & 835 & 6,438 & 2,370 & 888 \\
\hline Tobacco & 2,116 & 8,321 & 555 & 28,408 & 7,377 & 3,292 & 483 & 3,633 & - & 5,100 \\
\hline Cosmetics & n.a. & n.a. & 435 & 1,942 & 256 & 219 & 5,379 & 1,869 & - & 288 \\
\hline Jewelry & n.a. & n.a. & 161 & 552 & 164 & 194 & 138 & 2,412 & - & 414 \\
\hline $\begin{array}{l}\text { Private passenger } \\
\text { cars }\end{array}$ & 23,655 & 12,209 & 8,279 & 28,369 & 12,662 & 30,749 & 9,466 & 8,431 & 16,649 & 8,656 \\
\hline $\begin{array}{l}\text { Photographic/cinema- } \\
\text { tographic equipment } \\
\text { Tovs/snorting goods }\end{array}$ & $\begin{array}{l}3,264 \\
\text { n.a. }\end{array}$ & 3,820 & n.a. & $\begin{array}{l}\text { n.a. } \\
3.116\end{array}$ & n.a. & $\begin{array}{l}\text { n.a. } \\
3.650\end{array}$ & n.a. & n.a. & $\begin{array}{l}2,181 \\
2,376\end{array}$ & n.a. \\
\hline Toys/sporting goods & n.a. & n.a. & n.a. & 3,116 & n.a. & 3,650 & n.a. & 2,488 & 2,376 & n.a. \\
\hline
\end{tabular}

'The years shown are the most recent for which data were readily available

n.a. indicates data not available.

The main conclusion suggested by these data is that in no country will total contraceptive costs amount to as much as $1 / 2$ of 1 per cent of total imports; in several, their cost will be less than $1 / 10$ of 1 per cent of total imports. Thus, few countries are likely to have difficulty financing contraceptive imports provided they give family planning a reasonably high priority in the use of their foreign exchange. However, the amounts of currency involved are far from trivial, as a comparison between Tables 1 and 3 makes clear.

The research for this study was done by Robert S. Saunders under the general direction of George B. Baldwin, in the Population Projects Department of the Bank.

\section{Fund activity continued from page 6}

\section{Developments in the world economy}

\section{A selection from}

the Fund's Annual Report, 1976

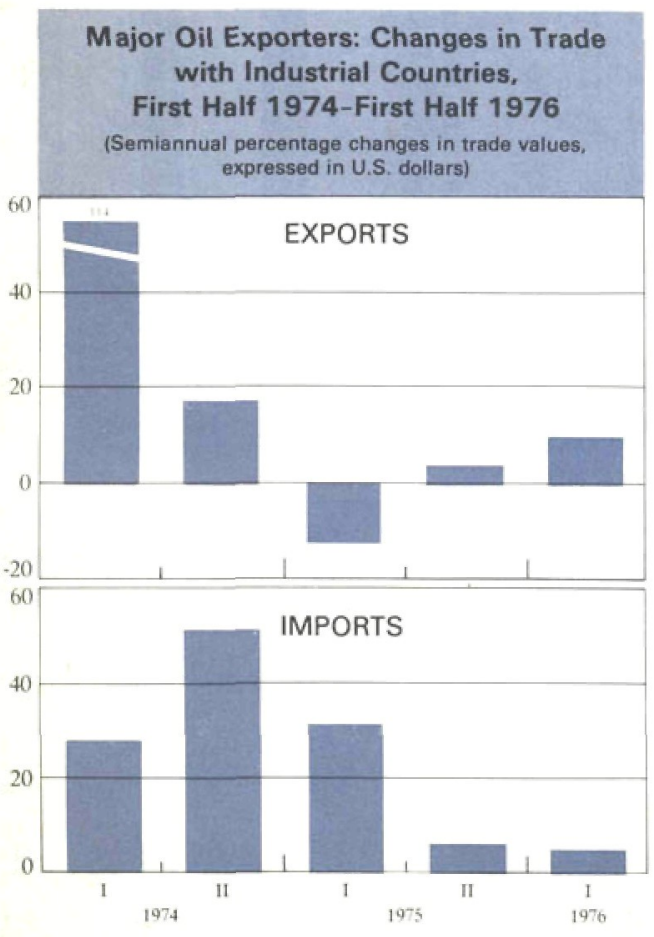

Non-Oil Primary Producing Countries: Changes in Trade with Industrial Countries, First Half 1974-First Half 1976

(Semiannuàl percentage changes in trade values.

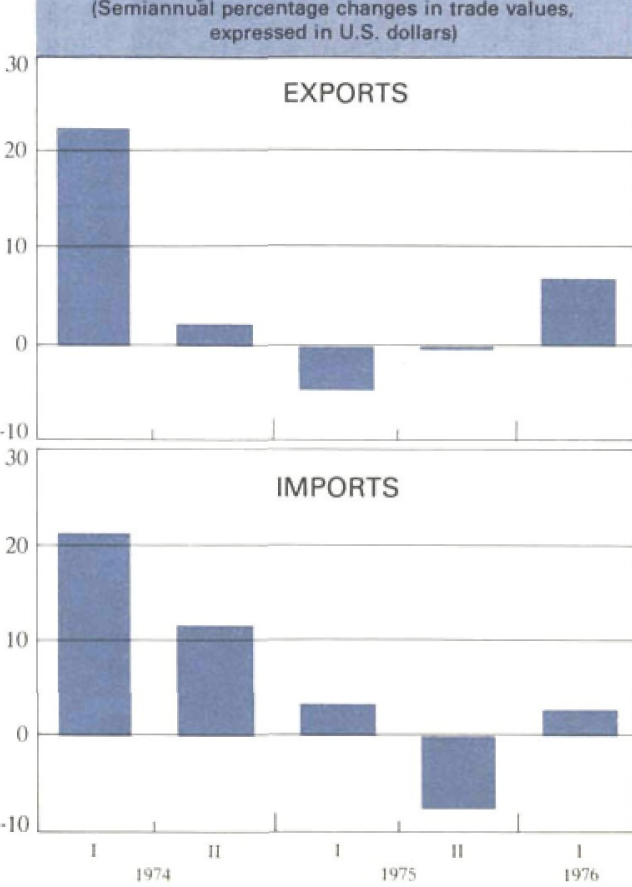

Industrial Countries: Changes in Import Volume and Export Prices, 1974-March 1976 (Quarter-to-quarter movements in per cent)'

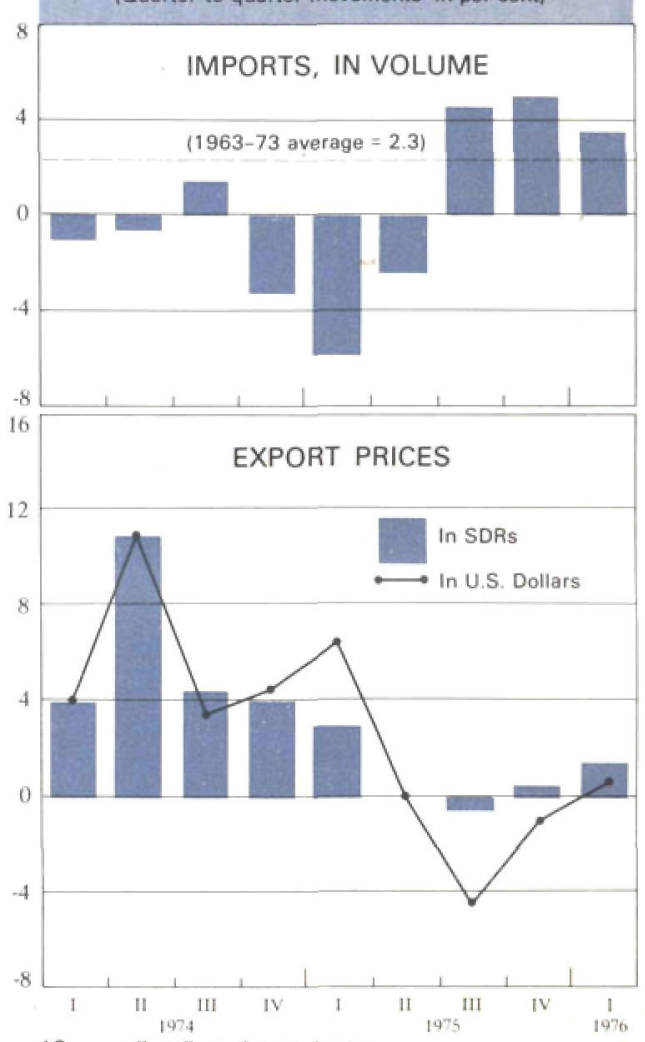

'Seasonally adjusted, actual rates. 
Summary of Payments Balances on Current Account ${ }^{1}$

(In billions of U.S. dollars)

\begin{tabular}{lcccc}
\hline & 1973 & 1974 & 1975 & $\begin{array}{c}1976 \\
\text { (Projection) }\end{array}$ \\
\hline Major oil exporters & 6 & 67 & 35 & 40 \\
Industrial countries & 12 & -10 & 19 & 3
\end{tabular}

Non-oil primary producing countries

More developed

Less developed

Total $^{3}$

$\begin{array}{rrrr}1 & -14 & -14 & -10 \\ \frac{-10}{9} & \frac{-29}{14} & \frac{-37}{3} & -32 \\ -\end{array}$

Sources: Data reported to the International Monetary Fund and Fund staff estimates.

I Goods. services, and private transfers.

Goods, senices, and privato transfers.

considerable uncertainty and should be viewed as rough orders of magnitude.

${ }^{3}$ Reflects balances of countries covered here with nonreporting countries, plus (quantitatively more important) statistical errors and asymmetries.

Growth of World Output, 1960-75

(Percentage changes in real GNP or GDP)

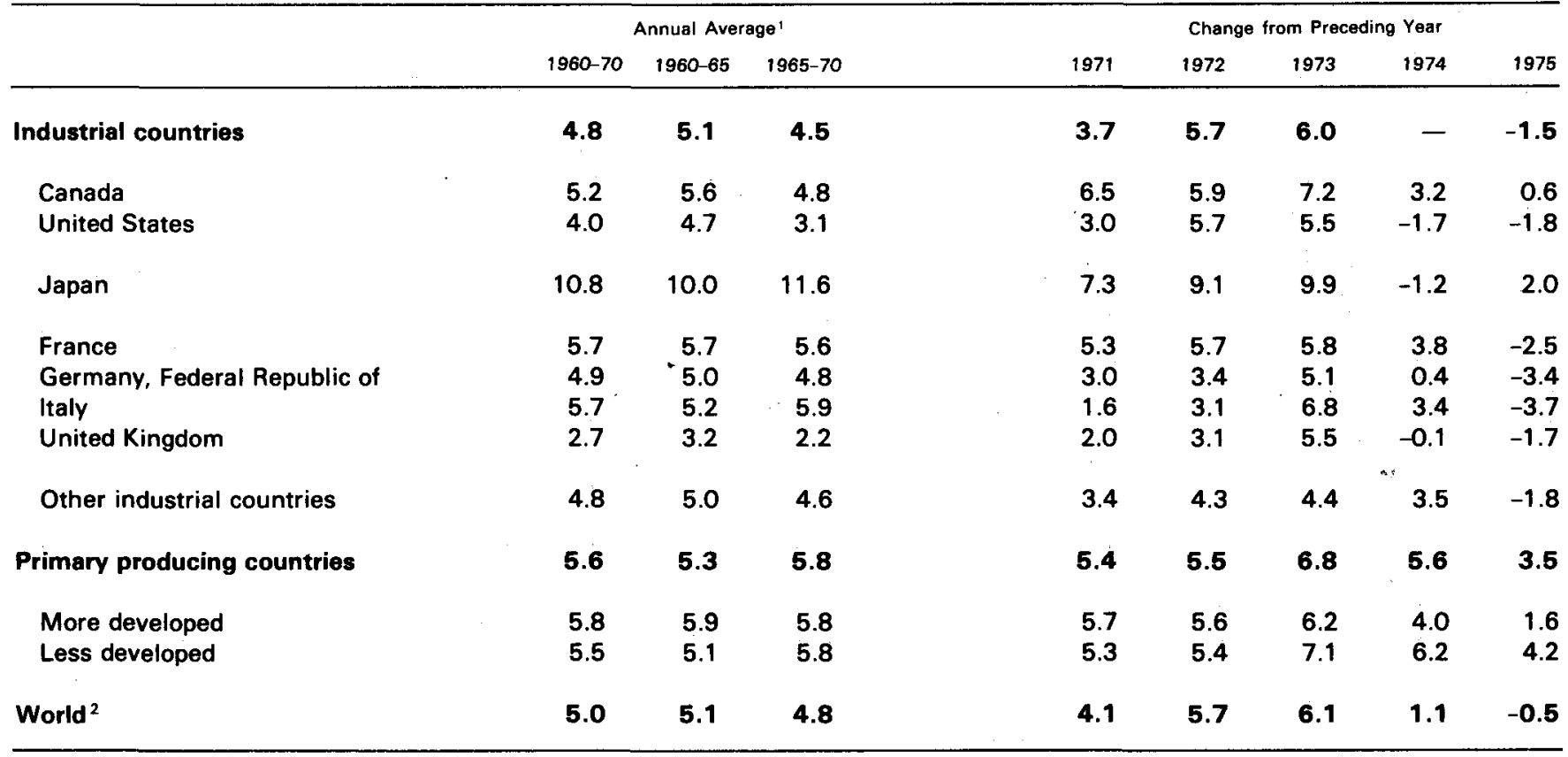

Sources: National economic reports, IMF Data Fund, secretariat of the United Nations, U.S. Agency for International Development, International Bank for Reconstruction and Development, and Fund staff estimates.

'Compound annual rates of change.

${ }^{2}$ Fund member countries plus Switzerland.

Note: The country groupings not specified in the tables and charts above are as follow:

"Other industrial countries": Austria, Belgium, Denmark, Luxembourg, the Netherlands, Norway, Sweden, and Switzerland.

The "Primary producing countries" are subdivided into "More developed" (Australia, Finland, Greece, Iceland, Ireland, Malta, New Zealand, Portugal, Romania, South Africa, Spain, Turkey, and Yugoslavia); and "Less developed," comprising Fund member countries not listed as "Industrial countries," or as being "More developed."

The less developed countries are subdivided into the "Major oil exporters" (Algeria, Bahrain, Indonesia, Iran, Iraq, Kuwait, the Libyan Arab Republic, Nigeria, Oman, Qater, Saudi Arabia, the United Arab Emirates, and Venezuela), and "Other developing countries" (or "Non-oil developing countries"). 
require further capital inflows should now be redefined. "I realize the temptation that exists to hold rates and charges on Bank loans to a minimum, but in the long run neither the interests of the Bank nor those of its borrowers, would be well served by such a policy," he added.

In his concluding remarks, $\mathrm{Mr}$. McNamara recognized the Governors' concern over this issue, and proposed a solution: "once an adequate recapitalization of the IBRD has been agreed upon, the conditions that have made this hardening necessary will have been removed, and the terms can then be moderated."

A continuation of the Bank's middlepriced Third Window-set up in 1976 for a limited term-was urged by a dozen developing country Governors as a means of easing the widening cost differential between conventional Bank lending and IDA credits. Philippine Governor Cesar E. A. Virata, also representing 19 Latin American countries, asked the Bank's member countries to "consider favorably the extension of the Bank's Third Window, as well as additional contributions to this facility," while Thailand's Amnuay Viravan felt the facility was gaining "great significance" and hoped it would become a "permanent feature of Bank activities."
Many Governors also emphasized the potential development role of the private sector in supporting a proposed $\$ 480$ million increase in the capital of the International Finance Corporation. IFC's increasing role as the Bank's primary facility for assisting semi-industrialized middle-income developing countries was stressed by Israel's Moshe Sanbar, who suggested the Corporation give specific attention to helping developing countries obtain export credit refinancing. Other Governors noted IFC's "multiplier effect" in drawing private capital to developing countries through its participation in projects.

Other important sources of concern to the Governors included increasing the disbursement rate of Bank and IDA assistance, particularly through more program and sectoral lending to, as Jamaica's Governor David H. Coore, speaking for the Caribbean island nations said, "introduce a much-needed element of speed and flexibility into the ability of the Bank to respond to the urgent needs of the developing countries."

Governors also focused on developing country trade and debt problems, with many Governors urging that the Bank take a leading role in implementing the debt rescheduling, commodity stabiliza- tion, and trade barrier-lowering concepts proposed at earlier meetings of the UNCTAD, the Paris Conference on International Economic Cooperation, and the Non-Aligned Nations as parts of the Third World's new international economic order. Several Governors spoke in favor of the representation of the People's Republic of China in the Bank and the Fund.

The Governors widely accepted a theme sounded in the opening addresses of Chairman Imady and President McNamara; that, as Mr. McNamara repeated in his closing remarks, "the primary development effort affecting a society must be made by the people of the society itself."

At the meeting's end, both $\mathrm{Mr}$. McNamara and Chairman Imady felt a common ground had been reached. "It is clear that a broad consensus has emerged," the Bank President said. "To a casual observer, it may seem that the collective views of our 127 member governments are divided. They are over details-as one would expect. They are not over fundamentals."

"No unanimity has emerged; none was expected," Chairman Imady said in closing the Thirty-First Bank Annual Meeting. "I feel that we have, however, reached a broader and deeper understanding of the problems we must face together."

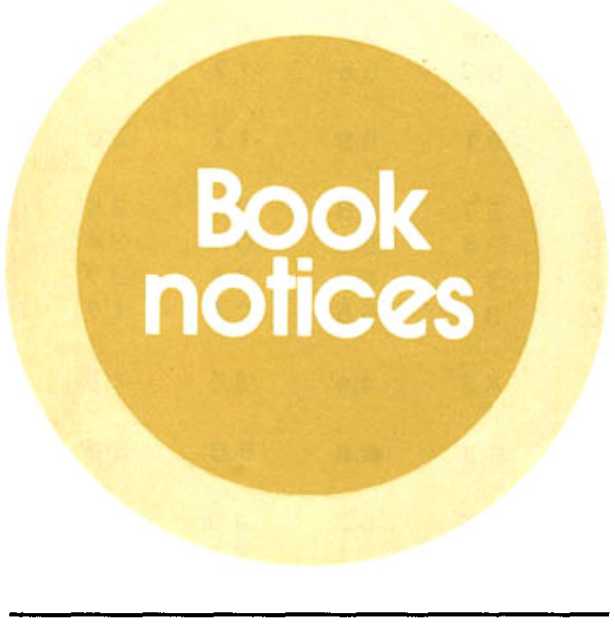

A political view

Brenner, Michael J., The Politics of International Monetary Reform-The Exchange Crisis, Cambridge, Mass., U.S.A., Ballinger Publishing Company, 1976, xiii + 144 pp., \$13.50.

The dramatic changes that have taken place in the international monetary system since 1971 have attracted the attention of political scientists, who had hitherto ne- glected international financial affairs. This book, with both its merits and its shortcomings, is a typical example of their work in this field.

Brenner's analysis is focused on the emergence of a system of managed floating rates among the major industrial countries in 1973. He shows how the national interests of the major countries, in conjunction with the institutional and ideological predelictions of the officials and politicians responsible for the relevant decisions, ruled out alternative responses to the financial difficulties facing the industrial world during this period. He gives plausible and interesting reasons for his thesis that neither freely floating rates nor a complete reorganization of international monetary institutions and rules was politically feasible at that time, nor is likely to be in the foreseeable future. His descriptive material is drawn not only from published sources but also from personal interviews with highly placed officials, bankers, and economists in the United States and Europe, as well as the International Monetary Fund and the Bank for International Settlements.

The discussions of the underlying economic causes of the breakdown of the par value system and of the pros and cons of floating exchange rates are less compelling than the analysis of political factors. For example, the author makes much of the expansion of the Eurocurrency market as a major cause of world inflation, while most economists would place the blame squarely on expansionary monetary policies; and he seems to be arguing that price elasticities in foreign trade have proved to be low, while taking into account neither the considerable time lags involved nor the fact that much of the exchange rate movement in recent years simply offset differential rates of price inflation. Mr. Brenner also fails to see that independence of monetary policy resulting from floating rates is not "illusory," as he claims, but is simply greatly reduced when rates are managed with the aim of maintaining orderly exchange markets.

This is a useful book to read for those interested in the future evolution of the international monetary system, since this will continue to be determined by political factors. However, the reader is warned that the going is made heavy by a formidable combination of a turgid style and social-scientific jargon.

Anthony Lanyi 


\section{Oil and all that}

Simha, S.L.N., and Hemalatha, D., Oil, International Payments, and Reform, Madras, India, Institute for Financial Management and Research, 1975, vii + 271 pp., Rs 50.

In the past decade, Mr. S.L.N. Simhá, an economist of considerable experience in international finance-previously with the Reserve Bank of India and now Director of the Institute for Financial Management and Research in Madras-has been exceedingly prolific, writing books entitled Gold and the International Monetary Sys. tem, International Monetary Reform, Economic and Social Change in India, Essays in Finance, and All the Bank's Men, as well as editing other volumes.

His latest work, Oil, International Payments, and Reform, written with Miss $D$. Hemalatha, is a small but comprehensive book giving some historical background and an analytical basis for understanding three major contemporary economic problems: oil and energy, the current world payments situation, and international monetary reform. The volume aims at readers interested in a general, but not superficial, survey of these problems. It achieves its purposes well, and should be of great value not only in India but throughout the world.

The portion of the book dealing with oil and energy (mainly written by Miss Hemalatha) includes a brief review of the growth of the oil industry since the nineteenth century and a longish chapter describing the impact of the 1973 oil price hikes on India's balance of payments and the strategy adopted by the Indian Government to deal with the resulting payments difficulties. There is also a short account of how the international monetary system functioned from 1945 to 1973 and a fuller exposition of the issues involved in monetary reform and the results of the negotiations conducted through 1975. The chapter on world payments gives a summary of the recent developments in the balance of payments of several industria! countries and of the prospects of their lending to the developing nations. Many statistical tables are included, and appendices contain the Committee of Twenty's Outline of Reform and describe the "snake in the tunnel" exchange rate arrangements of the European Economic Community, the swap arrangements of the central banks of the industrial countries, and the nature of the Indian exchange rate system.
Mr. Simha obviously reads extensively and has an uncanny ability to get to the heart of the matter. Hence, the wheat has been thoroughly sorted from the chaff. His personal views on many of the questions discussed-for example, that the official price of gold should have been at least doubled long ago-also show through the exposition, giving added interest to the book. The writing style is refreshingcandid, unpretentious, and, in places, almost conversational.

Margaret Garritsen de Vries

\section{Minerals, inter alia}

Smith, David N. and Louis T. Wells, Jr., Negotiating Third World Mineral Agreements: Promises as Prologue, Cambridge, Massachusetts, U.S.A., 1975 $x i i i+267$ pp., $\$ 17.50$.

This is a perceptive and objective book illuminating most of the major problems surrounding the negotiation of $\mathrm{min}$ ing agreements.

The analysis begins by describing individual characteristics of these agreements that cannot be isolated from the economic, political, administrative, and social forces that comprise the environment. No two minerals are alike nor are any two countries or corporations, and each transaction depends on the particular surrounding factors. Comparisons are drawn between past and recent trends in mining agreements.

The authors outline the various issues that negotiators must address and resolve--such as royalties, income and export taxes, equity sharing, management control, land and mineral rights, allowable deductions, depreciation, amortization and depletion, debt financing, tax incentives and holidays-and what these provisions, and the ways in which they may be implemented, may mean over the short and long term for both parties. They have classified agreements under: traditional concessions; modern concessions; production-sharing, service, and work contracts, describing the evolution from one stage to the other. The authors point out that the bargaining power of the corporation is strongest at the exploration stage and weakest at the production stage after it has invested its resources. They note that traditionally companies were unwilling to undertake the high risk of exploration without agreeing in advance on the regime that will govern exploitation should this prove feasible, a link that may in future be broken by the U.N. Mineral Exploration Revolving Fund.
Subsequent chapters cover, inter alia, revision, updating, and provisions for change in agreements, relinquishment of rights, expropriation, nationalization, investment insurance schemes, penalties and sanctions in agreements, sovereign immunity and the act of state doctrine, and avoidance of nonenforceable provisions. Abuses practiced by corporations and host countries alike are reviewed.

The authors have categorized both the successful and the not-so-successful attemps to regulate markets for raw materials. Of interest is their analysis of the necessary ingredients for a successful consortium of producing countries. The authors conclude this manual with a model agreement to illustrate and assist those commissioned with negotiating and drafting mineral agreements.

The subject matter of this book is of immense importance at this time, in light of the 1973 oil embargo and the fear of a future mineral shortage. The global mineral reserve balance is gradually shifting from the industrialized to the developing countries who do not have the means and resources to support exploration and exploitation on their own. They need the expertise and support of the multinationals. Ways and means must therefore be found to create a more stable and cooperative environment to permit the equitable and orderly development of new sources of supply. This book contributes toward an understanding of the issues facing host countries and private corporations alike and thus performs a timely public service of great value.

Rita R. Capon and David M. Sassoon

\section{Is it worth it?}

Mishan, E.J., Cost-Benefit Analysis, New York, N.Y., U.S.A., Praeger Publishers, 1976, xx + 454 pp., \$25.00, \$8.95 (paperback).

Dr. Mishan's new book is an expanded and partially revised edition of his 1971 contribution, and is offered as an introductory text on cost-benefit analysis. The topics covered include concepts of economic costs and benefits, external effects, investment criteria, and uncertainty. In addition, the volume contains several simplified case studies, a section on particular problems (such as the valuation of time savings), and a series of appendant notes which refine and expand arguments presented more simply in the main text.

The book represents a logically consistent statement of Dr. Mishan's views on 
cost-benefit analysis, many of which have appeared previously in various economic journals. The logical consistency stems from the author's careful and precise definition of cost-benefit analysis as an exercise in welfare economics designed to determine whether or not any given project leads to a potential Pareto improvement la situation in which gainers can more than compensate losers, although compensation is not actually effected). Such a definition, although firmly bedded in traditional welfare economics, does not allow for a direct consideration of interpersonal income distribution effects within the cost-benefit framework and consequently may be viewed as rather narrow. $A$ number of reasons are advanced for excluding income distribution weights (for example, their use may entail the selection of projects which do not represent a potential Pareto improvement), none of which, however, are convincing to this reviewer, especially in view of Dr. Mishan's explicit recognition that in the final analysis projects which meet the potential Pareto criterion may, nevertheless, have to be rejected if they entail adverse income distribution effects.

Whatever one's views on income distribution weights, Dr. Mishan's contribution is, nevertheless, still of interest, given the author's own demarcation of cost-benefit analysis. From this point of view, the author's sole concern with potential Pareto improvements is an advantage, since he is able to clarify a number of issues relating to the evaluation of project benefits or costs which are not adequately captured by a straightforward appeal to market prices. In particular, considerable insight is brought to bear on a variety of conceptual problems ranging from the appropriate treatment of environmental spillovers to the measurement of the cost associated with the loss of life or disablement.

Externalities aside, the author's approach involves the use of domestic prices, consumer surplus, and factor rents as the basis on which to measure costs and benefits. With regard to tradable commodities, the reader is advised, for example, to measure the benefit of additional exports by observing the domestic value of the specific goods that will be imported as a result of the additional foreign exchange thus made available. No advice, however, is offered on how this is to be achieved. In practice, some form of averaging over a number of commodities will almost certainly be required, in which event the author's recommendation amounts to the u'se of a shadow exchange rate designed to allow for approximate distortions caused by trade tariffs and other restrictions.

Once all the costs and benefits have been identified, the author recommends that the project be judged against an investment criterion based on a "normalization" procedure, which involves, among other things, establishing a common capital outlay and common terminal period for all projects under review. The objective in using this procedure is to ensure that the net-present-value criterion and the internal-rate-of-return criterion yield identical rankings of a number of alternative investment projects. Since, however, all normalized costs and benefits are compounded forward to the terminal period, the net-present-value criterion is actually a net-terminal-value criterion, and the relevant internal rate of return is that rate which equates normalized terminal benefits and the normalized capital outlay.

A numerical example involving three projects is used to illustrate that the adoption of this procedure does ensure that project ranking is independent of the choice of investment criteria. This is an interesting point: but is it necessary to use the normalization procedure in practice? For example, exactly the same ranking of the three projects can be obtained using the more usual net-present-value criterion with all costs and benefits discounted at the social yield on private investment, this being the relevant alternative use of capital in Dr. Mishan's example. If, in fact, the computationally simpler, net-presentvalue criterion is generally equivalent to any of the normalized criteria, it is not clear why these latter are to be preferred.

In summary, the author's attempt to write an introductory text on cost-benefit analysis is only partially successful: while some section's (especially that on external effects) are to be recommended, others (especially that on investment criteria) are presented more clearly elsewhere.

Lyn Squire

\section{Quo vadis EEC?}

Shlaim, Avi, and G.N. Yannopoulos, The EEC and the Mediterranean Countries, New York, N.Y., U.S.A., Cambridge University Press, 1976 , vii +350 pp., $\$ 27.50$.

Bourrinet, Jacques, La coopération économique eurafricaine, Paris, France, Presses Universitaires de France, 1976. 189 pp.

The place the European Economic Community occupies in the world is a current issue in international circles everywhere, in particular in a soul-searching Europe. Looking for a new role on the international scene, the Community decided many years ago to expand its relations with some key groups of developing countries. Opportunity was provided by the Nine's ties with its ex-colonial countries, and by the bounty of common interests created by centuries of human migrations and trade all around the European continent. These ancient relationships have been transformed into a series of freely negotiated development cooperation and trade agreements. The Lomé Convention of 1975 is the main element of this cooperation-linking the EEC to 46 African, Caribbean, and Pacific (ACP) countries. The recent Maghreb Agreements and existing or prospective agreements with several Mediterranean countries constitute the other element of the EEC's North-South connection.

The literature of the Lomé Convention is already abundant. Drawing largely on the submissions made by the Commission, the central administrative body of the EEC, to the Council of Ministers, Mr. Bourrinet's book provides a good review of the history and of the political motivations behind the Lomé Convention, followed by an analysis of the trade and financial cooperation between the two groups of countries participating in the Lomé agreement. The material is exhaustive and well presented and, in spite of some diplomatic euphemisms and concessions to the institutional rhetoric of the Community, it would provide a good source of information to students. In the concluding remarks the author mentions that the Lomé Convention may be just a step toward a new international economic order. This point can be readily conceded if it simply means to remind the reader of the need to consider the EEC-ACP relations in a broader, worldwide, and long-term perspective. But many readers would disagree with its literal implications since many of the supporters of the Lomé Convention favor regional cooperation agreements just because they are skeptical about the practica! value of universal arrangements of the type proposed at UNCTAD.

The Mediterranean Basin is the other area of the developing world on which the European Community has concentrated its efforts and established a network of preferential agreements. A review of the situation is presented by Messrs. Shlaim and Yannopoulos in their collection of brief essays. The contributions are from 16 authors of different background, although with a prevalence of academics -5 from the University of Reading-relying on diverse sources of information and there- 
fore providing a welcome variety of views on the subject. After touching on the general trade aspects with articles by M. McQueen, M.E. Kreinin, and D. Kebschull, the book deals with agricultural development (J.S. Marsh) and with immigrant labor (G.N. Yannopoulos)-the latter contribution including a vast bibliography; then it offers some country studies by G.J. Kalamotousakis on Greece, J.N. Bridge on Turkey, J.B. Donges , on Spain, and Sergio Minerbi on Israel (Portugal was left out but many references are made to it in various parts of the book). There are two regional studies: one by $R$. Aliboni on the Maghreb and one by G.V. Vassiliou on the Arab countries of the Eastern Mediterranean. The editors have dealt with the Mediterranean Basin according to a geographically precise definition which leaves out the Arab oil producing countries. Thus only the nonexplosive olive oil is mentioned at any length in the book while the OPEC is referred to only once. The book ends on a global note with an article on Mediterranean policy and the Community's external relations by S.Nenig and another one by $D$. Robertson also dealing with the Mediterranean policy in a worldwide context.

Neither the introduction nor the final notes attempt to provide a unifying theme or a single conclusion to the book, which, therefore, remains a collection of studies by scholars of different persuasions. The book was meant to outline and discuss current policy developments and the editors have fully accomplished their purpose. Each article provides the essential information on the topic it deals with, which makes the book recommended reading in the academic sector as well as in the political "think tanks" and international circles. In this way, the book provides an excellent introduction to, and whets the appetite for, a series of questions that have a strong bearing on the Community's future stance toward the Mediterranean countries. As Robertson rightly inquires at the end: what are the real costs and benefits of the EECMediterranean policy in economic and political terms? Is there any danger that the system of multiple trade agreements the Community is evolving may upset the international order so painfully achieved by means of the GATT?

The book was conceived in the domain of "low" politics, the affairs delegated by the Nine to the Community. However, an answer to the questions the book poses at the end would quickly lead to the realm of "high" politics, including defense and cultural rayonnement, jealously guarded by each of the Nine sovereign partners of the Community. For one thing, the attitudes of the Nine about the scale of the Community's effort in the Mediterranean are far from uniform. For another, the superpowers are apt to ponder more and more closely the political effects that really substantial economic cooperation can have in such a sensitive and delicately balanced area as the Mediterranean.

Vittorio Masoni

\section{Changing values}

Tribe, Laurence H., Corinne S. Schelling, and John Voss (Editors), When Values Conflict: Essays on Environmental Analysis, Discourse, and Decision, Cambridge, Mass., U.S.A., Ballinger Publishing Company, 1976, xv + 178 pp.

A cost-benefit analysis of a factory or an oil refinery has to assume a general agreement on certain basic values-how to define and therefore measure the costs and benefits of the project to the various groups affected. Otherwise, obviously, the analysis loses its usefulness as a tool to help shape policy. Today, for various reasons, basic values are changing. Profit is not seen as having so much importance for determining policy, people are no longer always sure that immediate human wants should have priority in the face of ever decreasing quantities of resources to be squandered. This book arose out of the failure of technical analysis to resolve one particular conflict involving major environmental issues, but it has a philosophical relevance to analysis and policymaking everywhere.

In 1962 the U.S. Congress authorized the construction of a major dam on the Delaware River at Tocks Island to create a 37-mile-long lake along the New JerseyPennsylvania state border. In spite of the authorization, the decision to build the dam got stuck, and is likely so to remain. Like many other decisions involving environmental issues, it proved impossible to resolve the conflict over whether there should be flood control, increased water supply, electric power, and a new recreation facility, at the expense of destroying the local communities and the scenic beauty of the area, and at the very least interfering with its ecological balance.

When Values Conflict is a collection of essays about present-day decisions involving the environment, or any other "intangible" values. These values are fundamentally unquantifiable and have never been systematically included in the technical analyses which are produced as a background to policy decisions. The book does not present us with a basis for attributing these intangibles with values which can be used on a par with costs and prices, but each chapter does provide a rigorous examination of one aspect of the problem.

The first, "Failures of Discourse," discusses what a technology responsive to intangible values would look like. The second chapter analyzes the failure of the specific technical studies relating to the Tocks Island project, and this is followed by an examination of why our society places so much value on human wants and outlines an alternative ethic. Then comes a chapter on the "rights" of the environment, which detracts from the analysis rather than adds to it. This is followed by two chapters on the political functions of analysis, and how intangible values can be incorporated into systems analysis, and two on empirical analysis.

There are problems with the book; the lack of overall cohesion leads to a lack of conclusiveness at the end. There is a tendency to romanticism which detracts from the attempt of the book to be philosophically rigorous. There is some overlapping and repetition, and some points are overemphasized-a lot is made of the difficulty of defining the values under discussion (they are described variously as "fragile," "soft," and so on). And although the language is generally clear and free of jargon, there are some lapsesa process "legitimates" an outcome, and facilities are "factored into" studies.

Nevertheless, this is a serious attempt at a systematic analysis of a problem which all of us encounter with varying degrees of urgency in our daily lives. How do we choose between the "rights" of people to change the environment, and the "rights" of the environment to remain intact, between the "rights" of man today and those of future generations? This book does not provide the answer (perhaps one is not possible in the sense that we expect), but it does provide a stimulating discussion of the issues involved.

Jos/in Landell-Mills

Toward better accounting

Davidson, Sidney, Clyde P. Stickney, and Rowal L. Weil, Inflation Accounting, New York, N.Y., U.S.A., McGraw-Hill Book Company, 1976, viii + 241 pp., \$12.50.

A significant problem that arises in the preparation of accounts is that with inflation conventional units of measurement become unstable and change in value too quickly to be useful. Although this aspect 
was recognized as early as 1936 and some attempts made to evolve new concepts of accounting to reflect the changes in the purchasing power of the units of measurement, the issue has come to receive greater attention recently.

Most of the suggested improvements in the system are still in an evolutionary form and much, however, remains to be done. Essentially, the recent proposals envisage the introduction of current value accounting or a system of general price level adjusted accounting (GPLA). The latter system has been adopted by the Financial Accounting Standards Board (U.S.A.), and this book seeks to furnish a practical guide on the new method to those engaged in the compilation, analysis, and audit of accounts. The GPLA system implies a change not merely in the units of measurement but a change covering a wide range of accounting practices, which are examined in considerable detail in the book.

The very fact that it is written primarily as a guide also severely limits the scope of the book. Presumably for this reason, it makes no attempt to provide either an indepth analysis of the conceptual issues, nor the public policy implications of the proposed system for taxation, price controls, etc. Nor does it cover any discussion of the experiences of other countries in this regard.

While the authors recognize that the ideal system would be a combination of current value accounting and GPLA (which in their view, may not be accepted in the foreseeable future), they fail to consider the implications of the recent advocacy by the Sandilands Committee (U.K.) of a system of current cost accounting which aims precisely at such a combination.

\section{A. Premchand}

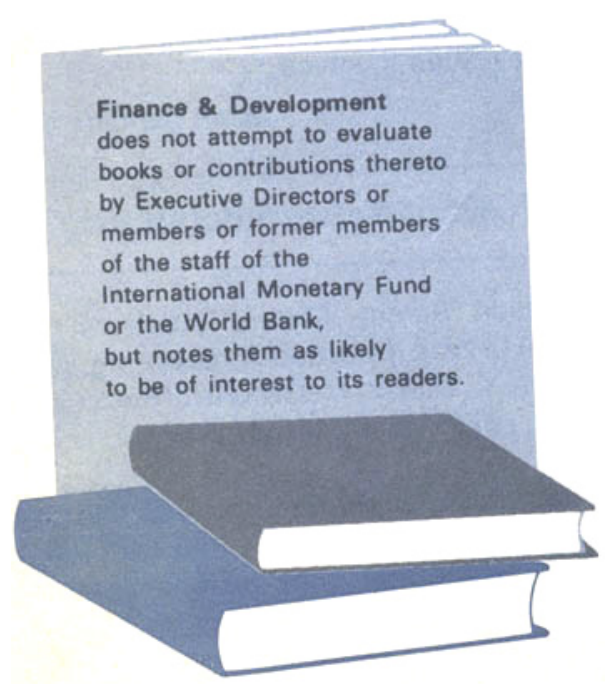

\section{Other books received}

McKenzie, George W., The Economics of the Euro-Currency System, New York, N.Y., U.S.A., Halsted Press, 141 pp., 1976, $\$ 15.95$.

Bhattacharya, Anindya K., Foreign Trade and International Development, Lexington, Mass., U.S.A., Lexington Books, 1976. $x v i+107$ pp., $\$ 13.50$.

Huq. Muhammad Shamsul, Education, Manpower and Development in South and South-East Asia, New Delhi, India, Sterling Publishers Private Limited, 1975. xvi +221 pp., Rs 50 .

Pyatt, Graham, and Erik Thorbecke, Planning Techniques for a Better Future, Washington, D.C., U.S.A., International Labour Office, 1976, ix + 91 pp., SwF 17.50 (paperback).

Hansen, Roger D., The U.S. and World Development: Agenda for Action 1976. New York, N.Y., U.S.A., Praeger Publishers, 1976, $x+222$ pp., $\$ 4.25$ (paperback).

American Enterprise Institute for Public Policy Research, The Japan-U.S. Assembly: Proceedings of a Conference on the Threat to the World Economic Order. Washington, D.C., U.S.A., 1976, xiv + 151 pp., $\$ 8.00$ (cloth) $\$ 3.50$ (paperback).

Hellinger, Stephen H., and Douglas A. Hellinger, Unemployment and the Multinationals; A Strategy for Technological Change in Latin America, Port Washington, N.Y., U.S.A., Kennikat Press Corp., 1976, 158 pp., \$12.50.

Benecke, Dieter W., Cooperación y Desarrollo; Santiago, Chile, Ediciones Nueva Universidad, 1973, 280 pp.
Benecke, Dieter W., Wolfgang Frank, Estanislao Galofré, Juan Carlos de la Jara, Carlos Mario Londoño, and Carlos Villarroel, Das Genossenschaftswesen in Lateinamerika, Munster, Fed. Rep. of Germany, Westfälische Wilhelms-Universităt, Institut für Genossenschaftswesen, 1976, 332 pp.

Simha, S.L.N., Development Banking in India, Madras, India, Institute for Financial Management and Research, 1976, xvi + 340 pp. Rs 55.

Sherbiny, Naiem A., and Mark A. Tessler (Editors), Arab Oil. Impact on the Arab Countries and Global Implications, New York, N.Y., U.S.A., Praeger Publishers, $1976, x i+327$ pp., $\$ 21.50$.

'Fontaine, Roger W., and James D. Theberge (Editors), Latin America's Now Internationalism: The End of Hemispheric Isolation, New York, N.Y., U.S.A., Praeger Publishers, 1976, xvi + 327 pp., $\$ 21.50$.

Buchholz, Edwin H., Heinz Schimmelbusch, and Manfred Wulff, Grenzen der Planung, Zürich, Switzerland, J.C.B. Mohr (Paul Siebeck), 1976, 185 pp., DM 50.

Apter, David E, and Louis Wolf Goodman (Editors), The Multinational Corporation and Social Change, New York, N.Y., U.S.A., Praeger Publishers, 1976, xiii + 234 pp., $\$ 16.50$ (cloth), $\$ 5.95$ (paperback).

Horvath, Janos, Chinese Technology Transfer to the Third World: A Grants Economy Analysis, New York, N.Y., U.S.A., Praeger Publishers, 1976, $x+101$ pp., $\$ 12.50$.
Vedavalli, R. Private Foreign Investment and Economic Development: A Case Study of Petroleum in India, Cambridge, England, Cambridge University Press, $1976, x v+219$ pp., $£ 7.00$.

This book by Miss Vedavalli traces the economic effects of direct private foreign investment in petroleum in India.

The example of India is particularly interesting; it has the second largest population in the world, and its growth in income per head has kept pace with population growth. Petroleum is fundamental for its development, and this account of the often controversial roles of the major oil companies and the government in the fields of oil exploration, production, refining and distribution in India is extensive, and uses information not previously available. The book covers the history of foreign investment in oil, and analyzes at length pricing policies regarding crude oil, petroleum products, and tanker freights. The agreements between the foreign investors and the government on joint-refinery ventures in the 1960 s are examined, as is investment in exploration, and the impact of total petroleum investment on the economy, particularly the implications on balance of payments. There is a chapter on the growth of the State sector and the role of the Soviet Union in the Indian petroleum industry. The book in its concluding chapter also analyzes the prospective role of private foreign investment in petroleum, especially in oil exploration and production in India in the post energy crisis period. 


\section{Developance}

\section{INDEX 1976}

\section{Volume 13}

\section{Articles}

Agricultural credit and the small farmer

Warren C. Baum ......................June 14

Challenging human poverty

H-Joost Polak

December

Changes within the Fund June

Cities in developing countries: 1975-2000

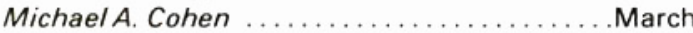

Congestion pricing - the example of Singapore

Peter L. Watson and Edward P. Holland ......... March

Criteria for policies to promote exports

Luc De Wulf and Garry Pursell .............. . June

The developing countries and access to

capital markets

M.M. Ahmad ................... December

The emerging international monetary system

H. Johannes Witteveen .............. September

Energy problems of the non-OPEC developing countries, 1974-80

Adrian Lambertini

September

The European Community's development

program

Vittorio Masoni and Joris J.C. Voorhoeve... September

The expanding Eurobond market

Carlos J. Emanuel

September

Export credit financing as a development policy

Bingu Wa Mutharika ................... June

The external debt situation of developing

countries

Thomas M. Klein .................. December

Fluctuating exchange rates and world trade

BahramNowzad ................... December

The Fund after Jamaica

J.J.Polak ........................ June

Health and the human environment

Michae/J. Sharpston

March
Incomes policy and development planning

V.V. Bhatt ..................... December

Increasing the resources of the Fund: borrowing

David Williams .................. September

Inflation and stagflation in the

international economy

Anne Romanis Braun ................. September

International reserves, money, and global inflation

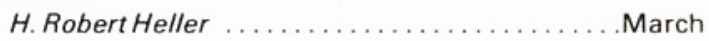

The need for a new development model

Enrique Peñalosa

March

Nontariff issues in the MTN

S.J. Anjaria

June

Oil incomes and financial policies in Iran and

Saudi Arabia

HenryE. Jakubiak and M. Taher Dajani ..... December

Oil revenues-their implication for an industrial economy

Heinz Handler December

On developing rural settlements

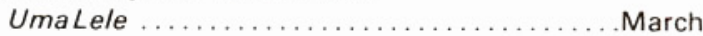

Pegging to the SDR

Andreas $S$. Gerakis

March

The problems of monetary management JohnA. Kay ........................ December

Reforming international monetary relationsan analysis

Tom de Vries .................... September

The significance of Habitat

Robert S. McNamara ................................

Structuralism and financial liberalization Vicente Galbis ..................... June

Tax havens explained Milka Casanegra de Jantscher ..............March

Toward a new framework for international commodity policy Isaiah Frank June 
The Trust Fund

Ernest Sturc

December

Uncontrolled settlements

Callisto Eneas Madavo .........................March

The World Bank - a financial appraisal: I

Eugene H. Rotberg . . . . . . . . . . . . . . . September

The World Bank - a financial appraisal: II

Eugene H. Rotberg ................... December

\section{Book Notices} Monetary Reform-The Exchange Crisis

Reviewed by Anthony Lanyi ........... December

Davidson, Sidney, Clyde P. Stickney, and

Rowal L. Weil, Inflation Accounting

Reviewed by A. Premchand ............ December

Eckholm, Erik P., Losing Ground: Environmental

Stress and World Food Prospects

Reviewed by Ralph W. Hofmeister .............. June

Eckes, Alfred E., Jr., A Search for Solvency:

Bretton Woods and the International Monetary

System, 1941-1971

Reviewed by Margaret Garritsen de Vries .......March

Falk, Richard A., A Study of Future Worlds

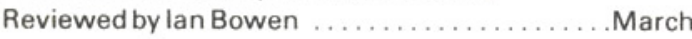

Feiwel, George R., The Intellectual Capital of Michael Kalecki

Reviewed by Andrew Crockett ......... September

Galbraith, J.K., Money-Whence it Came,

Where it Went

Reviewed by Andrew Crockett ..............June

Guillaume, Marc, Le capital et son double Reviewed by Robert Maubouché ............March

MacDougall, Donald, Studies in Political

Economy: Volume 1, The Interwar Years and the 1940 s

Reviewed by E.K. Hawkins ................March

MacDougall, Donald, Studies in Political

Economy: Volume II, International Trade and Domestic Economic Policy

Reviewed by E.K. Hawkins . ........................

Meister, Albert, L'inflation créatrice

Reviewed by lan Bowen ..................... June

Mishan, E.J., Cost-Benefit Analysis

Reviewed by Lyn Squire ... . . . . . . . . . . December

Moreau-Neret, O. and others, Les bourses de valeurs dans le monde

Reviewed by Bahram Nowzad ................... June

Sen, Sudhir, Reaping the Green Revolution Reviewed by lan Bowen ..................March

Sen, Sudhir, A Richer Harvest

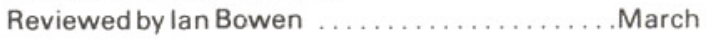

Shlaim, Avi and G.N. Yannopoulos, The EEC and the Mediterranean Countries

Reviewed by Vittorio Masoni ....... . . . . . . December

Shonfield, Andrew (editor), International Economic Relations of the Western World: 1959-1971, Vol. 1: Politics and Trade

Reviewed by lan Bowen .............. September

Simha, S.L.N. and D. Hemalatha, Oil,

International Payments, and Reform

Reviewed by Margaret Garritsen de Vries... December

Singer, H.W., The Strategy of International

Development: Essays in the Economics of Backwardness

Reviewed by Joseph Wood . . . . . . . . . . . . . June

Smith, David N. and Louis T. Wells, Jr., Negotiating

Third World Mineral Agreements: Promises as Prologue

Reviewed by Rita R. Capon and

David M. Sassoon ..............................

Sommerlad, E. Lloyd, National Communication Systems: Some Policy Issues and Options

Reviewed by Shuja Nawaz ............. September

Strange, Susan, International Economic Relations of the Western World, 1959-1971, Volume 2: International Monetary Relations

Reviewed by Margaret Garritsen de Vries... September

Tribe, Laurence H., Corinne S. Schelling, and John Voss (editors), When Values Conflict: Essays on Environmental Analysis, Discourse, and Decision

Reviewed by Joslin Landell-Mills . . . . . . . . . December

Vedavalli, R., Private Foreign Investment and Economic Development: A Case Study of

Petroleum in India ................. December 


\section{NEW BOOKS}

\section{from the World Bank and The Johns Hopkins University Press}

\section{The Tropics and Economic Development}

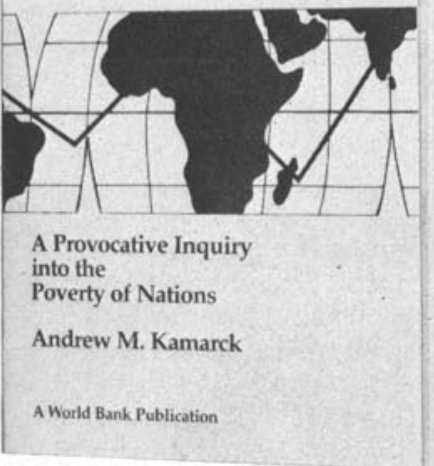

\section{The Tropics and Economic Development}

Andrew M. Kamarck

Why has the developing world lagged in the world-wide process of modern economic growth? The author suggests that prevalent theories addressing this question often disregard the facts and neglect the real problems of Third World countries.

Within the latitudes of the Tropics lies much of the less developed world, with few industrialized areas and no wholly developed countries. This book advances the hypothesis that countries in these areas have not developed apace by the very fact of their location. Certain effects of climate in tropical areas have hindered agriculture, handicapped mineral exploration, and made the population less vigorous through disease and, possibly, the direct physiological impact of temperature and humidity.

In addition to presenting a clear, nontechnical examination of current relevant research from many disciplines, including economics, agronomy, pharmacology, and mineralogy, the author discusses important areas where more research-and more funding for it-is urgently needed.

128 pages; maps; index. Cloth $\$ 7.50$ ( $£ 5.25$ ); paper $\$ 3.00$ ( $£ 2.10)$.

\section{Village Water Supply: \\ Economics and Policy in the Developing World}

Robert J. Saunders and Jeremy J. Warford

The great majority of persons in rural areas of the developing world do not have access to a safe and convenient source of water, and where this is available, acceptable sewage disposal facilities are normally lacking. The authors examine a wide range of factors-physical, social, and economic - that are involved in improving the adequacy of water supply and sanitation in the coming years.

Among the principal topics covered in detail are: the character and extent of the problems connected with water supply and sanitation; the goal of improved health, with specific reference to the relation between water supply and water-borne disease, on the one hand, and social and economic activity on the other; the effects of improved water supply and sanitation on productivity, incomes, rural-to-urban migration, and overall development; problems of, and strategies for, program planning and administration; the special problems of operation and maintenance; and the importance of recovering program costs from beneficiaries. The final chapter contains a summary of the findings of the study and lists a number of recommendations for improving rural water supply and sanitation.

296 pages; index; bibliography. Cloth $\$ 15.00$ ( $(10.50)$; paper $\$ 6.00$ ( $£ 4.20)$.

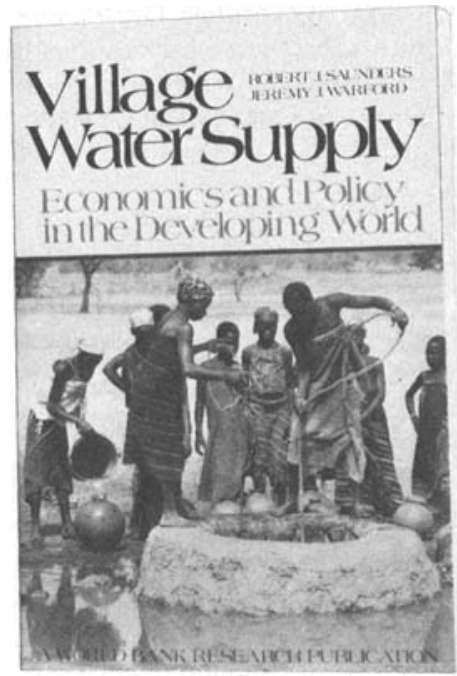

\section{World Tables1976}

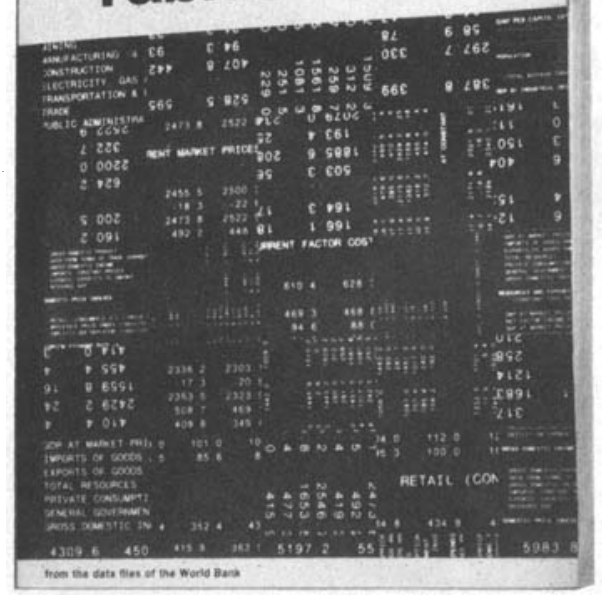

\section{World Tables 1976}

World Tables 1976 contains one of the most complete collections ever made available of economic time series data and social indicators for most developing and many industrialized countries of the world. The nearly 250 tables, covering more than 140 countries, are divided into four series.

Series 1. National Accounts and Prices. Data for both developing and industrialized countries-for 1950, 1955, and, yearly, 1960-73-on principal economic measurements. Also shown are annual growth rates and percentages for the periods $1950-60,1960-73$, and 1965-73.

Series II. Balance of Payments and Central Government Finance. Data for developing countries for the years 1967-73 on principal economic measurements. Also shown are percentages of related measurements for 1967 and 1973.

Series III. Comparative Economic Data. Comparative derived data for countries grouped as developing, industrialized, and centrally planned, with average figures for each income group and geographic region and for oil producers.

Series IV. Social Indicators. Social indicators, 1960 and 1970, for countries grouped by income, with adjusted averages for each income group and geographic region and for industrialized countries.

560 pages; index of countries covered; translation of headings into French and Spanish; glossary. Cloth $\$ 22.50$ ( $\boldsymbol{f 1 5 . 7 5 )}$; paper $\$ 8.95$ (f6.25) 


\section{International Monetary Fund publications}

\section{Periodicals}

Balance of Payments Yearbook. Monthly, loose-leaf, US\$7.50 a volume; binder available for US\$3.50. Annual, clothbound, US\$6.00.

Direction of Trade. Monthly, with annual supplement. US\$10.00 a year.

International Financial Statistics. Monthly, with annual supplement. US\$20.00 a year.

Staff Papers. Three times a year. US $\$ 6.00$ a year.

University libraries, faculty members, and students may obtain the four subscription publications listed above at the reduced rates of US $\$ 12.00$ for the four publications or US\$5.00 for International Financial Statistics and US\$3.00 each for the other publications.
IMF Survey. 16 pages, twice monthly (once in December). Editions offered in English, French (Bulletin du FMI), and Spanish (Boletín del FMI). Annual rates for delivery: US\$5.00 in Canada, Mexico, and United States; US\$10.00 in Central and South America; US\$12.00 in all other areas.

\section{Tape subscriptions}

Series from International Financial Statistics, from Direction of Trade, and from the Balance of Payments Yearbook are available on tape for computer users, at a price of US\$1,000.00 a year for each title (US $\$ 300.00$ to universities). Each subscription includes 12 monthly tapes and the book version.

Advice on payment in currencies other than the U.S. dollar will be given upon receipt of order. Airmail subscription rates are available upon request. Address inquiries to The Secretary, International Monetary Fund, Washington, D.C. 20431, U.S.A.

\section{Books from the Fund}

Instruments of Monetary Policy in the United States: The Role of the Federal Reserve System. Ralph A. Young. 1973. US\$1.25.

Membership and Nonmembership in the International Monetary Fund: A Study in International Law and Organization. Joseph Gold. 1974. US\$10.00.

Voting and Decisions in the International Monetary Fund: An Essay on the Law and Practice of the Fund. Joseph Gold. 1972. US\$6.50.

The Stand-By Arrangements of the International Monetary Fund: $A$ Commentary on Their Formal, Legal, and Financial Aspects. Joseph Gold. 1970. US\$4.00

International Reserves: Needs and Availability. Proceedings, IMF Seminar. 1970 . US\$6.00.

Central Banking Legislation: A Collection of Central Bank, Monetary and Banking Laws. Hans Aufricht. Vol. II, Europe, 1967. US\$10.00. (Vol. I is out of print.)

\section{Surveys of African Economies}

Vol. 1. Cameroon, Central African Republic, Chad, Congo (Brazzaville), and Gabon. 1968.
Vol. 2. Kenya, Tanzania, Uganda, and Somalia. 1969.

Vol. 3. Dahomey, Ivory Coast, Mauritania, Niger, Senegal, Togo, and Upper Volta. 1970.

Vol: 4. Democratic Republic of Congo (Zaïre), Malagasy Republic, Malawi, Mauritius, and Zambia. 1971.

Vol. 5. Botswana, Lesotho, Swaziland, Burundi, Equatorial Guinea, and Rwanda. 1973.

Vol. 6. The Gambia, Ghana, Liberia, Nigeria, and Sierra Leone. 1975.

Vols. 2, 4, 5, and 6 also available in French. US\$5.00 a volume (US\$2.50 a volume to university libraries, faculty members, and students).

The International Monetary Fund, 1945-1965: Twenty Years of International Monetary Cooperation. (3 vols.). J. Keith Horsefield and others. 1969 . US $\$ 12.50$ a set (US\$5.00 a volume).

The Fund Agreement in the Courts. Joseph Gold. 1962. US\$3.50.

International Monetary Problems, 1957-1963: Selected Speeches of Per Jacobsson. 1964. US\$2.50.

Advice on payment in currencies other than the U.S. dollar will be given upon receipt of order. Airmail subscription rates are available upon request. Address inquiries to The Secretary, International Monetary Fund, Washington, D.C. 20431, U.S.A. 